\title{
Law's Signal: A Cueing Theory of Law in Market Transition
}

Robert B. Ahdieh

Texas A\&M University School of Law, ahdieh@law.tamu.edu

Follow this and additional works at: https://scholarship.law.tamu.edu/facscholar

Part of the Antitrust and Trade Regulation Commons, Business Organizations Law Commons, Comparative and Foreign Law Commons, Law and Economics Commons, and the Securities Law Commons

\section{Recommended Citation}

Robert B. Ahdieh, Law's Signal: A Cueing Theory of Law in Market Transition, 77 S. Cal. L. Rev. 215 (2004). Available at: https://scholarship.law.tamu.edu/facscholar/1199

This Article is brought to you for free and open access by Texas A\&M Law Scholarship. It has been accepted for inclusion in Faculty Scholarship by an authorized administrator of Texas A\&M Law Scholarship. For more information, please contact aretteen@law.tamu.edu. 


\title{
ARTICLES
}

\section{LAW'S SIGNAL: A CUEING THEORY OF LAW IN MARKET TRANSITION}

\author{
ROBERT B. AHDIEH ${ }^{*}$
}

\begin{abstract}
Securities markets are commonly assumed to spring forth at the intersection of an adequate supply of, and a healthy demand for, investment capital. In recent years, however, seemingly failed market transitions-the failure of new markets to emerge and of existing markets to evolve-have called this assumption into question. From the developed economies of Germany and Japan to the developing countries of central and eastern Europe, securities markets have exhibited some inability to take root. The failure of U.S. securities markets, and particularly the New York Stock Exchange, to make greater use of computerized trading, communications, and processing technologies, meanwhile, seems to suggest some market resistance to technological modernization. In light of this pattern, one must wonder: How are strong markets created and maintained, and what might be law's role in this process?

This Article attempts to articulate a model for understanding the needs of efficient market transition and the resulting role of law in that

* Associate Professor of Law, Emory University School of Law; A.B. 1994, Princeton University; J.D. 1997, Yale Law School. 1 am extraordinarily grateful to my colleagues Anita Bernstein, Bill Buzbee, Bill Carney, Marc Miller, Polly Price, Robert Schapiro, and George Shepherd for their time and patience with my thoughts, excerpts, and drafts. Many thanks also to Amitai Aviram. Lisa Bernstein, Nicholas Economides, Philip Hamburger, Tarun Khanna, Michael Klausner, Mark Klock, Richard McAdams, Charles Noussair, Tom Remington, Roberta Romano, Kent Syverud, Fred Tung, Bert Westbrook, and workshop participants at the University of Chicago and the Southeastern Association of Law Schools annual meeting. I also thank the Emory Law School library staff and my research assistants for their tireless assistance.
\end{abstract}


process. Specifically, it suggests a "cueing" function for law in market transition. Grounded in largely ignored lessons of game theory and in the microeconomic analysis of so-called network effects, cueing theory identifies the coordination of market participants' expectations as law's central role in market transition. Building on recent legal literature on private regulation, social norms, and the expressive function of law, this theory suggests that in securities market transition-whether it be market creation in central and eastern Europe or market restructuring in the United States-law primarily serves to convene, encourage, inform, and facilitate.

A cueing role for law constitutes an important extension of traditional conceptions of what law does, particularly in securities regulation, but in other areas as well. Regulatory cues are neither coercive nor outcome determinative and involve a close intertwining of public and private regulation. The exceptional character of law in this context, and the recent growth in areas where regulatory cues might have fruitful application, may explain why such a role has not previously been analyzed. Yet in securities markets and other industries exhibiting network economies-from electricity transmission and interstate transportation to telecommunications and the Internet-a cueing function for law may be central to efficient transition. It may explain much of why "law matters" in the modern economy.

\section{TABLE OF CONTENTS}

ABSTRACT

TABLE OF CONTENTS

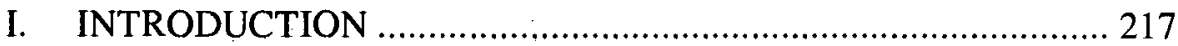

II. THE LIMITS OF SPONTANEOUS TRANSITION ...................... 221

A. TRANSITION FAILURES IN SECURITIES MARKET CREATION AND RESTRUCTURING ..................................................... 221

B. THE ECONOMICS OF INEFFICIENT MARKET TRANSITION........ 223

III. A GAME THEORY OF MARKET TRANSITION ........................ 229

A. COORDINATING EXPECTATIONS IN TRANSITION ................... 229

B. THE COORDINATION GAME OF MARKET TRANSITION............ 233

C. PATHS AND PITFALlS OF EFFECTIVE COORDINATION ............ 239

IV. TOWARD A CUEING THEORY OF LAW

IN MARKET TRANSITION ..................................................... 245

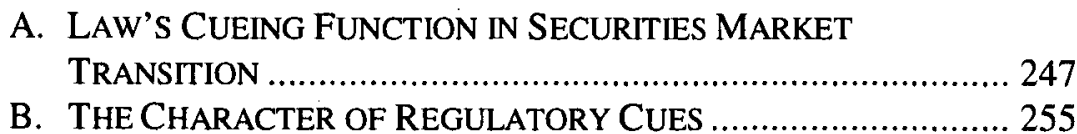


1. Cues as Nondirective and Nonoutcome Determinative

Law

2. Cues as Expressive Law ........................................... 259

3. The Public/Private Distinction in Regulatory Cues .......... 261

V. FINDING THE CUES IN SECURITIES LAW:

MARKET STRUCTURE, THE NATIONAL MARKET SYSTEM,

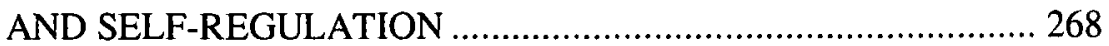

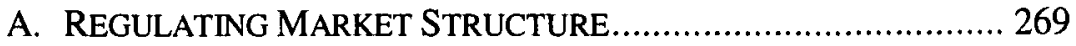

B. REGULATORY CUEING AND THE NATIONAL MARKET SYSTEM.

1. History of the National Market System.

2. Regulatory Cues in the National Market System Project.. 279

C. SECURTIES MARKET SELF-REGULATION 284

VI. APPLICATIONS AND IMPLICATIONS OF REGULATORY CUES IN SECURITIES MARKET TRANSITION 289

A. CONSOLIDATION VERSUS FRAGMENTATION ........................ 289

B. AUCTION VERSUS DEALER MARKETS................................ 295

C. CONTINUOUS VERSUS PERIODIC TRADING ........................... 298

D. SECURITIES MARKETS VERSUS BANKS:

FIRST QUESTIONS OF MARKET STRUCTURE......................... 300

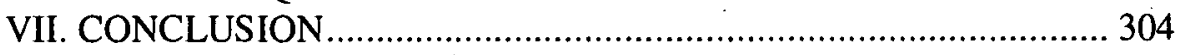

\section{INTRODUCTION}

Markets are often assumed to emerge spontaneously from the confluence of relevant supply and demand. At least in the case of public securities markets, however, this confidence in markets' capacity to spontaneously make markets may be unjustified. Perhaps the clearest basis for such doubt is the continued absence of strong securities markets in the nations of the former Soviet bloc. Notwithstanding more than a decade of effort to lay the foundation for vibrant and reliable capital markets, few of the newly independent states have made the transition to public securities markets as the dominant source of corporate finance. ${ }^{1}$

Even in developed economies, securities markets have not always emerged as expected. Germany is only the most familiar example of this pattern. ${ }^{2}$ Existing securities markets, meanwhile, have often resisted transition to modernized, efficient market forms. The securities markets of

1. See, e.g., Bernard Black, Reinier Kraakman \& Anna Tarassova, Russian Privatization and Corporate Governance: What Went Wrong?, 52 STAN. L. REv. 1731, 1733 (2000).

2. See John C. Coffee, Jr., The Rise of Dispersed Ownership: The Roles of Law and the State in the Separation of Ownership and Control, 111 YALE L.J. 1, 7 (2001). 
the United States, despite their emulation across the globe, have thus been criticized for their failure to adopt, and adapt to, modern technologies ${ }^{3}$ and to achieve a greater degree of intermarket linkage ${ }^{4}$ and information transparency. ${ }^{5}$

1 have previously articulated a network theory of securities markets that helps to explain this pattern of inefficient market transition. ${ }^{6}$ Specifically, 1 argued that network effects characterize the basic functions of securities markets: the provision of market liquidity and the facilitation of efficient price discovery. Such network effects-which many have termed "network externalities," an appellation overly dismissive of the prospect of internalization-cause the value of a given securities market, and the securities traded on it, to increase with each additional trader, issuer, or other market participant. The central benefits of securities markets, in this view, follow from their network character.

Yet, paradoxically, securities markets' network character may stymie their efficient creation and restructuring. Investment in new markets and technologies may be suboptimal; relatively inefficient markets may predominate, and market participation may be depressed, among other results. $^{7}$ Contrary to the assumption of many scholars and regulators, efficient markets may not emerge spontaneously. Rather, the creation of new securities markets across Europe, and both the adoption of new trading technologies and the achievement of efficient market interlinkage in the United States, may require a direct role for law in market structure and

3. See Morris Mendelson \& Junius W. Peake, Intermediaries' or Investors': Whose Market Is It Anyway?, 19 J. CORP. L. 443, 447 (1994). See also Dale Arthur Oesterle, Donald Arthur Winslow \& Seth C. Anderson, The New York Stock Exchange and Its Out Moded Specialist System: Can the Exchange Innovate to Survive?, 17 J. CORP. L. 223, 226 (1992) ("In this changing environment, the NYSE generated very few significant innovations in trading procedures, membership policies, or product listing.") (internal footnote omitted); infra note 18.

4. See Jonathan R. Macey \& David D. Haddock, Shirking at the SEC: The Failure of the National Market System, 1985 U. ILL. L. REV. 315, 332 (1985); Joel Seligman, Rethinking Securities Markets: The SEC Advisory Committee on Market Information and the Future of the National Market System, 57 BuS. LAw. 637, 651-52 (2002).

5. See Seligman, supra note 4 , at 670.

6. See Robert B. Ahdieh, Making Markets: Network Effects and the Role of Law in the Creation of Strong Securities Markets, 76 S. CAL. L. REV. 277 (2003). As used herein, "transition" is intended to encompass both the creation of new markets (i.e., the shift from alternative or nonexistent systems of corporate finance to reliance on public securities markets) and the technological and structural evolution of existing securities markets.

7. See id. at 314-21. See also Carmine Di Noia, Competition and Integration Among Stock Exchanges in Europe: Network Effects, Implicit Mergers and Remote Access, 7 EUR. FIN. MGMT. 39, $42-43$ (2001). 
design. ${ }^{8}$ Yet what is the nature of this role? How might law help facilitate market transition?

The network character of the obstacles to efficient market transition requires law to play a role distinct from the demarcation of property rights, the enforcement of contracts, and similar background institutional functions, which are more widely acknowledged. ${ }^{9}$ Instead, law must help coordinate the expectations of securities market participants to induce efficient market entry, as well as the creation and utilization of new market systems and technologies. In the creation of new markets in central and eastern Europe, for example, the role of law may be to convene a working group of active brokers and dealers, to disseminate technical or financial information, or to direct public investment to fledgling markets. ${ }^{10}$

In this Article, I attempt to elucidate and conceptualize this unfamiliar role for law. Legal scholars have often looked to the Prisoner's Dilemma to understand law's social and economic functions. In this view, law constrains individually preferred strategies in the service of socially, and ultimately even individually, optimal outcomes. Such a role is correctly rejected in securities market transition.

Instead, law's role in market transition must be informational, instructive, and facilitative in nature. Better insight into law's role can therefore be found in often overlooked, yet omnipresent coordination games, in which aligned interests and a resulting preference for cooperation - the hallmarks of network environments, including not only securities markets, but other standard-driven industries from electricity transmission to instant messaging-are the dominant features. ${ }^{11}$

Considering three forums of securities market transition from a coordination game perspective-the creation of new markets, the adoption of new trading technologies in existing markets, and the creation of linkages among competing markets-I describe the nature of the game of

8. See infra Part II.B. For a general argument that the state must play a central role in market transition, see Alice H. AMSDEN, JACEK KOCHANOWICZ \& LANCE TAYLOR, THE MARKET MEETS ITS MATCH: RESTRUCTUR ING THE ECONOMIES OF EASTERN EUROPE (1998).

9. See Ahdieh, supra note 6, at 279-80.

10. See infra Part IV.A.

11. In its most basic form, the coordination game dynamic is manifest in the so-called Meeting Place game. See Thomas C. SChelling, The STR ATEgy OF Conflict 54-55 (2d ed. 1980). In this fanciful case, a husband and wife are separated in a department store without a prearranged meeting place and face the dilemma of where to meet. Their interests and incentives are aligned, but they lack the necessary information-specifically, accurate expectations of one another-to find each other and solve the game. In the real world, a familiar Meeting Place game arises from approaching drivers' choice of which side of the road to drive on. 
securities market transition and introduce a theory of law's role in market transition. ${ }^{12}$ Specifically, I draw on Thomas Schelling's often-cited but little-understood concept of "focal points" to propose a "cueing theory" of law in market transition. Not grounded in law's sanction or coercive functions, but rather in a variety of instructional, informational, and participatory mechanisms, this conception of law's role in securities market transition emphasizes its facilitation, rather than dictation, of effective private coordination.

Part II describes the aforementioned pattern of inefficient securities market transitions and outlines the network obstacles that may help explain this pattern. Part III proposes a game theory of market transition, identifying coordinated expectations as the critical need, looking to coordination games to characterize this need, and suggesting the limited efficacy of traditional sources of coordination in securities market transition.

Part IV posits "regulatory cues" as an alternative mechanism of coordination, identifying the functions, form, and exceptional nature of such cues, which are neither coercive nor outcome determinative, which are directed to coordination rather than cooperation, and which are as closely intertwined with private as with public regulation. A cueing theory of law in market transition, I suggest, expands on the existing scholarly literature on private regulation, social norms, and expressive law.

Parts V and VI, finally, bring the proposed cueing theory to bear on the regulation of existing and potential securities markets. I suggest the need to reassess the scope of securities regulation, as it is commonly understood, reconsider widespread assumptions concerning the failure of the National Market System project in the United States, and incorporate the lessons of cueing theory into regulation of the fragmentation of the securities markets, of the choice of auction versus dealer markets, and of the preliminary determination to rely on either banks or public securities markets for corporate finance. ${ }^{13}$ The latter issues are among the central questions facing existing and emerging securities markets today.

12. Besides the exemplary transitions mentioned, I will also discuss the SEC's efforts to create a National Market System in the early 1970s, the only example of any significant U.S. regulatory effort to facilitate efficient transition, as well as recent developments in the Russian securities markets.

13. As the enumerated examples suggest, the implications of a network theory of inefficient market transition run largely to issues of market microstructure-the institutional and organizational forms of market trading, communication, settlement, and related activities. Other aspects of securities market form also have network dimensions, however, including the preliminary choice of a bankdominated or public securities market system of corporate finance. See infra Part VI.D. For this reason, 1 use the term "market structure" to capture the scope of application of the previously articulated 
The Article concludes with a notation of the exemplary, rather than exclusive, nature of the securities market analysis herein. A cueing function for law has wide application beyond the securities markets, most immediately in areas similarly pervaded by network effects. Law's present and potential roles in telephony, high definition television ("HDTV"), electricity transmission, and the Internet therefore warrant analysis, and perhaps adjustment, under the proposed cueing theory. Beyond network industries, regulatory cueing may even have a role to play in the regulation of closed markets and monopolies generally.

\section{THE LIMITS OF SPONTANEOUS TRANSITION}

Transition-in the form of both market creation and market restructuring-may well be the most significant challenge facing securities markets today. Whether it is the rise of securities markets in the bankdominated economies of Germany and Japan, the halting emergence of new markets in central and eastern Europe, or the growing role of alternative trading systems ("ATSs") in the United States, issues of market transition stand at the heart of the challenges facing contemporary securities markets.

Yet how does such transition occur in the securities markets? Given limited scholarly efforts to identify and conceptualize the mechanisms of transition, and limited regulatory efforts to draw on such mechanisms or otherwise facilitate market transition, one might assume that transition is entirely spontaneous. ${ }^{14}$ Conventional wisdom seems to suggest that "markets make markets." Yet recent evidence suggests there may be reason for doubt. After assessing these grounds for doubt, this part outlines a microeconomic theory of such market "failure," which I have termed a network theory of securities market transition.

\section{A. TRansition FaIlures IN SECURTties Market Creation AND RESTRUCTURING}

Over the last decade, securities market scholars increasingly have puzzled over the failure of strong securities markets to emerge in the bankdominated economies of Germany and Japan, notwithstanding the presumed greater efficiency of a securities-market-oriented separation of ownership and control. ${ }^{15}$ In the face of such resistance, alternative theories have posited that strong securities markets are incompatible with social

network theory of inefficient market transition and of the presently proposed cueing theory with respect to such inefficiency and how it can be overcome.

14. See Ahdieh, supra note 6, at 279-81, 322 n.203.

15. See Coffee, supra note 2, at 3-8. 
democracy, that securities markets require strong protections of minority shareholders, and that regulatory restraint by public authorities is necessary to facilitate the vibrant private regulation needed for strong securities markets. ${ }^{16}$

More recently, similar concerns have been raised in central and eastern Europe. Notwithstanding more than a decade of effort laying a foundation for efficient capital markets, as well as strong demand for investment capital and a substantial pool of institutional funds available for investment in emerging markets, why have strong securities markets not emerged in the post-Soviet space? In securities markets, as elsewhere, the "end of history"17 - a dramatic reorientation to western political and economic models-has begun to look far less conclusive than once thought.

Even in the United States, high praise for the securities markets' successes has not drowned out persistent criticisms. Most significant is the criticism of the failure of dominant U.S. markets to keep pace with modern technological innovations, including, particularly, the dramatic telecommunications and computer processing advances of recent years. ${ }^{18}$ The New York Stock Exchange ("NYSE") has thus been criticized for its continued use of outdated and inefficient trading mechanisms and for a pattern of adopting technologies previously developed by others, rather than creating innovations of its own. ${ }^{19}$ What technological innovation there is in the U.S. securities markets is being driven by small-scale electronic communications networks ("ECNs") and other ATSs; consequently, this innovation does not impact the vast proportion of market trading activity.

16. See id.

17. See Francis FuKUYAma, The END OF History and the last MAN, at xi (1992) (arguing that liberal democracy, as a system of government, may constitute the "end point of mankind's ideological evolution" and "final form of human government," and, as such, constitutes the "end of history").

18. See Oesterle et al., supra note 3, at 226. See also Thomas H. McInish \& Robert A. Wood, Competition, Fragmentation, and Market Quality, in THE INDUSTRIAL ORGANIZATION AND REGULATION OF THE SECURITIES INDUSTRY 63, 84-85 (Andrew W. Lo ed., 1996) ("[A]ll of the extensive technological innovations in market mechanisms during the past thirty years have been initiated by the regional exchanges, the third-market dealers, and the proprietary trading systems (PTS), with the NYSE matching innovations to avoid loss of market share... Dominant competitors have little incentive to innovate.") (internal footnote omitted). Cf. Gerald T. Nowak, Note, A Failure of Communication: An Argument for the Closing of the NYSE Floor, 26 U. MICH. J.L. REFORM 485, 524 n.192 (1993) (noting that the NYSE might become a museum of bygone technology, while other exchanges, including the Tokyo, London, and Toronto exchanges, come to dominate international securities trading).

19. See McInish \& Wood, supra note 18 , at $63,84-85$; Oesterle et al., supra note 3, at 226-27. 
U.S. exchanges and trading systems ${ }^{20}$ have faced related criticism for their failure to develop efficient mechanisms for the general dissemination of quote data and for cross market trade. ${ }^{21}$ Such information transparency and the cost-effective potential for execution across markets have long been recognized as important sources of efficiency gains in securities trading, ${ }^{22}$ yet are still only imperfectly achieved in U.S. securities markets. If anything, recent trends point toward growing fragmentation of the markets. ${ }^{23}$

One can find examples of absent or incomplete securities market transition, then, in the processes of creating new securities markets, adopting new trading technologies, and hinking competing markets. In each of these circumstances, to which I return throughout this analysis, securities markets may require some intervention to effectively adapt to changing, or changed, conditions.

\section{B. THE ECONOMICS OF INEFFICIENT MARKET TRANSITION}

A variety of reasons, from path dependence ${ }^{24}$ to regulatory failure, ${ }^{25}$ might be argued to explain the pattern of inefficient transition described above. At least some explanation, however, may lie in the welfare consequences of securities markets' network character.

Securities markets can be usefully understood and analyzed through the prism of network effects. ${ }^{26}$ Such effects arise where the utility of a

20. References to trading systems and securities market systems are meant to reference the array of available trading mechanisms in modern securities markets-mechanisms ranging from auctionbased exchanges to dealer-based screen systems (e.g., NASDAQ), electronic matching systems, and other ATSs.

21. See Yakov Amihud \& Haim Mendelson, A New Approach to the Regulation of Trading Across Securities Markets, 71 N.Y.U. L. REV. 141 1, 1434 (1996).

22. See S. REP. No. 94-75, at 1-2 (1975); Marshall E. Blume \& Michael A. Goldstein, Quotes, Order Flow, and Price Discovery, 52 J. Fin. 22 1, 222 (1997).

23. See Special Study Group of the Committee on Federal Regulation of Securities, ABA, Business Law Section, Special Study on Market Structure, Listing Standards and Corporate Governance, 57 BUS. LAW. 1487, 1492 (2002).

24. Path dependence can be distinguished in temporal terms from the network-based lock-in analysis addressed in Part II.B of this Article. Path dependence can be understood as lock-in arising from historical practice, while network lock-in is driven by expectations regarding the future behavior of consumers and competitors.

25. See Macey \& Haddock, supra note 4 , at 316.

26. See generally Ahdieh, supra note 6. While such effects are commonly termed "network externalities," this characterization fails to acknowledge the reasonable possibility that network economies may be internalized effectively in any given case. See id. at 288 n.37. 
particular good or service increases with additional consumers. ${ }^{27}$ The resulting demand-side economies of scale have been widely acknowledged in telephones, computer operating systems, and an array of other technologies. ${ }^{28}$ Extending this range of application, I proposed a network theory of securities markets. ${ }^{29}$

Each additional trader or issuer to join a public securities market enhances both market liquidity and price discovery, thereby increasing the value of the securities market generally, the value of the given securities trading system the trader or issuer joins (ranging from the NYSE to Island $\mathrm{ECN}$ ), and the value of the range of individual securities trading on that market. ${ }^{30}$ However, this pattern has the potential to delay and even prevent market transition, including the creation of new securities markets, the emergence of new market technologies, and the linkage of existing markets. ${ }^{31}$

Inversely to more familiar negative externalities, if the social benefits of network entry exceed the benefits to any single entrant, new markets or technologies will be underutilized. ${ }^{32}$ By way of example, the weakness of

27. See Mark A. Lemley \& David McGowan, Legal Implications of Network Economic Effects, 86 CAL. L. REV. 479, 481 (1998) (describing network markets as those "in which the value that consumers place on a good increases as others use the good"); Howard A. Shelanski \& J. Gregory Sidak, Antitrust Divestiture in Network Industries, 68 U. CHI. L. REV, 1, 5 (2001) ("A network externality, or 'network effect,' exists when the value of a product or service increases with the breadth of demand for that product or service.").

28. See Lemley \& McGowan, supra note 27, at 535 (computer operating systems); Shelanski \& Sidak, supra note 27, at 5, 59 (telephone systems and computer operating systems). See also Michael Klausner, Corporations, Corporate Law, and Networks of Contracts, 81 VA. L. REV. 757, 759, 761 (1995) (asserting the presence of network effects in the selection of corporate contract terms).

29. See generally Ahdieh, supra note 6. Kal Raustiala has proposed a distinct network effects analysis of securities regulation directed to the rise and implications of administrative agency coordination across national borders. See Kal Raustiala, The Architecture of International Cooperation: Transgovernmental Networks and the Future of International Law, 43 VA. J. INT'L L. I, 8-9 (2002). The implications of the present analysis are not limited to the securities markets, which is evident in the parallels to be found in the development of electricity networks in the United States and western Europe, and particularly in the choice between alternative current (AC) and direct current (DC). See generally Thomas Parke Hughes, Networks of Power: Electrification IN WEStERN SOCIETY, I880-1930 (1983).

30. See Ahdieh, supra note 6, at 286-89. See also Nicholas Economides, Network Economics with Application to Finance, 2 FIN. MARKETS, INSTITUTIONS \& INSTRUMENTS, Dec. I993, at 89.

31. For a more in-depth explanation of these phenomena, see Ahdieh, supra note 6, at 297-321. For further discussion of network effects and their existence in securities markets, see id. at 280-81, 283-96.

32. See Lemley \& McGowan, supra note 27, at 515-16 (discussing the risk of suboptimal network size arising from the inability of existing users to compensate prospective users for the incremental value they add to the network). For a general challenge to claims of potential inefficiencies in the presence of network economies, see Daniel F. Spulber \& Christopher S. Yoo, Access to Networks: Economic and Constitutional Connections, 88 CORNELL L. REV. 885, 921-33 (2003). 
securities markets in central and eastern Europe, as well as the puzzling persistence of bank financing in Germany and Japan, might be traced back to such underutilization. In each of these cases, potential market sponsors and market professionals will not be fully compensated for the social utility that their extension or participation in the network will produce. ${ }^{33}$ Market entry will therefore be suboptimal. As a further consequence of such underutilization, there are increased prospects that the "wrong" (i.e., pareto inefficient) market structure may emerge. ${ }^{34}$ Additionally, technological development may be delayed and otherwise efficient technologies placed out of a given market's reach on account of size-related underinvestment. ${ }^{35}$ Limited technological innovation in U.S. securities markets and particularly on the NYSE may thus be rooted in size-related network

33. For purposes of the argument herein, I do not, with limited exceptions, distinguish among the various subjects of network effects in securities market transition, including market sponsors, on the one hand, and market professionals and issuers on the other. Market sponsors, however, are at least somewhat distinct, as they are not only subject to the network dynamic in securities markets (i.e., subjects of the network-driven competition to identify what will prove to be the dominant infrastructure of a given market), but are the applied mechanism of that dynamic. In the simplest terms, they are the network.

Consequently, present and potential market sponsors, from exchanges to ECNs, have a more direct hand in the network competition described above than brokers, dealers, and even issuers. By dint of their investments in network infrastructure, within the limits of the network economic forces at work, market sponsors seek to position themselves to remain or become the prevailing network standard for securities trading. Cf. Ahdieh, supra note 6 , at $333 \mathrm{n} .265$. The NYSE thus seeks to remain the dominant network trading system, while NASDAQ seeks to displace it. Market professionals and issuers, by contrast, simply seek to identify whether NASDAQ will ultimately emerge as the dominant network, or will fall short.

Notwithstanding this important distinction in both position and perspective, however, market sponsors are ultimately faced with the same network pressures as market professionals and issuers. See id. at 312 n.152. Because of the tipping and size effects described above, they may be loathe to invest efficiently in market creation and development; they may engage in inefficient competitive practices to secure the supernormal returns of network dominance; and they may become difficult to displace, even notwithstanding potential technological inefficiencies, once they have secured a dominant network position.

A further point also deserves note: The vast majority of market sponsors are likely not competing to serve as the dominant network trading system. $C f$. id. Rather, they are better conceived as subnetworks within the dominant network. In this view, the relevant network is not any given trading system (e.g., the NYSE, NASDAQ, or the Pacific Stock Exchange), but the communications system that links these trading systems. Of course, the latter may be developed and provided by an existing trading system, such as NASDAQ. Most trading systems, however, are merely participants in this network and not present or potential sponsors of it. Consequently, the somewhat simplifying treatment of market sponsors as subjects of the network dynamic in securities market transition, along with market professionals and issuers, is appropriate.

34. See Ahdieh, supra note 6 , at 302 .

35. See id. at 303-04; Mendelson \& Peake, supra note 3, at 447. 
effects. New trading and communications technologies may simply lack sufficient critical mass to take hold. ${ }^{36}$

Besides such "size effects," 37 network externalities may also produce a winner-take-all competitive dynamic. ${ }^{38}$ Since bigger is better in the presence of network effects, securities markets and other network markets can be expected to tip to a dominant, if not singular, trading network, as new participants jump on the prevailing network's bandwagon. ${ }^{39}$ In the face of this prospect, however, several potential inefficiencies-" "tipping effects"-may arise. ${ }^{40}$ To begin with, potential market sponsors, ${ }^{41}$ issuers, and even market professionals ${ }^{42}$ (e.g., brokers and dealers) may exhibit a rational hesitation to enter the market. ${ }^{43}$

36. While property rights may help to resolve negative externalities, network externalities in securities markets are less likely to be ameliorated through mechanisms of ownership. See Ahdieh, supra note 6, at 333-34.

37. In these general manifestations, network effects can be understood as a form of positive externality. See Ahdieh, supra note 6, at 297. See also Niva Elkin-Koren \& Eli M. Salzberger, Law and Economics in Cyberspace, 19 INT'L REV. L. \& ECON. 553, 563 (1999); B. Peter Pashigian \& Eric D. Gould, Internalizing Externalities: The Pricing of Space in Shopping Malls, 41 J.L. \& ECON. 115, 140 (I998) (analyzing positive externalities arising from anchor stores in malls).

38. See Shelanski \& Sidak, supra note 27, at 5. See also Ahdieh, supra note 6, at 305 n.1 I4 (characterizing network markets as "tippy," such that "the coexistence of incompatible products may be unstable, with a single winning standard dominating the market") (quoting Stanley L. Besen \& Joseph Farrell, Choosing How to Compete: Strategies and Tactics in Standardization, J. ECON. PERSP., Spring 1994, at 117-18); Michael L. Katz \& Carl Shapiro, Systems Competition and Network Effects, J. ECON. PERSP., Spring 1994, at 93, 105-06; Lemley \& McGowan, supra note 27, at 496-97.

39. See Katz \& Shapiro, supra note 38, at 105-06 (explaining "tipping" as the tendency of one system to pull away from its rivals in popularity once it has gained an initial edge).

40. See Ahdieh, supra note 6, at 305 \& n.1 I4 (describing tipping effects that may arise in the presence of strong network effects). Cf. Malcolm Gladwell, THE TipPing PoINT: How LitTle THINGS CAN MAKE A BIG DIFFERENCE 7 (2000) (referring to "tipping" in broader terms, as a form of contagious behavior manifest with social phenomena, including crime and education).

41. "Market sponsors" include the NYSE, Island ECN and similar ATSs, NASDAQ, the regional exchanges, and others presently or potentially in the same position.

42. "Market professionals" include brokers, dealers, and the like.

43. See Lemley \& McGowan, supra note 27, at 515-16; Stephen Craig Pirrong, The SelfRegulation of Commodity Exchanges: The Case of Market Manipulation, 38 J.L. \& ECON. 141, 155 n.24 (I995) (describing network barriers to entry by traders); Shelanski \& Sidak, supra note 27, at 10. Cf. David M. Schizer, Benign Restraint: The SEC's Regulation of Execution Systems, 101 YALE L.J. 1551, 1559-60 (1992). In essence, tipping engenders an expectations failure by which market entry and development are hindered. In Russia, for example, prior to the intervention of government authorities, brokers and exchanges were discouraged from incurring the substantial costs involved in the development of a national trading system. See TIMOTHY FRYE, BROKERS AND BUREAUCRATS: BUILDING MARKET INSTITUTIONS IN RUSSIA 48 (2000). Through the government's tipping of the market, however, a single trading system attracted the investment and interest of Russia's investors and professionals. See id. at 132 (reasoning that "[a]bout one-half of all trades are formally conducted through the RTS, but ... price and counterparty information obtained through the RTS [are] responsible for almost all trades"); Ahdieh, supra note 6, at 313. 
In essence, if one market will ultimately dominate, identification of the "right" market becomes crucial, ${ }^{44}$ especially given the substantial sunk costs of participation. ${ }^{45}$ Deferred entry may therefore be a rational strategy for every individual market participant, ${ }^{46}$ and especially for potential market sponsors or developers of new technologies. ${ }^{47}$ In emerging markets, for example, sponsorship of new trading systems can be expected to lag, given the substantial risk that any particular system will not emerge as the dominant trading network and may ultimately find itself without any market share to speak of. This may explain why a truly national trading system did not emerge in Russia until Russian market regulators gave their imprimatur to the particular efforts to create the now-dominant Russian Trading System ("RTS"). ${ }^{48}$

Assuming entry can be induced, other inefficient tipping effects may arise. First, the prospect of emerging as a network monopolist may induce inefficient competitive behavior, including penetration pricing and similar predatory practices. ${ }^{49}$ Second, given tipping effects, the result of network competition may not be efficient. Considering the importance of size in network industries, strong first-mover advantages may produce undesirable outcomes. ${ }^{50}$ By way of example, sharp competition in the early days of the Russian securities markets may capture the first possibility, ${ }^{51}$ while the dominance of the NYSE suggests the second. ${ }^{52}$ Finally, as the case of the

44. See Ahdieh, supra note 6, at 308-09.

45. This ohstacle is dramatically enhanced by the inability of failed network competitors to recover their sunk costs. See William J. Baumol, Janusz A. Ordover \& Robert D. Willig, Parity Pricing and Its Critics: A Necessary Condition for Efficiency in the Provision of Bottleneck Services to Competitors, 14 YALE J. ON REG. 145, 160 (1997).

46. See Amitai Aviram, Regulation by Networks, 2003 BYU L. REV. (forthcoming 2003 ).

47. Developers of new technologies face the greatest risk from the potential inability to recover sunk costs in network markets. See Baumol et al., supra note 45. The greater scope of resulting network barriers to entry by market sponsors than market participants (e.g., brokers and issuers) is thus the most important distinction among the universe of securities market participants subject to the network effects described herein. See suprá note 33.

48. See infra Part VI.B.

49. See Michael L. Katz \& Carl Shapiro, Product Introduction with Network Externalities, J. Indus. ECON., Mar. 1992, at 55, 73. Lemley and McGowan highlight the potential for inefficient competitive strategies, where firms seek to

establish their own products as standards on which competition in the market, or in after markets for complementary goods, will be based.... Because the returns to the standards winner will be higher than in "normal" markets, relatively risky strategies, such as predation or, at a minimum, penetration pricing, might be rational in a networks market.

Lemley \& McGowan, supra note 27, at 495 (internal footnotes omitted).

50. See Katz \& Shapiro, supra note 38, at 94; Lemley \& McGowan, supra note 27, at 495-97.

51. See Ahdieh, supra note 6, at 315.

52. See Jonathan R. Macey \& Hideki Kanda, The Stock Exchange as a Firm: The Emergence of Close Substitutes for the New York and Tokyo Stock Exchanges, 75 CoRnEll L. REV. 1007, 1024 (1990); Seligman, supra note 4, at 640. 
NYSE also suggests, first-mover advantages in network securities markets can be expected to persist due to strong lock-in effects. In a network environment, simply put, market participants may be unwilling to switch, even to an otherwise more efficient (but necessarily smaller) trading network. ${ }^{53}$

Collectively, size and tipping effect patterns can be seen in the challenge of developing a system of intermarket trading communication. To maximize network gains, universal participation in a single securities market network (i.e., interlinked markets) is preferred. ${ }^{54}$ However, given the network-related possibilities of market underutilization, barriers to entry, excess entry, and lock-in, this may not come to pass. No potential market sponsor may be willing to undertake the substantial costs of constructing an effective market linkage or providing efficient levels of investment in an existing system. Alternatively, there may be multiple network linkages, at least for a time, with the attendant inefficiencies that result. Market professionals and issuers, perhaps most importantly, may delay their election of a preferred trading system for trading or listing, given that tipping effects may lead to their choice's abrupt displacement. Finally, the linkage system that ultimately emerges from such competition may not be the pareto-efficient one, given first-mover advantages. On account of network market lock-in, however, it may persist. ${ }^{55}$ Brokers and dealers, as well as issuers, may flock to an early entrant and thereafter prove unwilling to transition to an alternative, otherwise preferred, network, given the necessary loss of network size efficiencies associated with any such shift. ${ }^{56}$

Network effects in securities markets may therefore constitute a serious obstacle to the efficient emergence of new markets in countries from Germany and Japan to central and eastern Europe. They may also interfere with the development of new market technologies for

53. See Di Noia, supra note 7 , at 43 (finding that "network externalities may lock-in exchanges into inefficient outcomes, due to a lack of coordination, even in perfect competition"); Sean P. Gates, Standards, Innovation, and Antitrust: Integrating Innovation Concerns into the Analysis of Collaborative Standard Setting, 47 EMORY L.J. 583, 609-10 (1998); Klausner, supra note 28, at 791.

54. See Ahdieh, supra note 6, at 305 n.117.

55. While the enumerated examples of potential transition failures all fall in the category of what is commonly termed "market microstructure," it bears reiterating that network effects may impact other aspects of securities market transition as well. It is for this reason that I commonly refer to issues of "market structure," rather than simply "market microstructure." See supra note 13.

56. As this example makes clear, while certain of the potential network inefficiencies described herein are particularly relevant to the welfare-maximizing behavior of market sponsors, the collective network dynamic that may stymie efficient securities market transition is a result of the network-driven choices of both market sponsors, and market professionals and issuers. See supra note 33. 
communication, trading, and clearing and settlement in established markets such as the United States. If recent cases of transition failure are elucidated by a network theory of market transition, however, how can such network obstacles be overcome? Having identified the problem of market transition in microeconomics, we might fruitfully look to the strategic models of game theory for a solution.

\section{A GAME THEORY OF MARKET TRANSITION}

Overcoming the network obstacles to efficient market transition begins with identification of the strategic nature of the relevant network interactions. In this analysis, reliance on the familiar Prisoner's Dilemma game construct is ill-advised. Instead, after outlining the expectationsbased character of the relevant network obstacles in the following section, I identify the less familiar, but no less pervasive, coordination game strategic dynamic as a better framework for the analysis of securities market transition. As I will conclude, however, traditional solutions to coordination games-communication, convention, and focal points-may not suffice to ensure the creation of new markets or the evolution of existing ones.

\section{A. COORDINATING EXPECTATIONS IN TRANSITION}

As commonly understood, law serves to remedy problems of collective action $^{57}$ by mandating cooperation in cases where individual incentives may counsel otherwise. ${ }^{58}$ Among other situations, this dynamic arises in public goods problems and in the presence of negative externalities. Mandating support of basic police functions, providing for the common defense, and rationing the use of parks and other public resources, for example, fall into the former category, while regulating environmental harms and restricting public nuisances fall into the latter. In these cases, law constrains individually rational strategies in the service of socially, and ultimately even individually, optimal outcomes. ${ }^{59}$

From this perspective, it is not surprising that legal scholars have often looked to the Prisoner's Dilemma to understand law's social and economic

57. See Steven Hetcher, Creating Safe Social Norms in a Dangerous World, 73 S. CAL. L. REV. I, 31 (1999).

58. See Richard H. McAdams, A Focal Point Theory of Expressive Law, 86 VA. L. REv. 1649. 1650 (2000).

59. See, e.g., Andrew T. Guzman, A Compliance-Based Theory of International Law, 90 CAL. L. REv. 1823, 1844 (2002) (suggesting that the presence of law alters payoffs and thus solves the Prisoner's Dilemma by imposing a penalty for the breach of a promise to comply). 
functions. ${ }^{60}$ In the Prisoner's Dilemma game, players have "defection in their heart" and must be restrained from their tendency toward betrayal. ${ }^{61}$ This, of course, is exactly the worry that drives the regulation of public goods and negative externalities. It is not, however, the strategic dynamic of securities market transition.

The creation of new markets, the modernization of available technologies on existing markets, and the creation of intermarket linkages do not involve familiar problems of collective action ${ }^{62}$ in which law must intervene to mandate cooperation. ${ }^{63}$ As such, they fall outside much of what legal scholars, particularly in law and economics, see as law's function. ${ }^{64}$ Instead, law's role in securities market transition is primarily one of encouragement, information-provision, and facilitation.

To overcome network barriers to efficient market transition, there is no need to alter the incentives of the issuers, market sponsors and professionals, and secondary service providers involved in that process. For the most part, those incentives naturally favor elimination of relevant network barriers. Rather, the key to efficient transition lies in shaping parties' expectations. ${ }^{65}$

Given the importance of network size to the value of public securities markets, ${ }^{66}$ market participants must develop expectations of the future choices of both present and future market participants. ${ }^{67}$ While I may or may not care whether others buy the same car or use the same soap as I do,

60. The use of game theory in legal scholarship, in fact, is almost exclusively directed to the Prisoner's Dilemma. See, e.g., Thomas W. Merrill, Pluralism; the Prisoner's Dilemma, and the Behavior of the Independent Judiciary, 88 Nw. U. L. REV. 396 (1993); John Shepard Wiley, Jr., Reciprocal Altruism as a Felony: Antitrust and the Prisoner's Dilemma, 86 MiCH. L. REV. 1906 (1988).

61. See Hetcher, supra note 57 , at $42-43$.

62. See id. at 31 .

63. See McAdams, supra note 58, at 1650. Cf. RuBEn LeE, WHAT Is AN Exchange? THE Automation, MANAGEMENT, AND REgulation OF FinANCIAL MARKETS 264-65, 308-09 (1998).

64. See McAdams, supra note 58 , at 1650.

65. See Ahdieh, supra note 6, at 308-09. See also Aviram, supra note 46, at 13; Katz \& Shapiro, supra note 38, at 94-95; Larry E. Ribstein \& Bruce H. Kobayashi, Choice of Form and Network Externalities, 43 WM. \& MARY L. REV. 79, 112 (2001) ("In general, entrepreneurs can help shape users' expectations by convincing potential users that a new form is likely to become a standard. These expectations, in turn, determine whether users will adopt or shun a new form.") (internal footnote omitted).

66. See supra Part II.B.

67. See Christopher S. Yoo, Vertical Integration and Media Regulation in the New Economy, 19 YALE J. ON REG. 171, 280 (2002). 
I very much care whether they trade or list their equity shares on the same market since the value of that market to me depends on their decisions. ${ }^{68}$

To allocate resources, select standards, and otherwise participate in the network-driven securities market, market participants need to know what trading standards market sponsors (e.g., exchanges and ECNs) and market professionals (e.g., brokers and dealers) are likely to adopt. ${ }^{69}$ They need to know what institutions they plan to develop and introduce. Finally, they must intuit what they are prepared to invest in standardization or upgraded technology. ${ }^{70}$ Absent such information, market participants will be unable to develop accurate expectations of other market participants' likely strategies.

The network inefficiencies in securities market transition, however, are grounded in such expectations failures. This is evident in the potential tipping effects described above. Tipping effect barriers to entry arise from potential entrants' ignorance of which standard will ultimately prevail in the winner-take-all competition that can be expected in the presence of strong network effects. Potential issuers in Russia long resisted listing on any particular exchange or trading system, for example, due to their lack of confidence in whether securities markets would take hold in Russia and lack of knowledge of what form those markets would take (e.g., floorbased or screen-based), if they did. ${ }^{71}$

Network lock-in, meanwhile, arises from existing network members' unwillingness to risk any move to a new network absent some sense of existing and future consumers' likelihood of electing to join that network as welI. $^{72}$ Again, the development of Russian securities markets is suggestive. Inefficient floor-based trading persisted until public regulators flagged the screen-based model of the RTS as the preferred standard. ${ }^{73}$

68. See Ahdieh, supra note 6, at 288-89. Likewise, the choice of currency is network-driven since the relative utility of U.S. dollars versus Russian rubles as a medium of exchange is directly proportional to the size of each currency's network of users. See Ross M. Starr \& Maxwell B. Stinchcombe, Exchange in a Network of Trading Posts, in MARKETS, INFORMATION, AND UNCERTAINTY: ESSAYS IN ECONOMIC THEORY IN HONOR OF KENNETH J. ARROW 216, 218 (Graciela Chichilnisky ed., 1999) [hereinafter MARKETS, INFORMATION, AND UNCERTAINTY].

69. As the identification of both market sponsors and market professionals suggests, the need for clear expectations extends both vertically, to competitors, and horizontally, to other market actors. The utility of a broker's membership in a particular ECN, for example, is impacted not only by the choices of other brokers, but also by the choices of other ECNs, issuers, and the like. See Ahdieh, supra note 6, at 309 . See also supra note 33 .

70. See Ahdieh, supra note 6, at 304.

71. See infra Part VI.B.

72. See Ahdieh, supra note 6 , at $317,318 \&$ n. 176 .

73. See infra Part VI.B. 
As described in the economics literature, networks exhibit multiple fulfilled expectations equilibria. ${ }^{74}$ Alternative market linkages are available. Multiple trading technologies might be selected. Banks, in the extreme case, might be chosen over securities markets as the dominant source of corporate finance. ${ }^{75}$ In the face of such alternatives, efficient outcomes are not precluded, but neither are they given. ${ }^{76}$ The outcome may be a less efficient market, a slower connection, or a less robust technology. ${ }^{77}$

Efficient securities market transition, therefore, requires coordination. Specifically, market participants amid transition must coordinate their expectations of one another. ${ }^{78}$ By way of example, coordinating expectations of whether a particular securities market communications system or some alternative choice is to be preferred is essential to overcome the network barriers to transition described above. 'Through such coordination, market participants may optimize entry, identify which systems warrant expanded investment, and select mechanisms of interconnection that provide maximum network efficiency. ${ }^{79}$

74. See Nicholas Economides, How to Enhance Market Liquidity, in GLOBAL EQUITY MARKETS: TECHNological, Competitive, AND Regulatory Challenges 90, 92-93 (Robert A. Schwartz ed., 1995).

75. This choice constitutes a slightly different network dynamic, as suggested below, see infra Part VI.D, but it can be included for exemplary reasons.

76. See Ahdieh, supra note 6, at 328 .

77. In more formal terms, the market may or may not arrive at a Nash equilibrium outcome in which market participants join the same network or adopt compatible technologies. See id. Nash equilibria-recently popularized in A BEAUTIFUL MIND (Universal Studios 2001)-are those equilibria from which no player would rationally choose to defect absent some alteration in other players' strategies. See Eric A. Posner, Economic Analysis of Contract Law After Three Decades: Success or Failure?, 112 YALE L.J. 829, 876 (2003). See also McAdams, supra note 58, at 1656-57. Even if the market does achieve some Nash equilibrium, it will not necessarily be the pareto-, or even the KaldorHicks-, efficient one.

Pareto efficiency is achieved by a shift that enhances some individuals' utility without diminishing the utility of any other individual. See Don Herzog, Externalities and Other Parasites, 67 U. CHI. L. REV. 895, 917 (2000). Kaldor-Hicks efficiency, on the other hand, emphasizes social utility, arising whenever the aggregate utility increases, even if the utility to some individuals is consequently decreased. See Eric A. Posner, Controlling Agencies with Cost-Benefit Analysis: A Positive Political Theory Perspective, 68 U. CHI. L. REv. 1137, 1146-47 (2001).

78. See Dennis W. Carlton \& J. Mark Klamer, The Need for Coordination Among Firms, with Special Reference to Network Industries, 50 U. CHI. L. REV. 446, 465 (1983). See also Ahdieh, supra note 6, at 328-31; Klausner, supra note 28 , at 803-04. In constructing a network theory of corporate contracts, Michael Klausner has also emphasized the centrality of expectations and their coordination in overcoming potential network inefficiencies. See Klausner, supra note 28 , at $802,828,840$.

79. The same is true of any particular securities market (i.e., in the case of market creation) and of any particular market technology or other standard. 
Such coordination must occur both vertically and horizontally. Thus, any given securities market participant-whether a present or potential market sponsor, market professional, issuer, or some other entity-must develop reliable expectations as to both his or her competitors and those otherwise situated within the securities market scheme. ${ }^{80}$ For an efficient transition to a new intermarket communication system, for example, an institution considering sponsorship. of the linkage must determine whether competitors may develop alternative systems; whether brokers or dealers who rely on existing mechanisms of communication will switch to the new, initially smaller communication network; and whether existing and future exchanges, and even electronic trading sites, will agree to link to the new system. From the perspective of a market professional, meanwhile, it is essential to develop expectations of whether alternative securities market structures are likely to be developed, whether such structures will take an auction or dealer format, and whether competing (as well as later entering) brokers and dealers will elect the existing or the alternative network. ${ }^{81}$ Absent such expectations, the array of network-driven size and tipping effects described above may stymie any prospect of efficient securities market transition.

\section{B. THE COORDINATION GAME OF MARKET TRANSITION}

Given the pattern of strategic interaction described above, it is readily apparent that a Prisoner's Dilemma analysis will not suffice to describe the mechanisms of securities market transition. Although game theory analysis

80. See supra note 69.

81. Of course, one might think of every market and transition as requiring such coordination. In the ordinary case, the market can achieve an effective degree of coordination without law or public intervention. Given the large sunk costs that characterize securities markets and network industries generally, however, ordinary market mechanisms of entry and exit cannot be relied on to facilitate an efficient equilibrium. See Joseph Farrell, Cheap Talk, Coordination, and Entry, 18 RAND J. ECON. 34, 34-35 (1987) (describing this pattern in the monopoly context). This obstacle is aggravated by the inability of market participants to recover their sunk costs in the presence of strong network effects. See Baumol et al., supra note 45, at 160. See also Ahdieh, supra note 6, at 306-07. As a consequence, the market's ordinary tool of coordination-short-term failures of cost-is unlikely to be an effective source of coordination in securities market transition. See Farrell, supra, at 34-35. By a similar token, competition among relevant networks, here varied market trading systems, cannot be relied on to consistently produce efficient outcomes.

More generally, coordination of understandings about the nature of property, contracts, or money, for example, undoubtedly stands in the background of all economic activity. Money is the consummate network good and the consummate potential coordination problem. Yet, in most cases, questions of coordination stand in the background. The dominant strategic interactions are thus captured by a Prisoner's Dilemma game or other game construct. In securities market transition and other transitions in the presence of strong network effects, however, coordination is the central feature of the relevant strategic interactions. 
in the law has looked almost exclusively to the Prisoner's Dilemma, ${ }^{82}$ other strategic models exist to capture the altered dynamics of securities market creation and restructuring. ${ }^{83}$ Better insight into law's potential role in market transition can thus be found in little-used coordination games, ${ }^{84}$ in which aligned interests and a resulting preference for coordination-the hallmarks of network environments, such as securities markets-are the dominant features. ${ }^{85}$

Coordination games involve just the strategic challenge found in securities market transition: the adjustment of player expectations. ${ }^{86}$ This is apparent in the most basic model of coordination, the Meeting Place coordination game, which I outline here as a choice of pareto-ranked securities market systems. ${ }^{87}$

82. See supra note 60. See also Hetcher, supra note 57, at 31. Cf. Duncan Snidal, Coordination Versus Prisoners' Dilemma: Implications for International Cooperation and Regimes, 79 AM. POL. SCI. REV. 923, 923-24 (1985) (noting the exclusive emphasis on Prisoner's Dilemma games in political science generally and in the study of international cooperation in particular).

83. See Snidal, supra note 82, at 941 (finding that coordination games, rather than Prisoner's Dilemma analysis, may better characterize issues of international cooperation). Cf. Amir N. Licht, Games Commissions Play: $2 X 2$ Games of International Securities Regulation, 24 YALE J. INT'L L. 61, 65 (1999). Licht argues that

in analyzing international securities regulation, the Prisoners' Dilemma is a useful paradigm in only a few of the problems that arise in practice. In many others, other $2 \times 2$ game models better depict the conflictual situation that countries face and help to assess the prospects of international cooperation in these situations.

Id. See also id. at 94. To similar effect, Eric Posner has pointed out the importance of distinguishing coordination games and Prisoner's Dilemmas, given consequent differences in the likelihood that efficient norms will emerge to solve the relevant problem and in the likelihood that those norms will be optimal. See Eric A. Posner, Law, Economics, and Inefficient Norms, 144 U. PA. L. REV. 1697, 1715 (1996).

84. Coordination games have not received much attention among legal scholars. See Hetcher, supra note 57 , at $7,42 \mathrm{n} .160$. While various explanations for such neglect might be suggested, one possibility is the erroneous assumption that where interests are aligned, as in coordination games, efficient outcomes will occur without legal intervention. See id. at $47 \&$ n. 47 (citing examples). A related notion suggests that true coordination game social dynamics are rare, as distinct from Prisoner'sDilemma-type social interactions. To the contrary. "[e]veryday life is full of situations where we have to coordinate our actions with those of other people." See Karl Warneryd, Conventions and Transaction Costs, in 1 THE NEW PALgRaVe DictionaRy of ECONOMICS AND THE LAW 460 (Peter Newman ed., 1998) [hereinafter DICTIONARY OF ECONOMICS]. Coordination games, in fact, capture many of the most fundamental elements of human interaction. Experimental evidence also supports the conclusion that coordination failures are more than a "theoretical curiosity." See RUSSELL W. COOPER, COORDINATION GAMES: COMPLEMENTARITIES AND MACROECONOMICS 1 (1999).

85. See supra note 11 .

86. See McAdams, supra note 58 , at 1679,1680 (describing the capacity of a judge to achieve an outcome merely by altering the parties' expectations).

87. In Schelling's original game, a husband and wife were asked where and when they would meet each other if they were separated at a department store. See id. at 1656 (explaining Schelling's original game). For more examples of coordination games, see. also id. at 1654-58. Schelling also conducted other "matching game" experiments. See Robert Sugden, A Theory of Focal Points, 105 
FIGURE 1. Meeting Place coordination game

Market participant 2

Market participant 1

\begin{tabular}{|c|c|c|}
\hline & \multicolumn{2}{|c|}{ Market participant 2} \\
\hline & System A & System B \\
\hline System A & $10,10^{88}$ & 0,0 \\
\hline System B & 0,0 & 5,5 \\
\hline
\end{tabular}

In this game, the essential task of the players is fairly understood as a need to coordinate expectations. ${ }^{89}$ This need arises from the central feature of coordination games: the existence of multiple Nash equilibria ${ }^{90}$ from

ECON. J. 533, 543 (1995) (noting "Schelling's New York game, Choose a Disc, Choose a Letter, and Coloured Disks").

The game of securities market transition, of course, is more complex than the simple game I outline herein. While I develop a more complete characterization of that game elsewhere, see Robert B. Ahdieh, Playing Games: Chicken, Battle of the Sexes, and the Model of Securities Market Transition (unpublished manuscript) (on file with author), for present purposes, application of a generic coordination game approach to securities market transition will suffice.

88. By way of convention, I characterize payoffs as follows: row player, column player. In this game, market participant l's payoff is first and market participant 2's is second. Separately, it bears noting that I use cardinal rather than ordinal payoffs because the former distinguishes the strength of preferences. Cf. Licht, supra note 83, at 82 (employing ordinal numbering to denote payoff structures). Beyond this rough character, the enumerated quantities are random, both within and among the games outlined herein.

89. See McAdams, supra note 58 , at 1657 ("Solving cooperation problems requires a change in payoffs. Solving coordination problems, however, just requires the right kind of expectations."); Robert E. Scott, The Limits of Behavioral Theories of Law and Social Norms, 86 VA. L. REv. 1603, 1622 n.40 (2000) ("In the case of coordination games, the law ideally will help solve the problem by changing parties' expectations (rather than their incentives) ...."). See also Robert Sugden, Spontaneous Order, in 3 DICTIONARY OF ECONOMICS, supra note 84, at 485, 488-89. Edna Ullmann-Margalit distinguishes between "theoretical" and "deontic" expectations in this regard-the former being in the nature of "ground frost is expected to develop during the night" and the latter exemplified by "I shall expect you here tomorrow." Ullmann-Margalit suggests that the expectations at work in coordination games move from theoretical to deontic as we shift from single-shot games (as in the present case, see infra note 113 ) to iterated (or recurrent, in Ullmann-Margalit's terms) ones. See EDNA UlLmanN-Margalit, THE EMERGENCE OF NORMS $88-89$ (1977).

90. See Sugden, supra note 89 , at 488 (identifying multiple equilibria as a core characteristic of coordination problems). See also COOPER, supra note 84, at ix; Snidal, supra note 82, at 932 ("Stated more formally, the problem in the coordination game is one of choice between multiple stable and efficient equilibria over which states have opposed interests, whereas in PD [Prisoner's Dilemma] the problem is getting away from a single stable but inefficient equilibrium."). In addition to the two readily apparent pure strategies, there is a third mixed-strategy equilibrium, where players elect each strategy with a given probability. See DOUglas G. BAIRD, ROBERT H. GERTNER \& Randal C. PICKER, GAME THEORY AND THE LAW 37 (1994); Farrell, supra note 81, at 36. Given the existence of 
which no player will diverge absent an alteration in his or her counterpart's strategy. ${ }^{91}$

At these Nash equilibria, here in the northwest and southeast quadrants, players' expectations and interests are aligned. ${ }^{92}$ Such alignment directly tracks the congruent interests and, ideally, expectations of securities market participants in the three patterns of transition highlighted herein: the creation of new capital markets, the adoption of new trading technologies, and the expansion of markets through increasingly effective intermarket communication systems. In the latter case, for example, market participants desire to converge on a universal linkage system in order to maximize the network gains from trade. ${ }^{93}$ They want, in game theoretic terms, to "meet" and thereby achieve the positive payoffs of the northwest or southeast quadrant. Furthermore, given the pareto ranking of the alternative market linkage systems, they particularly prefer to participate jointly in System A.

Yet they will not necessarily join in the same linkage system, let alone the pareto-efficient System A, absent some coordination of expectations. ${ }^{94}$ Both may select System B, which we might reasonably characterize as a

such multiple strategies, some have suggested the inevitable need for empiricism in the analysis of coordination games. See Richard Zeckhauser, Distinguished Fellow: Reflections on Thomas Schelling, J. ECON. PERSP., Spring 1989, at 153, 158. See also SCHELLING, supra note 11, at 163-64.

91. See McAdams, supra note 58, at 1656-57 (observing that coordination games produce Nash equilibria in which no player gains by unilaterally altering his or her strategy). As a consequence, coordination games are stable and have been termed "self-enforcing." See THOMAS C. SCHELLING, MiCROMOTIVES AND MACROBEhAVIOR 119 (1978); ARTHUR A. STEIN, Why NaTIONS COOPERATE: CIRCUMSTANCE AND CHOICE IN INTERNATIONAL RELATIONS 42 (1990); Licht, supra note 83, at 103; Gerald J. Postema, Conventions at the Foundation of Law, in I DICTIONARY OF ECONOMICS, supra note 84 , at 465,468 . Such Nash equilibria should not be confused with a pareto-efficient equilibrium. While Nash equilibria may be pareto efficient, they need not be. See Licht, supra note 83, at 90 . See also Partha Dasgupta, On Some Problems Arising from Professor Rawls' Conception of Distributive Justice, 4 THEORY \& DECISION 325, 341 (1974).

92. See Scott, supra note 89 , at 1622 n. 40 . Players' interests need not be completely aligned in coordination games, however; they only need to be partially aligned.

93. See supra Part II.B.

94. Both individual and collective payoffs thus depend on each player's capacity to develop effective expectations of what her counterpart will do. More precisely, such payoffs depend on developing accurate expectations of what one's counterpart in a coordination game will expect her to predict she will do, and so on. See Postema, supra note 9l, at 469-70. Reasoning in coordination games

is distinctive, however, in that it is reasoning from a common point of view .... Unlike the emulative reasoning attributed to parties in classical game theory, this form of social intelligence does not involve replicating the reasoning of the other party. Rather, it involves simulation or approximation of reasoning together-reasoning aimed at finding reasons we share.

Id. See also McAdams, supra note 58, at 1659; Zeckhauser, supra note 90, at 155. This complex exercise holds the ultimate key to the efficient resolution of coordination games. 
floor-based rather than screen-based trading system. Once they arrive at this Nash equilibrium, moreover, substantial risk of inefficient lock-in arises, given the unwillingness of either player to switch to the paretoefficient System A, absent some expectation that his or her counterpart will also switch. ${ }^{95}$ Even worse, absent accurate expectations of the other player's strategy, one player may elect to join a screen-based system (e.g., System A), while the other joins the available floor-based system (e.g., System B). In the network-driven securities markets, this produces the lowest possible payoffs and greatest degree of inefficiency. ${ }^{96}$

95. Some may find this possibility easier to envision by characterizing market participant 1 as a single actor, while market participant 2 represents the collection of all other market participants in a given market. A temporal distinction may also be helpful.

96. The coordination game character of securities market transition can also be described from the perspective of potential market sponsors. See supra note 33. For most trading systems, which cannot expect to serve as the mechanism of interconnection among competing trading systems, the strategic dynamic described above, vis-à-vis market participants generally, is fully applicable.

As to the more limited universe of true market sponsors (i.e., those market participants situated to serve as a communications network of existing network trading systems), the coordination game pattern remains, but in slightly altered form. There, given the greater competitive dynamic at work, the simplified, nonconflictual game in the text and even the slightly more conflictual Battle of the Sexes game described later, see infra note 102, do not suffice. Instead, the dynamic of the so-called Chicken game may be more appropriate. It attempts to model the familiar game in which two cars race toward one another, and the loser is the first to swerve to avoid a collision. See McAdams, supra note 58 , at 1794 .

FIGURE A. Chicken game

Driver B

\begin{tabular}{|c|c|c|c|}
\hline & & Maintain speed & Turn off \\
\hline \multirow{2}{*}{ Driver A } & Maintain speed & $-10,-10$ & $5,-2$ \\
\hline & Turn off & $-2,5$ & 0,0 \\
\hline
\end{tabular}

In this circumstance, the relevant Nash equilibria arise from the players' choice of contrasting strategies in the southwest and northeast quadrants. In Chicken, all parties would most prefer that their opponent turn off, while they maintain speed. On the other hand, turning off is overwhelmingly favored over pressing onward in the face of the other player's insistence on doing the same.

When competing market sponsors seek to establish themselves as the dominant network, the Chicken game would appear to be an appropriate framework for analysis. See Ahdieh, supra note 87. In that case, all potential market sponsors seek, by dint of precommitment, investment, and other mechanisms, to establish themselves as unwilling to "turn off" from their defined course. If they can do so, their competitor's rational strategy will be to defer to them in order to avoid the conflictual northwest strategy, in which both suffer a substantial loss. See id. Even in the case of one true market 
Market strategies in securities market transition, as in coordination games generally, can consequently be described as interdependent. ${ }^{97}$ This distinguishes such games from the Prisoner's Dilemma, in which each player will choose to defect regardless of what the other does. ${ }^{98}$ By contrast, in the coordination game of securities market transition, network effects cause market participants to very much care what others do. Given the choice, they will do the same. ${ }^{99}$

sponsorship, then, a coordination game dynamic remains in place, even if a more conflictual one. The ensuing analysis therefore remains applicable even to market sponsorship in networked securities markets.

97. See Postema, supra note 91, at 468 ("Their choices are interdependent when each realizes that his best choice depends on anticipating the choices of the others who at the same time are trying to anticipate his."). See also COOPER, supra note 84, at ix. In Prisoner's Dilemma games, each player's dominant strategy is consistent across the behavior of his or her counterpart (i.e., it is independent of his or her strategy). By contrast, coordination game players do not have a dominant strategy. See STEIN, supra note 91, at 30; Licht, supra note 83, at 103.

The interdependence of strategies and the further consequences that follow from it are what distinguish coordination games from a Harmony game, to which coordination games may sometimes sound similar. In a Harmony game, each party has a dominant strategy of the pareto-optimal solution, making coordination, expectations, and the other concerns outlined herein irrelevant. See Licht, supra note 83 , at 109 .

98. See Posner, supra note 83, at 1714 ("In a prisoner's dilemma, each player does better by cheating if the other cooperates, and each player does better by cheating if the other player cheats. Thus, whether or not one player knows the strategy of the other player, each has an incentive to cheat."). See also Hetcher, supra note 57, at 42-43 ("In contrast to the iterated [Prisoner's Dilemma] problems discussed in the previous Section, players in coordination games do not have defection in their hearts."); Scott, supra note 89, at 1622 n.40. See generally Barry Nalebuff, Prisoners' Dilemma, in 3 DiCTIONARY OF ECONOMiCs, supra note 84, at 89. In the Prisoner's Dilemma, we have the problem of a single inefficient equilibrium, while coordination games exhibit multiple potentially pareto-ranked equilibria and an inability to effectively choose among them.

99. I am not the first to note the relevance of coordination games to network industries and environments. Most such work has drawn the connection only in passing or indirectly. See, e.g., Clayton P. Gillette, Lock-In Effects in Law and Norms, 78 B.U. L. REV. 813, 833-34 (1998) (linking norms, coordination, and network effects). See generally Farrell, supra note 81. Even where the relationship has been more central to the relevant analysis, authors have not treated the relationship comprehensively. Klausner highlights a coordination element in the selection of corporate contract terms, focusing particularly on the potential of state corporate-law default terms to serve as Schelling focal points. See Klausner, supra note 28 , at $800-01,828$. He does not, however, evaluate the situation from a game theoretic perspective or develop such a model. Others also have noted a connection. See, e.g., Raustiala, supra note 29, at 68; Eric Talley, Disclosure Norms, 149 U. PA. L. REV. 1955, 2019-20 (2001) (linking norms, coordination, and network effects in the context of expressive law); Karl Warneryd, Network Externality and Convention, in 2 DiCTIONARY OF ECONOMICS, supra note 84, at $675,675-76$. Such linkage in the legal literature has often come in the context of technology and technological development. See, e.g., Elkin-Koren \& Salzberger, supra note 37, at 574; Steven A. Hetcher, Norm Proselytizers Create a Privacy Entitlement in Cyberspace, 16 BERKELEY TECH. L.J. 877,902 n.88 (2001) (noting the connection between the coordination norm concept and network effects literature). It also has been a recurring theme in analyses of the evolution of norms, where network effects have been cited as a potential obstacle to the process. See Niva Elkin-Koren, Copyrights in Cyberspace-Rights Without Laws?, 73 CHI.-KENT L. REv. 1155, 1184 (1998); Gillette, supra, at 834; Posner, supra note 83, at 1717, 1718 \& n.56. Douglas G. Baird, Robert H. Gertner, and 


\section{PATHS AND PITFAlls of EFFECTIVE COORDINATION}

If securities market transition is a coordination game, then how is that game best solved? Stating the question differently, how are the coordination barriers to efficient transition-to efficient market creation, modernization, and interlinkage - best overcome? There would seem to be some innate, if unarticulated, assumption that coordination games should solve themselves. As the case of securities market transition suggests, however, they may not always do so. There are often too many participants who are too diverse and too dispersed to allow spontaneous resolution. The existence of some degree of conflict, such as a preexisting preference for auction versus dealer markets, may also prevent ready resolution. Students of coordination games have thus studied three potential mechanisms for the resolution of coordination games: communication, convention, and focal points. Yet they all have limitations that may limit their effectiveness in securities market transition.

Most obviously, coordination games may be solved where players can communicate. If the relevant parties could talk, one might surmise, they could readily articulate and thereby coordinate their respective expectations. Yet there are several critical difficulties with this scenario. First, problems of "cheap talk"-communication that does not bind the speaker and is therefore of diminished value to the listener ${ }^{100}$-will degrade the value of communication, at least whenever any dimension of conflict exists in the relevant game. ${ }^{101}$ Such conflict creates an incentive to overstate one's commitment to one's preferred solution, even if not to defect from whatever equilibrium is ultimately reached. By overstating my commitment, I may modify the expectations of a counterparty, causing that

Randal C. Picker do the most complete game theoretic analysis of network effects from a coordination game perspective, analyzing, in game theory terms, the specific game issues of excess momentum and excess inertia in network industries. See BAIRD ET AL., supra note 90, at 202-13. They do not delve into the consequent regulatory role in the creation of such networks, which is odd given their legal theme. Furthermore, they engage in a sequential game analysis, which is not consistent with the singleshot, or, at least, evolutionary pattern of securities market transition. See infra note 113. Finally, Sugden briefly describes matching games to include the issues analyzed herein: "using compatible equipment in a network of communications [and] trading at the same location ...." See Sugden, supra note 87 , at 543 .

100. See Warneryd, supra note 99 , at 676 ("[I]t seems most sensible to model verbal utterances as practically costless. Adding the possibility of such actions to a game then only nominally affects the set of equilibria... . Talk is cheap and only actions that directly affect payoffs matter."). See also McAdams, supra note 58 , at 1658 n.20.

101. Such conflict is likely to exist in securities market transition, where sunk costs in particular institutional structures and arrangements will cause market sponsors, market professionals, issuers, and others to favor coordination generally, but to prefer coordination around some particular standard (e.g., auction versus dealer system or periodic versus continuous trading). 
counterparty to elect a strategy of deference to my preference, versus insistence on his or her own preference.

More specifically, in securities market transition-a Battle-of-theSexes-type game ${ }^{102}$ - potential market sponsors, as well as the array of other market participants, can be expected to insist on their commitment to their preferred trading model and standards. The NYSE will insist that it could never abandon its auction model, while NASDAQ will assert its unvarying commitment to its dealer model. One market participant will insist on its unwillingness to switch from network $A$ to network $B$, while its counterpart will assert its inability to switch from $B$ to $A$. All this may be said notwithstanding the reality of substantial flexibility on the part of the

102. As an alternative to the Chicken game described above, see supra note 96 , the game of securities market transition might alternatively be modeled around the anachronistically named Battle of the Sexes. See generally Stephen D. Krasner, Global Communications and National Power: Life on the Pareto Frontier, 43 WORLD POL. 336, 339 n.4 (1991); Snidal, supra note 82, at 931-32. Battle of the Sexes is often cited as the relevant game in the analogous context of technological, and other forms of, standard setting. See BAIRD ET AL., supra note 90 , at $41-42$ (describing standard setting as a Battle of the Sexes game); Licht, supra note 83, at 102 (applying the Battle of the Sexes game to international cooperation among states). In this conflictual coordination game, wife and husband wish to spend the evening together (hence, the need for coordination), but have distinct preferences regarding where to go-a boxing match or the ballet (hence, the element of conflict). See BAIRD ET AL., supra note 90, at 41-42; Licht, supra note 83, at 102 n. 137. See also Krasner, supra, at 339-40.

FIGURE B. Battle of the Sexes game

Husband

\begin{tabular}{|c|c|c|}
\cline { 2 - 3 } \multicolumn{1}{c|}{} & Ballet & Boxing \\
\hline Wife & 10,5 & 3,3 \\
\hline Boallet & $-3,-3$ & 5,10 \\
\hline
\end{tabular}

In this game, both husband and wife will rationally insist that they intend to go to their preferred meeting place, regardless of where the other goes. In this way, each may be most likely to achieve his or her preferred coordination solution. This can also be characterized as a Solomon problem. More formally, it is an issue of "preference revelation," in which a bargaining dimension creates an interest in disguising incentives (and intentions). See Daniel A. Farber, Parody LostPragmatism Regained: The Ironic History of the Coase Theorem, 83 VA. L. REV. 397, 407 (1997).

An even better model of the strategic patterns in securities market transition than the Battle of the Sexes, however, is the familiar Chicken game. See supra note 96 . While less commonly applied to standard-setting exercises than the Battle of the Sexes, I argue elsewhere that Chicken, in which inverted player strategies produce the relevant Nash equilibria, is most readily modified to capture the game of securities market transition. See Ahdieh, supra note 87. 
relevant market participants. Given the potential for such distortion in securities market transition, it should come as no surprise that communication may actually lessen, rather than enhance, the prospect of achieving a coordinated outcome. ${ }^{103}$

Other limitations on the use of communication as a remedy to coordination failures can also be noted. The size and heterogeneity of the relevant population may undermine the remedial efficacy of communication. ${ }^{104}$ In network-driven securities markets, the relevant population-from market sponsors to other trading systems, from brokers to dealers, and from issuers to secondary service providers-is both massive and incredibly diverse. Communication is therefore unlikely to be an efficacious remedy for coordination problems that may arise. ${ }^{105}$ Network-related obstacles to efficient market transition also may interfere with the willingness of market actors to participate in any communicationbased effort at coordination. Until assured of adequate participation in such efforts at negotiation (i.e., of sufficient network size), market actors, whether in the securities markets or elsewhere, may hold back.

A final barrier to communication as a mechanism for coordinating expectations in securities market transition is evident in the strictures of section 1 of the Sherman Act and similar statutes abroad. The type of communication, and resulting coordination, that securities market transition necessitates constitutes just the sort of horizontal cooperation and agreement among competitors that the Act bars. ${ }^{106}$

103. See McAdams, supra note 58, at 1674.

104. Other questions of inclusion would also arise from any attempt at direct communication in securities market transition. A large part of the network efficiencies of greater compatibility and market linkage in securities market transition arises from future participants. As such, substantial externalities can arise from any attempt to resolve securities market transition through communication. See Sugden, supra note 89 , at 492 (describing the limits of spontaneous order as a solution to coordination problems where externalities are present).

105. Because of the limitations of communication, whether actual or in the form of indirect signals, the simultaneity of plays is irrelevant to the game of securities market transition. Among a large population, no single player's move is likely to overcome existing resistance to entry, even if it could be effectively communicated to all players. In network environments, moreover, it is not only the universe of existing players whose strategies matter, but future entrants as well. By definition, then, players cannot know the strategies of all relevant participants in the game of securities market transition, or other network transitions.

106. See Richard J. Haray, Balancing Antitrust and Labor Policies on the Court: Wood v. National Basketball Association, 61 ST. JOHN's L. REv. 326, 326 (1987) (“Antitrust law, principally embodied in the Sherman Act, encouraged the development of a competitive market by prohibiting the concerted actions of horizontal competitors seeking monopolistic control.") (internal footnotes omitted). See also 15 U.S.C. $\$ 1$ (2000) (prohibiting collusion agreements "in restraint of trade or commerce"). 
Given the limitations of communication, "conventions" have been identified as an alternative remedy to coordination problems. ${ }^{107} \mathrm{~A}$ commercial norm favoring active public securities markets over more conservative bank financing arrangements or one favoring order-based trading in a particular country, for example, might serve to coordinate expectations in an efficient fashion. ${ }^{108}$

Again, conventions may not be an adequate solution where the relevant collection of players is sufficiently numerous or heterogeneous. ${ }^{109}$ Large or diverse groups are more likely to rely on law to coordinate because they lack the common culture and experience necessary for norms to emerge and be effective. ${ }^{110}$ There is also reason to believe that conventions are relatively unstable, ${ }^{111}$ and hence, less attractive sources of

107. Louis Kaplow and Steven Shavell have defined convention as "a set of background understandings that determine... meaning...." Louis Kaplow \& Steven Shavell, Fairness Versus Welfare, 114 HARV. L. REv. 961,1109 (2001). See also McAdams, supra note 58, at $1690 \mathrm{n} .95$ (explaining the difference between norms and conventions).

108. Elaborating on the place of conventions in securities market transition, such a role can be ohserved in the transition to new market technologies. One might imagine some convention tied to the selection of the technology of order-driven versus quote-driven markets. In fact, the sharp prevalence of order-driven markets in Europe is likely just such a convention. See Norman S. Poser, The Stock Exchanges of the United States and Europe: Automation, Globalization, and Consolidation, 22 U. PA. J. INT'L ECON. L. 497, 500-01 (2001). In this case, the common European standard might help to coordinate the expectations of central and eastern European markets to favor an order-driven approach in their creation of new markets. Even existing markets that utilize quote-driven systems can be expected to adjust their expectations to a convention favoring order-driven markets' network dominance. Conventions might also find ready application in the case of market interlinkage. It is relatively less likely to facilitate the efficient creation of new markets, however, given the seemingly definitional absence of any standing convention in such cases.

109. Cf. Hetcher, supra note 57 , at 39 . Such size and diversity fairly can be said to characterize public securities markets, which involve a wide array of heterogeneous players.

110. See Robert C. Ellickson, ORder Without LAW: How NEIGHBORS SETTLE DisPutes 250 (1991); UlLmanN-MARGalit, supra note 89, at 92; Sugden, supra note 87, at 546 ("In games like these, the common culture and common experiences of the players seem to play central roles."). Ellickson focuses on how close-knit a relevant group is, suggesting a rough correlation of such social intimacy with the size of the group. See ElLICKSON, supra, at 182. See also Hetcher, supra note 57, at 35. On the question of size in particular, see R.H. Coase, The Problem of Social Cost, 3 J.L. \& ECON. $1,17-18$ (1960). A notable exception to this generalization is the lex mercatoria, a body of custom that extended among a substantial number of traders in an array of different cultures and locations. See Jane Kaufman Winn, Couriers Without Luggage: Negotiable Instruments and Digital Signatures, 49 S.C. L. REV. 739, 745 (1998). See also Susan Thomas Johnson, Internet Domain Name and Trademark Disputes: Shifting Paradigms in Intellectual Property, 43 ARIZ. L. REV. 465, 483 (2001). The lex mercatoria, however, would seem to be the exception that proves the general rule that large or diverse groups are less effective at coordination.

111. See Amy L. Wax, Expressive Law and Oppressive Norms: A Comment on Richard McAdams's "A Focal Point Theory of Expressive Law," 86 VA. L. REV. 1731, 1767-68 (2000) (noting the ability of "underdogs" to alter equilibrium strategy); Paul G. Mahoney \& Chris Sanchirico, Competing Norms and Social Evolution: Is the Fittest Norm Efficient? 45 (Working Paper, 2001) 
the coordination necessary for securities market transition. This may be particularly true amid transition. Thus, Edna Ullmann-Margalit suggests that coordination norms that arise in response to novel coordination problems are more likely to be dictated by some external authority (i.e., law), rather than arise spontaneously (i.e., convention). ${ }^{112}$

For this reason, a relevant existing convention may be an effective remedy for network barriers in securities market transition; but where a convention does not already exist, creating it may be no easier than achieving coordination generally. ${ }^{113}$ Conventions may be useful mechanisms of social and economic control in securities markets and

("Efficient norms can be surprisingly fragile in response to random shocks."), available at http://papers.ssrn.com/paper.taf?abstract_id=229694.

112. See UlLMANN-MARGALIT, supra note 89 , at 83.

113. The creation of new conventions is thus difficult, especially in securities market (and similar) transitions. See Hetcher, supra note 57, at $30 \mathrm{n} .121$ ("Unfortunately, however, the story as to how norms emerge is still not well understood."). See also Cristina Bicchieri, Norms of Cooperation, 100 ETHICS 838, 844 (1990). Cf. Posner, supra note 83, at 1711 ("We need a mechanism to explain why the new efficient norm would arise."). In game theory, the emergence of conventions has focused on repeated games in which a pattern of learning can be predicted. See Randal C. Picker, Simple Games in a Complex World: A Generative Approach to the Adoption of Norms, $64 \mathrm{U}$. CHI. L REV. 1225, 1255 (1997) (developing a model in which repeat plays lead to an efficient resolution of coordination games). Specifically, analyses have focused on the existence of asymmetries among players, which can recurrently be observed and used to develop regularized strategies based on the distinct character of the players. Over time, these come to constitute conventions. See Michael I. Krauss, Regulation vs. Markets in the Development of Standards, 3 S. CAL. INTERDISC. L.J. 78 I, $788-94$ (1994); Postema, supra note 91 , at 469 . See also ROBERT SUGDEN, THE ECONOMICS OF RIGHTS, CO-OPERATION AND WELFARE 42-43 (1986).

Our game of securities market transition, however, is better understood as a single-shot game, not a repeated game. See SUGDEN, supra, at 47 (noting the single-shot nature of Schelling's games and analysis). See also SCHELLING, supra note II, at 67-68. This is readily apparent in the creation of new markets and in the adoption of particular trading technologies or linkages. While market participants have recurring interactions over these and other issues of market transition, they do not interact over the same game. Rather, a market is established, a technology adopted, or a linkage constructed. Where the same game is repeated, it is not likely to be played by the same players. Recurrence can not, therefore, be relied on to produce effective conventions in securities market transition. See SUGDEN, supra, at 47.

There are, of course, iterative elements to securities market transition. The adoption of any given technology is commonly a phased process. Likewise, given some degree of market continuity, major market players, including exchanges, trading systems, brokerage houses, and issuers, are likely to participate successively in the development of multiple features of a common market. This pattern adds some reputational dimension to the game of securities market transition, as well as potentially resolution-facilitating asymmetry. While these may help to enhance coordination, they nonetheless do not give rise to a repeat game dynamic. The introduction of distinct market technologies, and even different elements of a single technology, raise varied incentives and hence strategies for each market participant, weakening the essential iterative element of repeat games. This notion is explored further in Ahdieh, supra note 87, in which 1 elaborate on the nature of the game of securities market transition. Among other possibilities, securities market transition might be modeled as a sequential, extended-form game played out over a limited multiple of periods. 
elsewhere, but are likely to be less effective tools for the adjustment of social and economic behavior, as in efficient transition. ${ }^{114}$

Finally, analyzing single-shot games played without communication, a category encompassing securities market transition, ${ }^{115}$ Thomas Schelling has proposed a third potential mechanism for the resolution of coordination games: so-called focal points. Focal points are those equilibrium choices in coordination games "that, for cultural or psychological reasons, [are] more 'salient' and therefore seem[] more natural ...."16 A focal point analysis thus asks whether a particular solution stands out, or is prominent, ${ }^{117}$ and suggests that such solutions are most likely to be chosen by any given player and, therefore, to be the preferred choice of all players. If conventions resolve coordination games because parties have the same expectations, and communication solves them because it allows the parties to share their expectations, focal points solve coordination games by signaling to the players what their counterpart will likely expect.

Conceptually, Schelling captured such salience with the suggestion that paratroopers, separated from one another upon landing, will meet at the place featured most prominently on their identical map, even if there are better alternatives, as long as the importance of meeting is sufficiently great and the prominence of the spot on their map makes it the most likely successful meeting point. ${ }^{118}$ Schelling's Meeting Place game, incorporating players' choice of both time and place in the entire city of New York, produced substantial coordination, with paired players regularly

114. Other difficulties with conventions as the solution to coordination problems also can be noted. First, they may be more susceptible to lock-in than other sources of regulation. Clayton Gillette makes this argument in questioning the efficiency of norms. See Gillette, supra note 99, at 813-16. Of course, this contrasts with the potential instability of conventions noted above. Additionally, conventions may not effectively absorb the externalities that arise from transition, see Sugden, supra note 89, at 492 (questioning the efficiency of spontaneous order where externalities exist), and thus may be inadequate tools in transitional situations.

115. See supra note 113.

116. David A. Strauss, Common Law Constitutional Interpretation, 63 U. CHI. L. REv. 877, 910 (1996). On focal points generally, see McAdams, supra note 58, at 1659-63.

117. See BAIRD ET AL., supra note 90, at 39; SUgDEN, supra note 113, at 49; UlLMANNMARGALrT, supra note 89 , at 83-84; McAdams, supra note 58, at 1659 . The term "salience" is commonly used in the coordination game literature as an alternative characterization of focal points. See Postema, supra note 91, at 469-70 (describing the regularity of behavior as a source of salience because it makes "one particular combination of actions stand out as uniquely eligible among a number of possible combinations"). See also SUGDEN, supra note 113, at 89-90 (noting the interchangeable terminology of prominence, salience, and focal points).

118. See Mark J. Roe, Bankruptcy and Debt: A New Model for Corporate Reorganization, 83 Colum. L. Rev. 527, 541 (1983). 
favoring Grand Central Station as their meeting place and noon as their meeting time.

In securities markets, focal points might help to facilitate the transition process. Expectations regarding the choice of an auction versus dealer market structure, for example, might be coordinated by way of the focal point of neighboring states' recent choice of an auction model. ${ }^{19}$ As with conventions, however, this solution is circular: If a focal point already exists, then players can effectively coordinate their expectations around it; if not, we remain in the same boat. If focal points are to solve the game of market transition, some extrinsic source must render a given point focal.

In securities market transition and in at least certain other network transitions, the foregoing coordination game analysis suggests that law may have an important role to play. But what is the form of that law? Surely, given the sharply distinct strategic dynamic at work, the traditional conception of law as coercive sanction is ill-suited to securities market transition. Rather, law's role must necessarily fall within the range of function and form bounded by communication, convention, and focal points. At their intersection, we may expect to find law's appropriate design.

\section{TOWARD A CUEING THEORY OF LAW IN MARKET TRANSITION}

Law's role in encouraging the alignment of expectations necessary to solve coordination games, including the game of securities market transition, is best found in the interplay of the alternative solutions described above. Regulatory agencies may thus facilitate effective private communication, cohesion, and action through their creation of a modified form of focal points. This cueing theory of law posits, in essence, that a

119. Focal points have found diverse application in law. See William N. Eskridge, Jr. \& Philip P. Frickey, Foreword: Law as Equilibrium, 108 HARV. L. REV. 26, 57 (1994) (articulating a view of statutory "plain meaning" as providing a focal point); Jack L. Goldsmith \& Eric A. Posner, A Theory of Customary International Law, 66 U. CHI. L. REV. 1113,1171 (1999) (characterizing treaties as serving a focal function in the creation of customary international law); Strauss, supra note 116, at 910-11 (describing constitutions as playing a focal role); Mark Tushnet \& Larry Yackle, Symbolic Statutes and Real Laws: The Pathologies of the Antiterrorism and Effective Death Penalty Act and the Prison Litigation Reform Act, 47 DUKE L.J. 1, 81 n.388 (1997) (describing expressive statutes as focal points). See also Licht, supra note 83, at 104 (describing international organizations as a source of focal points); Posner, supra note 83, at 1719 (characterizing a property recording system as a medium by which focal points can be created). 


\section{form of law that I term "regulatory cues" may be an essential feature of efficient securities market transition. ${ }^{120}$}

Specifically, such cues may serve to create focal points, which in turn can facilitate the coordination of players' expectations, and hence, the resolution of a coordination game. ${ }^{121}$ Law and regulation may serve this cueing function in several ways: providing information, an important element in achieving coordination in information-oriented securities markets; shrinking the universe of possible outcomes (i.e., discouraging noncoordination and inefficient coordination equilibria); and facilitating communication, particularly by enhancing the efficiency of such

120. A variety of cueing theories have been suggested both in law and other fields. Most prominently in the legal literature, Philip Bobbitt has argued that Supreme Court decisions may sometimes serve a cueing function, rather than serve as a legitimizing force, a check on federal power, or the source of doctrinal shifts in the Court's jurisprudence. See Philip BobBtT, Constitutional FATE: THEORY OF THE CONSTITUTION 190-95 (1982). In this scenario, the Court may hear a case to communicate some message to a coordinate branch of government. See id. at 191-95 (relying on National League of Cities v. Usery, 426 U.S. 833 (1976), as an example of the Court's cueing function). See also Gregory P. Magarian, Toward Political Safeguards of Self-Determination, 46 VILL. L. REV. 1219,1249 n. 158 (2001) (discussing the cueing theory of review, under which "the Court needs to fire the occasional shot across Congress' bow to remind it to maintain political safeguards").

Focusing specifically on the Supreme Court's grants and denials of certiorari, scholars have devcloped arguments based on cueing theory. See Saul Brenner, Granting Certiorari by the United States Supreme Court: An Overview of the Social Science Studies, 92 LAW LIBR. J. 193, 195 (2000) (positing an "error correction strategy" by which "a justice who wants to reverse the decision of the lower court will vote to grant certiorari, while a justice who is happy with the lower court decision will vote to deny certiorari"); id. at 196 (addressing an "outcome prediction strategy" and empirical analyses that show that "certiorari voting could be based on the justices' evaluation of their probability of winning at the final vote").

A nonlegal cueing theory, advanced by Dhavan Shah, asserts that public opinion can be analyzed in terms of "frames and cues" that accompany issues in news media reporting. See Dhavan V. Shah, Mark D. Watts, David Domke \& David P. Fan, News Framing and Cueing of Issue Regimes: Explaining Clinton's Public Approval in Spite of Scandal, 66 PUB. OPINION Q. 339 (2002). Because the majority of citizens form conclusions about many political and social issues in response to information gathered through news media, the organizational frames of those news stories, as well as embedded cues within them, including descriptive labels that become normative terms in future stories, become internalized by the public and thus influence the public's ultimate opinions. See id. at 341-42.

121. To similar effect, Sugden refers to the potential role of international law as a source of focal points for the division of resources under the North Sea. See SUGDEN, supra note 113, at 87-88. See also Jonathan R. Hay \& Andrei Shleifer, Private Enforcement of Public Laws: A Theory of Legal Reform, 88 AEA PAP. \& PROC. 398, 400 (1998).

This builds on Richard McAdams's exploration of the role of law in solving coordination problems (though not network problems particularly). As in the present analysis, McAdams posits such a role as grounded in law's creation of focal points. That analysis speaks of focal points as commonly conceived, however, rather than in the broader sense I propose. Most significantly, it is directed to particular outcomes-it is about how law can achieve a particular policy goal without reliance on public sanctions. See infra Part IV.B.2. As a partial consequence, it also relies in large part on the existence of some second- or third-party sanction, which the proposed cueing does not. See infra Part IV.B.I. 
communication. ${ }^{122}$ To better appreciate the significance and nature of such legal cues, 1 consider the twin functions and potential forms of regulatory cues in the following section, and thereafter, the character and nature of cues in market transition.

\section{A. LAW'S CUEING FunCTION IN SECURITIES MARKET TRANSITION}

One can begin to elaborate on the role of regulatory cues in market transition by identifying cueing's essential functions in that process. These arise in two phases tied to the twin concerns that arise in multiple Nash equihbria coordination games, including securities market transition. ${ }^{123}$

To begin with, regulatory cues can help signal coordinated outcomes generally as focal and thereby reduce the prospect of noncoordination. At this stage, public regulators act to identify those cases in which coordination-in the form of common standards or otherwise-is preferred, should be pursued, or will not be interfered with by public authorities. ${ }^{124}$ Rather than seek to render a particular Nash equilibrium salient, such regulatory cues make Nash equilibria generally stand out by contrasting them with noncoordination outcomes.

Recalling the coordination game schema mapped out above, ${ }^{125}$ this element of cueing's role seeks to achieve the greater efficiencies of the northwest and southeast quadrants, versus the southwest and northeast quadrants. At these coordination points-or Nash equilibria-the players have successfully coordinated their strategies to meet on the same system, with attendant efficiency gains. At the outset, then, regulatory cues may help to ensure some degree of coordination and to avoid the alternative noncoordination outcomes. In the case of securities market transition, regulatory cues at this preliminary phase might be characterized as encouraging the widespread participation of market actors in some

122. As I will describe in greater detail in Part IV.A, Klausner has previously posited a coordinating function-specifically, a focal point role-for law in corporate governance. See Klausner, supra note 28 , at 764,800-01. It also bears noting that the cueing, or signaling, function for law that I describe herein is conceptually distinct from the signaling function widely relied on in the law and economics literature to describe behavior intended to communicate information regarding the character or nature of a particular individual, institution, or product. See ERIC A. POSNER, LAW AND SOCIAL NORMS 18-19 (2000).

123. See supra Part III.B.

124. This cueing function also can be thought of as reducing the costs of transition, thereby facilitating a change from the Prisoner's Dilemma game, which exists without entry, to a coordination or assurance game. See Gillette, supra note 99, at 819-20.

125. See supra Part III.B. 
universal trading or communications system, whether it is System A (e.g., a screen-based system) or System B (e.g., a floor-based system).

Beyond this initial role, and closer to focal points as commonly understood, regulatory cues may also help to signal a preference for a particular category of coordination outcomes, or even for a specific one. ${ }^{126}$ In this way, regulatory agencies can use cues to facilitate at least a KaldorHicks efficient outcome, if not always the pareto-efficient one. In our model, such second-stage cues would aim to encourage market participants' selection of System A particularly. In pursuit of this goal, a market regulator might engage in an array of cueing behaviors, including the provision of information, subsidies, and other resources that point market participants to the pareto-efficient coordination equilibrium of System A. ${ }^{127}$

In serving to signal as focal coordination outcomes generally and efficient coordination outcomes particularly, regulatory cues can be understood to serve two purposes. First, they narrow the universe of potential solutions. Second, they enhance common knowledge through the provision of information. Regulatory cues thus enhance the potential for coordinated expectations and outcomes by decreasing the range of potential strategies for an increasingly aligned array of players.

This is the essential need in coordination games, whether it be securities market transition or otherwise. Where the basic dynamic is coordinative in nature, regulatory restraints or other adjustments to players' incentives are unnecessary. This remains true even if some element of conflict persists among the players. ${ }^{128}$ In securities market transition, for example, even if various market actors diverge in their preference for one trading or communications system over another, regulatory cues' adjustment of expectations should nonetheless help to achieve a stable equilibrium. As long as the several market sponsors or professionals ultimately prefer to operate on the same system or standard, as they will in

126. Cf. Picker, supra note 113 , at 1286. It bears noting that law does not serve these cueing functions only where interests are matched; rather, focal points and cueing functions are especially important where there is an element of conflict in the relevant game. See McAdams, supra note 58, at 1672-73 (describing Schelling's demonstration of this result). See also Sugden, supra note 87, at 548.

127. See supra text accompanying notes 86-96. Others have suggested various narrower focal point functions for law. Among the most common is the notion of law as serving a publicity function. See Scott, supra note 89, at 1629 (discussing McAdams's focal point model). Another notion of law as a focal point emphasizes its facilitation of "second-party sanctions." See McAdams, supra note 58, at 1685. My notion is broader and does not depend on such private sanctioning behavior.

128. See supra notes 99,101 and accompanying text. 
the presence of sufficiently strong network effects, ${ }^{129}$ their incentives essentially continue to be aligned. While strategic behavior will necessarily increase in the presence of conflict, regulatory cues can continue to serve an important coordinative role. ${ }^{130}$ This is true even at the point of greatest conflict in securities market transition, where market sponsors are competing to serve as the dominant trading intercommunication system, or network of networks. ${ }^{131}$ ln such cases, regulatory cues may still serve to adjust player expectations and thereby decrease the prospect of costly noncoordination, while increasing the prospect of efficient coordination.

If regulatory cues are a means of coordination, what actual forms might they take? Potential cues in securities market transition can be readily identified within the paired categories outlined above: first, law's signaling of coordination outcomes generally as focal, and second, its highlighting of certain preferred outcomes in particular. ${ }^{132}$

One might identify several potential cueing mechanisms with regard to regulatory cues' initial task of reducing the potential for noncoordination by identifying cases in which coordination is important and thereby prioritizing that goal for market participants. To begin with, regulatory agencies-particularly those charged with responsibility for competition policy-may pursue this goal by signaling an intention to withhold antitrust enforcement directed at particular efforts at coordination. ${ }^{133}$ In this way, as

129. See supra Part II.B.

130. Richard McAdams elaborates this point in his analysis of the role of focal points in conflictual coordination games. See McAdams, supra note 58, at 1653, 1672-78. See also infra notes I67-69 and accompanying text. The ultimate claim, however, is not that cueing will invariably suffice to achieve optimal outcomes without further regulation. Rather, cueing increases the prospect of such optimality by moving market participants closer to optimal outcomes.

131. See supra note 33.

132. The degree of conflict in a given coordination game, as in the distinction of network interaction among various securities market brokers and between directly competing market sponsors, may at least indirectly impact the relative importance of the two functions of regulatory cues. Thus, in the case of competition between potential market sponsors, the first-order prioritization of coordination in any given case may be especially important. On the other hand, market sponsors may more readily avoid the entry barriers to some coordination outcome, given their relatively greater resources and consequent ability to direct substantial sunk cost investment to a particular network structure, thereby precommitting themselves to that trading form and ultimately inducing coordination at that equilibrium. To be clear, however, this can resolve only the initial coordination game risk of a failure to coordinate. It does nothing to address the second-order concern with lock-in at some inefficient coordination point. Depending on the balance of such factors, the form of regulatory cueing in any given case of securities market transition can be expected to vary.

133. Even the tangential connection between the public authorities and resulting coordination efforts among market participants can be expected to reduce the likely incidence of collusive behavior. 
exhibited in the implied antitrust immunity of the securities markets, ${ }^{134}$ law may help to encourage more active participation in bargaining efforts directed to coordination outcomes. ${ }^{135}$ Market participants that might otherwise shy away from negotiated efforts to set common standards or otherwise facilitate market linkage may find encouragement in such a public signal.

Market regulators may also discourage noncoordination outcomes in securities market transition in more proactive ways. Securities regulators may do so through the cue of threatened government standards for the securities markets. Proposed rules by the Securities and Exchange Commission ("SEC") mandating particular order-handling procedures to achieve best execution, or rules requiring adoption of particular computer systems to enhance intermarket trading compatibility, may thus serve a cueing function, regardless of their ultimate adoption or rejection. By positing a particular coordination solution and the rationale for it, public authorities might signal a willingness to accept the risk of dictating a suboptimal coordinated solution in order to achieve desired coordination benefits. In the face of this prospect, the relative priority of achieving coordination can be expected to rise among relevant market participants, including brokers in the first example, and exchanges and other trading systems in the second.

The case of the Intermarket Trading System ("ITS") in the U.S. securities markets may suggest this pattern. In this transition to enhanced intermarket linkage, a number of trading systems and market professionals joined forces to develop their own independent communications system, the ITS, in the face of an SEC proposal to mandate creation of a distinct and apparently less desirable one. ${ }^{136}$ As this example suggests, certain regulatory proposals may be mildly coercive, yet also serve a cuing function. In such cases, relevant regulators may dictate, or at least strongly encourage, coordination, but not specify any particular means to such an end.

Having securities regulators posit potential solutions may also help to render coordination focal by providing players with information favoring

134. See Ahdieh, supra note 6, at 342-43. In the United States, such immunity arose out of the combined regulation of the SEC and the Supreme Court.

135. As this makes clear, regulatory cues may at times be solving, or facilitating efforts to solve, the relevant game. Furthermore, they may achieve the latter simply by enhancing the players' common knowledge, but also by facilitating more effective or efficient bargaining among interested players.

136. This example is described in greater detail below. See infra Part V.B. 
coordinated outcomes generally. ${ }^{137}$ In securities markets, such information would include information regarding markets in which coordination has successfully produced efficiency gains, evidence of the limited perparticipant cost of achieving coordination through market linkage, and information regarding trading compatibility standards. Such information can help various market participants-whether market sponsors or professionals, investors, or issuers-more accurately gauge the benefits of coordination. The provision of such information by a third party also may be important, given the resulting elimination of any cheap talk devaluation of it. ${ }^{138}$

In addition to the potential threat of government standards and the provision of information, law's initial cueing role in securities market transition may aIso be served by bringing market participants together. In the Russian securities markets, for example, one might note the Federal Commission on Securities Markets' convocation of a conference of established broker-dealers, who thereafter formed the National Association of Stock Market Participants (known as "NAUFOR"), Russia's preeminent self-regulatory organization ("SRO"), and its dominant trading system, the RTS. ${ }^{139}$ After several years of halting market development, during which a multitude of exchanges and variously linked brokers competed for limited market share, and market growth stagnated, Russian regulators' "intervention" to encourage coordinated development of a screen-based system shifted the pace of market development into higher gear. This transition was achieved, however, with little if any regulatory mandate.

Such "locking in a room" is also manifest in the HDTV standardsetting process, where the Federal Communications Commission's Advisory Committee on Advanced Television Service heIped to jump-start stagnant standardization efforts ${ }^{140}$ and led to market participants' creation of the so-called Grand Alliance of U.S. HDTV producers and

137. See STEIN, supra note 91, at $30 \mathrm{n} .11$; Licht, supra note 83, at 104 (describing the role of institutions in the coordination game process of standard setting as "dissemination of information"); Picker, supra note 113, at 1286 (finding that interactions among local individuals who successfully adopt a "better norm" will "often lead that norm to be propagated throughout the entire population").

138. See supra Part III.C.

139. See Ahdieh, supra note 6, at 344-45.

140. The purely private sector initiative of the Advanced Television Systems Committee was established in 1982, but did not substantially advance the HDTV standardization process until after the emergence of the FCC's Advisory Committee on Advanced Television Service ("ACATS"). See advanced Television Sys. Comm., FCC, Development of the ATSC DigtTal Television STANDARD, available at http://www.atsc.org/history.html (last visited on Jan. 7, 2004). 
developers. ${ }^{141}$ As this example suggests, public facilitation of communication may often be sufficient to achieve a coordinated outcome. ${ }^{142}$ Where existing or natural linkages do not facilitate efficient interaction, or where coordination game complexities of time and space interfere with such spontaneous linkages, a public signal to invest the necessary resources in a coordinated solution, and structured opportunities to come together, may suffice to allow private parties to achieve efficient outcomes. ${ }^{143}$ Such obstacles, of course, are especially likely to arise amid transition and when a large number of heterogeneous players are presentjust the situation faced in securities market transition. ${ }^{144}$

Finally, law also may favor coordination outcomes generally through its active discouragement, if not exclusion, of noncoordination outcomes. Securities market regulators might do so in securities market transition by increasing confidence and hence the willingness of market players to invest and take risks. One might note, in this regard, the respective analyses of Russell Cooper and Arthur Stein. Each, in a coordination game context, emphasizes the public role in excluding bad outcomes, rather than prescribing a single "right" solution. Thus, Cooper suggests a coordination

141. See id. See also Ellen P. Goodman, Digital Television and the Allure of Auctions: The Birth and Stillbirth of DTV Legislation, 49 FED. COMM. L.J. 517, 522 (1997). Notably, the ACATS and the FCC indicated their receptivity to a jointly developed standard just in advance of the emergence of the Grand Alliance. See Mary Lu Carnevale, FCC Panel Urges New Set of HDTV Tests, WALL. ST. J., Feb. 16,1993 , at B7.

In this and other respects, the HDTV standard-setting process has a distinctly cueing character. See Ahdieh, supra note 6, at 340. See also Joel BRINKLEY, Defining VISION: THE BATTLE FOR THE FUTURE OF TELEVISION, at ix-x (1997) ("Out of [the tumult of Japanese advancement in HDTV development] an extraordinary idea was born, a course of action unprecedented in the history of this nation or probably any other. The United States government started a race, a titanic competition among the major corporations of the world...."). Notably, a cueing-like process involving active participation by both public and private actors was also utilized in the European Union's establishment of its HDTV standard. See id. at 247-48.

142. Antitrust concerns are also likely to be alleviated in this way. Where the government facilitates the coming together of private parties, the state action element should protect the parties from antitrust scrutiny. Meanwhile, the government's presence should also help to minimize the risk of potential anticompetitive results.

143. In this sense, a focal point might be thought of as helping to accelerate the resolution process, and, more generally, as helping to reduce transactions costs, given the real world complexity of the game of securities market transition. See McAdams, supra note 58, at 1701 n.119. See also Licht, supra note 83, at 104 (explaining how institutions can use focal points to reduce transaction costs). Of course, a focal point model cannot completely resolve the problems of heterogeneity, given that some culture or context is needed for the efficacy of focal points. See Sugden, supra note 87, at 546.

144. The cueing function of law in signaling the need for coordinated solutions is especially great during transition. While a stable equilibrium might make such information readily available, that information may be more difficult to assess amid transition. Thus, the law's second cueing function may be more important than its first in stable situations, while the opposite may be true in transition situations. 
game role for government in "supporting confidence in an economy."145 The government may do so, he suggests, through public guaranty funds and similar "confidence building measures." 146 Through the latter, the government discourages disengagement from market processes and from the mechanisms of market coordination. Stein echoes this notion, arguing that institutions directed to coordination problems are not primarily designed to prescribe an outcome, but rather to exclude bad outcomes. ${ }^{147}$ In securities markets, for example, public investment in the markets and in particular market institutions, formal and informal mechanisms of insurance, and the law's reliance on self-regulation might all contribute to such confidence building.

Such an assurance function ${ }^{148}$ might be an important way of understanding law's cueing function, particularly in its first phase, but also in its second phase, where law can essentially be understood as favoring a particularly efficient coordination equilibrium by discouraging less efficient ones. ${ }^{149}$ In addition to confidence-building measures, other mechanisms of law's second-stage cueing function of encouraging efficiency-preferred coordination outcomes can also be identified. Most simply, public authorities can directly promote a particular solution to any

145. COOPER, supra note 84 , at 151.

146. See id. at 126, 150-51. Cooper elaborates on the particular example of deposit insurance in his analysis, characterizing bank-runs as an inefficient coordination game equilibrium. See id. at 12631. To similar effect, he cites the United States' provision of guarantee funds to Mexico during its 1995 currency crisis. See id. at 150.

147. See STEIN, supra note 91, at 41. See also Gillette, supra note 99, at 820 (describing the role of law in providing assurances to facilitate transition). Gillette erroneously relies on law's sanction and enforcement of its articulation of a new standard as the source of law's greater efficacy. See Gillette, supra note 99 , at 820,834 . According to Gillette,

The possibility that government will advocate particular patterns of behavior might go some distance toward providing a centralizing authority for the enunciation of norms, but unless government goes further to provide sanctions, those who are subject to the norm may lack sufficient confidence about the compliance of others to make norms as susceptible to rapid change as common law or statutory law.

ld. As described herein, however, these are not essential.

148. Coordination games are also sometimes dubbed "assurance games," recognizing tbe importance of such confidence to a pareto-efficient resolution of the game. See Licht, supra note 83, at 113. Assurance games are slightly different, or at least have an additional caveat, however, and consequently do not encompass all coordination games. They add a specific element of conflictwhere one player diverges from the pareto-efficient Nash equilibrium, he or she prefers that the other player continue to play that strategy. In the Stag Hunt coordination game, this arises where a player, electing to play a hare strategy, receives a higher payoff if his or her counterpart continues to play a stag strategy. See BAIRD ET AL., supra note 90, at 36 n.l4. See also Licht, supra note 83, at 112-14.

149. This is important in the real world of securities market transition because the relevant game is not $2 \times 2$, with only two potential Nash equilibria, but rather includes a nearly infinite array of coordination equilibria. Once we move beyond a binary game, the exclusion of some equilibria is not conclusive, but remains highly beneficial. 
given securities market coordination problem. For example, the SEC and other securities market regulators might encourage adoption of a particular type of trading mechanism (e.g., the screen-based System A) or generally facilitate reliance on public securities markets, rather than banks.

More broadly, regulatory cues may be used to render a collection of potential coordination solutions, deemed most likely to achieve desired efficiencies, as focal. To this effect, Michael Klausner has proposed a "menu" approach to corporate law in which a number of preferred corporate contract terms are identified and enumerated by legislative authorities. ${ }^{150}$ Whether in the nominal promotion of a particular coordination outcome or in a menu model, however, the essential cueing characteristic of this approach, described in greater detail below, ${ }^{151}$ is that it does not mandate any specific outcome. Rather, it helps facilitate private coordination, presumably at some more efficient point.

Regulatory cues may also highlight particular coordination solutions through the government's role as market participant. ${ }^{152}$ Thus, in the government's choice of a particular network or standard, and hence, coordination equilibrium, it can indirectly signal the preferability of a particular network. ${ }^{153}$ To this effect, public investment through securities markets generally, and through particular securities market structures, can be expected to enhance expectations of those markets' network dominance. This cueing role can be analogized to Randal Picker's description of a public role in promoting efficient norms by "seeding norm clusters."154

Norm seeding is a low-risk strategy. If the government seeds an inefficient cluster, it will die, and little will be lost. If the new norm is superior to the old norm, however, the artificially created norm cluster will thrive and spread. This analysis suggests that the government should embrace test policies or norms or take steps to foster social

150. See Klausner, supra note 28 , at 839-40.

151. See infra Part IV.B.1.

152. See Dan T. Coenen, Untangling the Market-Participant Exemption to the Dormant Commerce Clause, $88 \mathrm{MiCH}$. L. Rev. 395, 400-05 (1989) (discussing the Supreme Court's marketparticipant jurisprudence). Lemley suggests a market participant role for the government even in the initial process of achieving some coordination equilibrium. See Mark A. Lemley, Standardizing Government Standard-Setting Policy for Electronic Commerce, 14 BERKELEY TECH. L.J. 745, 756 (1999) ("[The government] could endorse interoperability in the marketplace ... by refusing to buy or use products that rely on a closed proprietary standard.").

153. In this approach, regulatory cues are usefully tied to Sunstein's conception of "norm entrepreneurs." See Cass R. Sunstein, Social Norms and Social Roles, 96 Colum. L REV. 903, 968 (1996) ("Sometimes law interacts with the efforts of norm entrepreneurs, facilitating or blunting their efforts, and sometimes law ratifies or accelerates_or halts-norm bandwagons and cascades.").

154. See Picker, supra note 113, at 1284-85. 
meanings in particular local contexts as a way of testing whether a superior approach can take root and spread. ${ }^{155}$

Finally, the government might also help to promote particularly efficient coordination outcomes by subsidizing a specific standard in various ways, including direct investment and technical assistance. ${ }^{156}$ In doing so, law signals its view of the particular efficacy of that coordination solution. ${ }^{157}$

\section{B. THE CHARACTER OF REgUlatory CUES}

The basic functions of regulatory cues, as outlined above, constitute a unique role for law. As traditionally understood in law and economics, law serves to shape individuals' incentives to engage in, or desist from, certain conduct. ${ }^{158}$ It does so by means of legal sanctions directed at shaping their payoffs, and hence, their opportunity set. ${ }^{159}$ Regulatory cueing, however, could not look more different.

This is apparent in three central characteristics of regulatory cueing, which distinguish it from law as commonly conceived. First, regulatory cueing is not grounded in the imposition, or even the existence, of any public sanction. It is not even outcome determinative in the ordinary sense. Second, it is expressive in nature, though in an even more basic way than the expressive law that has recently attracted the attention of legal scholars. Finally, it is distinguished from most of what we call law because it involves an inversion and intertwining of public and private roles. These essential characteristics can be considered in turn.

\section{Cues as Nondirective and Nonoutcome Determinative Law}

To begin with, regulatory cues do not rely on the application or threat of public sanction. In this regard, a cueing theory of law in market transition echoes Richard McAdams's conception of legally created focal points as a form of expressive law. As McAdams demonstrates, public

155. See id. at 1285.

156. Russian securities market regulators' provision of technical assistance to NAUFOR's efforts, for example, enabled the NASDAQ-style RTS to coalesce equity investment from multiple markets across the country. See Ahdieh, supra note 6, at 346.

157. See Ronald J. Gilson, Engineering a Venture Capital Market: Lessons from the American Experience 47 (Working Paper, 2002), available at http://ssrn.com/abstract_id=353380. Gilson would have the government invest in venture capital funds at the outset. This clearly serves the second cueing function. Some version of it, however, may also bc important at the first stage.

158. See McAdams, supra note 58, at 1650.

159. See id. 
sanctions are not necessary for law to affect public policy. ${ }^{160}$ McAdams's model, however, relies primarily on the reaction of private actors to lawbased focal points, and hence, on a form of private sanction.

Regulatory cueing, by contrast, does not rely on any form of sanction, public or private. Even more significantly, it does not primarily seek the implementation or adoption of any particular policy choice. It is not, in other words, outcome determinative. ${ }^{161}$ This is essential to the character of regulatory cues. In the standard-setting framework of securities market transition or other network transition, the socially optimal standard is generally unknown. As such, any deterministic intervention of law would be ill-advised. ${ }^{162}$

Most simply, the nonoutcome determinative nature of cueing theory arises from the fact that regulatory cues, even when they nominally press a particular coordination equilibrium, do not dictate that outcome. ${ }^{163}$ Rather, private entities can readily reject an inefficient coordination equilibrium signaled by the government. ${ }^{164}$ They can be expected to do so, moreover, in any case where its inefficiency outweiglıs the resulting coordination benefits. $^{165}$

One can further appreciate the nondeterminism of regulatory cueing by returning to the intertwined regulatory purposes noted above: to narrow

160. See id. at $1650-51$.

161. See STEIN, supra note 91 , at 41 (noting that regulatory solutions to coordination problems do not primarily prescribe outcomes, but rather seek to exclude bad outcomes). This is not to say that the government could not dictate a standard in coordination games if it so chose. See BAIRD ET AL., supra note 90 , at 212 .

162. See Schizer, supra note 43 , at 1573-74.

163. To this effect, Ullmann-Margalit suggests that coordination norms are "used" or "conformed to," rather than complied with. See UlLMANN-MARGALIT, supra note 89 , at 98.

164. See Lemley \& McGowan, supra note 27 , at 545 . In a $2 \times 2$ game, it is even possible that the cueing of the inefficient alternative may trigger private selection of the superior alternative. $C f$. McAdams, supra note 58, at 1665.

165. See Picker, supra note 113, at 1285. A somewhat parallel situation is the result observed in experimental analysis of what are sometimes termed "Ultimatum" games. See generally Werner Guth, Rolf Schmittberger \& Bernd Schwarze, An Experimental Analysis of Ultimatum Bargaining, 3 J. ECON. BEHAV. \& ORG. 367 (1982). In this situation, an allocator (or proposer) proposes how to divide a sum of money. The receiver (or responder) must then choose to either accept or refuse the proposal. If the receiver refuses it, neither player receives any payoff. As little as a penny should be accepted by a rational receiver. Economists, however, have observed a tendency toward a break-point, below which receivers commonly reject the proposal, notwithstanding the consequent loss to themselves. See, e.g., Colin Camerer \& Richard H. Thaler, Anomalies: Ultimatums, Dictators and Manners, J. Econ. PERSP., Spring 1995, at 209, 210; Elizabeth Hoffman, Kevin A. McCabe \& Vernon L. Smith, On Expectations and the Monetary Stakes in Ultimatum Games, 25 INT'L J. GAME THEORY 289, 291-92, 295-96, 299_ 300 (1996); Peter H. Huang, Dangers of Monetary Commensurability: A Psychological Game Model of Contagion, 146 U. PA. L. REV. 1701, 1711-12 (1998). 
the universe of potential outcomes and to provide common knowledgeenhancing information to participants in the relevant coordination game. Considering these in turn, it is apparent that regulatory success is not dependent on, or necessarily characterized by, the selection of any particular strategy. ${ }^{166}$

Starting with cueing's narrowing function, one might note the benefits of focal points and regulatory cues, even when the parties engage in bargaining. In such situations, focal points help facilitate negotiation. Thus, a regulatory cue may serve to create a starting point for bargaining, ${ }^{167}$ creating a common framework-some common knowledge-within which the relevant bargaining can occur. This common framework, in turn, increases the likelihood that a coordinated solution will be reached. The prompted focal point may, for example, be understood to set a default point for division of the relevant contractual surplus. ${ }^{168}$ In securities market linkage, such a role might be essential. Public promotion of a particular network system, for example, might help create a more even playing field for its advocates in negotiations with a dominant market sponsor, such as the NYSE or NASDAQ. Needless to say, regulatory cues of this form do not dictate any particular outcome. ${ }^{169}$

Such regulatory cues do limit the range of potential equilibrium solutions. This involves limited efficiency risk, however, given that all that

166. As this suggests, focal points, and hence, regulatory cues, are effective even where there is some element of conflict in the relevant game, as in securities market transition. See Maarten C.W. Janssen, Focal Points, in 2 DiCTIONARY OF ECONOMICS, supra note 84, at 150, 154; McAdams, supra note 58, at 1672-73. See also Sugden, supra note 87 , at 548 (noting that as long as there is some common interest, focal points are useful). This arises from the fact that in a coordination game, by definition, the "losing" party prefers even the less-preferred coordinated outcome over noncoordination. See Janssen, supra, at 154.

167. See McAdams, supra note 58, at 1676, 1687-88. McAdams suggests that the focal point may be in the nature of a baseline in a negotiation. Further, he suggests that law might be understood in these situations as proposing a "fair" solution. See id. at 1687-88. These ideas originate with Schelling, who suggested such a focal role for a mediator. See SCHELLING, supra note 11, at $143-44$.

168. See McAdams, supra note 58, at 1686-88. Of course, there still may be further cheap talk, but the scope of it is likely to be diminished, given the focal point's suggestion of a default allocation that will limit the extent of potential divergence.

In this sense, some analogy might be made to a Coasean designation of property rights, around which the parties then bargain. In the absence of transaction costs, the particular cue or allocation selected will, admittedly, have welfare consequences. It will not, however, have efficiency consequences. See Devon Garvie, Self-Regulation of Pollution: The Role of Market Structure and Consumer Information, in ORGANIZED INTERESTS AND SELF-REGULATION: AN ECONOMIC APPROACH 206, 208 (Bernardo Bortolotti \& Gianluca Fiorentini eds., 1999).

169. Such a role for regulatory cues in the presence of bargaining is indicative of the role of regulatory cues in the presence of player conflict. See McAdams, supra note 58, at 1686-88. Bargaining, of course, results from just such conflict. 
the public authority signaling the relevant cue must do is come close. Moreover, there may actually be some affirmative benefit to excluding certain solutions, at least where externalities are expected. As noted above, this is likely to be the case in network transition, where the cost of network failure to future market participants is substantial. ${ }^{170}$

A further nondeterministic contribution of the narrowing role of regulatory cues is the potential to overcome network barriers to active market-participant engagement in a particular effort at coordination. ${ }^{171}$ Thus, negotiations concerning a proposed government standard are more likely to be perceived as leading to a dominant network system, and hence, to be joined by the widest array of market participants. Again, such heightened participation does not prescribe outcomes.

The informational role of regulatory cues is similarly nondeterministic. Effective regulatory cues do not consist simply of some designation of a particular equilibrium outcome or standard as focal, but necessarily must incorporate some articulation of reasons for that election. Such articulation, in fact, is their most important contribution. Information on the state of the market, on the efficiency benefits of various potential coordination equilibria, on the costs of various solutions, and even on the expectations and intentions of other market players, can be conveyed through legal cues.

In our game theoretic terms of reference, such information serves to enhance the common knowledge of players in securities market transition. Regulatory cues may help enhance the potential for a coordinated outcome through information on an array of issues-from how alternative linkage systems might operate to current utilization trends of order- versus quotedriven systems, and from the relative size and stability of bid-ask spreads on different markets to the transition programs of various international markets. Cueing may thus place market participants on the same wavelength, moving them closer to common knowledge, and hence, to coordinated expectations and efficient transition. ${ }^{172}$

The benefits of such information are not directed toward any particular solution or outcome, however. For example, information designed to enhance understanding of the relevant measure of the Kaldor-

170. See supra Part II.B.

17I. See supra Part II.B.

172. This task may be an especially critical one amid transition, where there exists no equilibrium from which information can be drawn or where the equilibrium has been disrupted, resulting in a similar effect. Cf. McAdams, supra note 58, at 1701. 
Hicks optimality of any potential coordination equilibrium, or of the potential mechanisms for side payments among players, may help advance the most efficient coordination solution regardless of which particular equilibrium is nominally promoted by the relevant regulatory cue. Regulatory cues are thus better understood as sources of information-as signals of it-than as legal dictates. ${ }^{173}$

\section{Cues as Expressive Law}

Given the noncoercive and nonoutcome determinative orientation of regulatory cueing outlined above, regulatory cues are fairly understood as a form of expressive law. This notion, which has been the subject of growing scholarly attention in recent years, explores ways in which law has an effect not only by what it does, but by what it says. ${ }^{174}$

Scholars of expressive law have articulated a hierarchy of legal functions beyond traditional notions of command-and-control regulation directed toward the adjustment of private incentives. To begin with, law may shape such incentives indirectly through mechanisms of private sanction. ${ }^{175}$ This contrasts with conventional law, which seeks to shape incentives directly. More narrowly, law may serve to alter individuals' preferences. It may do so by signaling a consensus around a particular

173. See STEIN, supra note 91, at $30 \mathrm{n.11}$; Licht, supra note 83, at 104 (describing the role of institutions in the coordination game process of standard setting as "dissemination of information"). See also Robert O. Keohane, The Demand for International Regimes, 36 INT'L ORG. 325, 345-5I (1982). Such information will not necessarily solve the coordination dilemma in any given case. Of course, it may do so, but at a minimum it should enhance common knowledge and thereby increase the potential for a coordination equilibrium to be achieved. See McAdams, supra note 58, at 1681-82.

174. See McAdams, supra note 58 , at $1650-51$. Early contributions to this line of analysis were provided by the work of Lawrence Lessig and Cass Sunstein, who explored the role of law in adjusting social norms. See Alex Geisinger, A Belief Change Theory of Expressive Law, 88 IOWA L. REv. 35, 44-45 (2002) (discussing Lessig's and Sunstein's scholarship). See also Lawrence Lessig, The New Chicago School, 27 J. LEGAL STUD. 661 (1998); Cass R. Sunstein, On the Expressive Function of Law, 144 U. PA. L. REv. 2021 (1996). Other contributions include those of Robert Cooter, who has emphasized law's role in norm internalization, see Robert Cooter, Expressive Law and Economics, $27 \mathrm{~J}$. LEGAL STUD. 585 (1998), and of Alex Geisinger, who focuses on changes in belief as the impact of expressive law, see Geisinger, supra. Finally, I build on one branch of expressive law analysis conducted by Richard McAdams, see McAdams, supra note 58, but he has himself articulated an alternative "attitudinal" theory of law's expressive role. See Richard H. McAdams, An Attitudinal Theory of Expressive Law, 79 OR. L. REv. 339 (2000).

175. Most proximate to the law's ordinary functions is the conception of law facilitating secondor third-party sanctions in a shaming or esteem-based function. See Richard H. McAdams, The Origin, Development, and Regulation of Norms, 96 MiCH. L. REV. 338, 364-65 (1997). See also Scott, supra note 89 , at $1603-04$. This mechanism of legal transition follows from law's facilitation of private social suasion, and even sanction, to bring about conforming conduct. This vision of law can still be understood to be about shaping incentives, however. In this situation, the law's impact on such incentives is simply indirect, working through the intermediary of private actors. See id. 
norm of behavior or by affirmatively altering citizens' values. ${ }^{176}$ Finally, as McAdams has posited, law may alter outcomes simply by shaping individuals' expectations. ${ }^{177}$

Regulatory cueing, because it does not rely on the coercive threat of legal sanction and because it seeks to alter expectations rather than incentives or even preferences, falls well within the category of expressive law. Further, it clearly falls at the mildest end of that spectrum. Beyond its orientation to expectations, this turns on cueing theory's lack of foundation in a norm-based analysis, ${ }^{178}$ unlike most of what has been termed expressive law. As McAdams has argued, the efficient alteration of expectations in coordination games requires no normative foundation.

176. Law may do so by signaling a consensus around a particular social norm. Examples of this pattern might include the rejection of racial discrimination by social norms, see Eric A. Posner, Symbols, Signals, and Social Norms in Politics and the Law, 27 J. LEgal STUD. 765, 789 (1998), and the abhorrcnce of drunk driving, see Paul H. Robinson \& John M. Darley, The Utility of Desert, 91 Nw. U. L. REV. 453, 473 (1997). In this case, law's function might be understood as informative in nature. It advertises a heretofore unarticulated moral consensus. This pattern also ultimately turns on the individual subject's place in the collective and on his or her desire to conform with its conventions for reasons at least analogous to those produced by private sanctions.

Law may also change preferences by actually changing beliefs. See Sunstein, supra note 153, at 907 (describing the public role in "norm management"); Talley, supra note 99, at 2020 n.150 (noting law's role in altering prefercnces). This is distinct from the notion, discussed above, that law serves to change social meaning. Hcre, law produces internalization and thus truly changes preferences. See Scott, supra note 89, at 1624 . From this perspective, law's function might be conceived as not merely informative, but also educational in nature. Likewise, there is no change in incentives, or constraining of opportunities, because altered preferences now undermine the desire to pursue certain lines of action. See id. at 1605, 1621.

177. Scott suggests a gradation from first-order sanctions by the state, to second-order sanctions by second or third parties, to third-order self-sanctioning by means of internalization and guilt. See Scott, supra note 89 , at 1603-04. As one progresses down this hierarchy, norms become increasingly central to the analysis. It also bears noting that although the emphasis herein is on commercial norms, these are not different in kind from social norms. Thus, Klausner conneets some of the same pieces discussed here in the context of commercial norms. See Klausner, supra note 28. See also Jody S. Kraus, Legal Design and the Evolution of Commercial Norms, 26 J. LEGAL STUD. 377, 379 n.5 (1997) (relying on Klausner).

Questions of function tied to the analysis of expressive law arise with cueing in coordination games, including securities market transition. Thus, Ullmann-Margalit raises the question of whether a public solution to a coordination problem-in her case, a road sign stating "KEEP RIGHT"-is most meaningfully understood as "an order," "a prescription," or "an advice." See UlLmanN-MARGalit, supra note 89 , at 90 . It is appropriate, in this light, to clarify the place of regulatory cues within the hierarchy of expressive law.

178. See McAdams, supra note 58, at 1666 ("[M]oral authority or legitimacy of law is not necessary to create a focal point."). Hence, the analysis of expressive law commonly has been tied to evaluations of what norms are, what they mean, and how law might change them. See Scott, supra note 89 , at 1622 . 
Law's regulatory cueing function is about facilitation. ${ }^{179}$ Such facilitation does not turn on whether the action signaled is consistent with existing norms. Hence, even a morally bankrupt and disconnected public authority may serve a cueing function. ${ }^{180}$

In fact, the proposed cueing theory posits an even more restricted role for law than McAdams's similar expectations-based model of expressive law. In McAdams's model, the government's creation of a focal point is intended to favor its particular choice. McAdams's central point is that law, in the form of focal points, can "dictate" outcomes without reliance on any coercive sanction. Here, on the other hand, the relevant cue is not intended to dictate the prescribed choice; instead, it is designed to facilitate some coordination equilibrium, rather than any specific one. In this sense, cueing regulation is expressive law in the truest sense.

\section{The Public/Private Distinction in Regulatory Cues}

The final important characteristic of regulatory cueing is its complex intertwining of public and private. Regulatory cueing, in fact, might arguably be said to involve some direct inversion of public and private functions. ${ }^{181}$

A cueing theory of law in securities market transition recognizes that focal points can be created by nongovernmental third parties. ${ }^{182}$ Thus,

179. To similar effect, law's expressive function has been characterized as cheap talk. Cheap talk, it will be recalled, is nonbinding speech. Regulatory cues thus provide nonbinding yet eminently useful signals of expected private behavior.

180. See McAdams, supra note 58, at 1682.

181. Regulatory cueing, in this sense, is closely related to a recent body of administrative law scholarship focused on the growing difficulty of drawing a sharp line between public and private regulatory functions. See, e.g., PRIVATIZATION AND the Welfare STATE (Sheila B. Kamerman \& Alfred J. Kahn eds., 1989); Jody Freeman, The Contracting State, 28 FLA. ST. U. L. REV. 155 (2000) (describing the routine contracting out of traditionally public functions to private entities by federal, state, and local governments); Jody Freeman, The Private Role in Public Governance, 75 N.Y.U. L. REv. 543-44 (2000) [hereinafter Public Governance] (noting the private performance of legislative and adjudicatory functions). The emphasis herein is on the exceptional forms of public regulation of private groups. In contrast, the foregoing body of work has focused on the interaction between public and private in modern regulation.

182. See McAdams, supra note 58, at 1663-64; Picker, supra note 113, at 1285 . UllmannMargalit points to precedent as a source of focal points, although this approach necessitates at least some recurrence (e.g., a two-play game). See UlLMANN-MARGALrT, supra note 89, at 84. She also refers to agreement as a source of focal points, which is evaluated here as communication. See id. Contextual sources of focal points, arising from the relevant payoffs and running across coordination games generally, have also been proposed. See BAIRD ET AL., supra note 90 , at 39. Most significantly, Harsanyi and Selten have posited that pareto-superior equilibria may be focal. See COOPER, supra note 84, at xii; JoHn C. HARSANYI \& REINHARD SELTEN, A GENERAL THEORY OF EqUILIBRIUM SELECTION IN GAMES 356 (1988). Experimental evidence, however, has not confirmed this intuition. See COOPER, 
Schelling suggests that a newspaper's picture of the Empire State Building on the date his imagined friends are separated in New York City might help solve their Meeting Place dilemma. ${ }^{183}$ While nonpublic third parties will not always be the best source of focal points, ${ }^{184}$ it is at least clear that functions such as the provision of information and the facilitation of interchange are not uniquely public functions. Regulatory cueing thus makes public entities look a great deal more private.

supra note 84 , at $2-3$. In the alternative, the notion of risk dominance has been suggested. See id. at xii, 2; HARSANYI \& SELTEN, supra, at 82-90, 355-57. Cf. Mahoney \& Sanchirico, supra note 111, at 15 (highlighting the potential segregation of risk-dominant and pareto-optimal results). This theory argues that, in essence, the least risky solution may be focal. This is sometimes described as a "minimax" solution because it involves players maximizing their minimum gain. See STEIN, supra note 91 , at 30 .

183. In fact, a form of focal point might even arise through the players' own actions, even if not necessarily through their oral communication. To this effect, some have analyzed the issue of what happens when parties label themselves as serving a focal function. See Sugden, supra note 87.

184. For several reasons, nonpublic third parties may be relatively less effective sources of focal points. First, they may be less able than law to control for the presence of externalities. $C f$. Sugden, supra note 89 , at 492 . Second, they may be more susceptible to various potential inefficiencies. See Gillette, supra note 99, at 815 (arguing that private-based norms, as distinct from the common law or statutory law, may be more susceptible to lock-in, and hence, less likely to efficiently transition). Third, where the relevant third party has some vested interest in the outcome, he or she may have his or her own cheap talk issues, as one would expect of any third party ready to invest in resolving the game of securities market transition. Finally, insufficient information or sufficiently elevated transaction costs may interfere with the emergence of any private solution. See id. at 834-35 (noting that even pure coordination games may not readily be solved without law if information is poor or transaction costs are high). As Eric Posner puts it, private coordination may be more dependent on the "preexistence of focal points," which law can create. See Posner, supra note 83, at 1719. For this reason, law may be a more expeditious mechanism for the emergence of focal points, especially in the complex real-world coordination game of securities market transition. See McAdams, supra note 58, at 1701 \& n.119.

To this effect, Stephen Krasner suggests the particular need for institutional regimes in the evaluation of what he characterizes as highly complex coordination games in international telecommunications. See Krasner, supra note 102, at 337 (noting the importance of institutional arrangements in resolving coordination problems). "The primary motivation for establishing international regimes for international telecommunications has been to solve coordination problems that have distributional consequences-not to address problems of market failure." Id. at 362. Krasner thus suggests that among what he characterizes as "four possible configurations of interests," institutional arrangements, or regimes, are irrelevant to (1) harmony games, in which each player's rational incentives, acted on without regard to the strategy of his or her counterpart, produce maximum individual and social welfare, and (2) zero-sum games, in which any gain to one player is a loss to the other. On the other hand, institutions are relevant to both Prisoner's Dilemma and coordination game strategic situations. See id. at 337-38.

More generally, a cueing role for law in securities market transition recognizes that even if regulatory cues do not produce the Kaldor-Hicks efficient result, they may produce a better result than will a private attempt at coordination, given the network obstacles with which our analysis began. The choice is not between the potentially inefficient coordination outcome of regulatory cueing and an efficient private process of coordinating expectations; rather, the relevant comparison is between the potentially inefficient coordination outcome of regulatory cueing and the potentially inefficient coordination outcome of a private regime, as well as the possibility of complete noncoordination. 
Conversely, private entities in the cueing process engage in behavior of a public character. Conventionally, public policy is defined at some level of regulatory detail and thereafter executed by public authorities. The SEC, for example, prescribes clearly defined categories of securities disclosure, coordinates the collection and dissemination of those disclosures, and enforces the collective body of rules that follow from these obligations. With regulatory cueing, however, the pattern is different. While the relevant regulatory agency favors a coordination outcome generally, and sometimes even a particular one, the precise character of the regulatory goal pursued is left to private entities. ${ }^{185}$ More significantly, market actors almost entirely determine whether coordination is achieved, by what mechanisms, and in what precise form. Ordinarily, public entities would be expected to do each of these through the mechanism of law. In the network coordination environment of securities market transition, however, one observes public action of a less comprehensive nature. ${ }^{186}$

While a cueing theory of law does involve the nominally familiar situation where private entities cannot do it alone, but require public intervention, ${ }^{187}$ the nature of such intervention is fundamentally different in cueing theory. The network effects that give rise to law's asserted role in securities markets and other networks, including both size and tipping effects, are uniquely issues of market transition, whether creation or restructuring. ${ }^{188}$ They do not, on the other hand, have immediate implications for stable market equilibria. In the coordination game literature, Nash equilibria are viewed as self-enforcing and stable once reached, but may require intervention to take hold in the first place. ${ }^{189}$ In network transition, likewise, public action serves to overcome size and

185. A cueing function for law thus involves truly limited government. See Licht, supra note 83, at 127 (charting the limited functions of institutions in coordination games). Cf. David V. Snyder, Private Lawmaking, 64 OHIO ST. L.J. 371 (2003) (analyzing the role of private entities in creating "law").

186. Cf. Snidal, supra note 82, at 932 ("Any role for centralized authority in coordination problems is likely to be less concerned with enforcement than with codification and elaboration of an cxisting or latent convention and with providing information and communication to facilitate the smooth operation of the convention."). McAdams suggests that in coordination games of transition, limited government action is required. See McAdams, supra note 58, at 1652. Cf. Hay \& Shleifer, supra note 121 , at 400 .

187. Cf. Posner, supra note 83, at 1719.

188. Aviram has thus described the regulatory effectiveness of networks as distinct from public entities or the parties to individual transactions. See Aviram, supra note 46. The network tools of such regulation include control mechanisms, switching mechanisms, information mechanisms, and exclusion mechanisms. See id. at 18.

189. See supra Part III.B. 
tipping effect barriers to private regulation, after which private regulation can be effective without further need for law.

Thus do we have an episodic role for regulatory cues in securities market transition, facilitating market creation or restructuring, but lacking a regulatory role beyond this initial phase. ${ }^{190}$ Ronald Gilson's vision of the public role in "engineering" venture capital markets is analogous. In Gilson's scheme, as with the proposed cueing theory, the "government act [s] to create a market in which it has no long-term role."191

This suggests an interesting connection to the social norms and private regulation literature. Initiated by Robert Ellickson's seminal work, ${ }^{192}$ the study of private regulation, including variously formed "private legal systems," "93 has been an area of rapidly expanding scholarly interest. ${ }^{194}$ A growing number of scholars have begun to examine how private groups function and regulate behavior in a variety of areas.

As characterized above, once networks and coordination equilibria emerge, they exhibit the same stability that has been observed in private legal systems. Thus, a cueing theory of law, rather than challenge the premises of the study of private legal systems, may directly complement it. Regulatory cueing might be conceived to play a facilitative role in the creation of at least some private legal systems, including securities markets. ${ }^{195}$ Cueing theory thus suggests that when an industry is

190. Beyond this phase, private regulation can be expected to suffice. See Ahdieh, supra note 6, at 337 .

191. See Gilson, supra note 157 , at 38. Alice Amsden's macroeconomic analyses of market transitions in East Asia, as well as central and eastern Europe, favor an analogous interplay of public and private in the early stages of transition to a market economy. See AMSDEN ET AL., supra note 8.

192. See Picker, supra note 113, at 1286 (citing ROBERT C. ElLICKSON, ORDER WITHOUT LAW: How NeIGHBORS SETTLE DISPUTES (1991)).

193. See Omri Ben-Shahar \& Lisa Bernstein, The Secrecy Interest in Contract Law, 109 YALE L.J. 1885, 1923 (2000) (discussing merchant-run private legal systems, in which "disputes are resolved in trade-association-run arbitration tribunals that operate under substantive and procedural rules adopted by the merchants whose transactions they govern").

194. Although private legal systems have existed for some time, see Mark D. West, Private Ordering at the World's First Futures Exchange, 98 MICH. L. REv. 2574, 2574 (2000) (noting that creation of the Japanese Dojima Rice Futures Exchange began in the late seventeenth century), and many industries rely on them, see The New Chicago School: Myth or Reality?, 5 U. CHI. L. SCH. ROUNDTABLE 1, 5 (1998) (describing various industries that have adopted private legal systems, including the diamond, rice, tea, and independent film industries), scholars have only recently begun to recognize their importance.

195. Supporting this potential role for regulatory cues in establishing private legal systems, Amitai Aviram has observed the seeming barriers to the spontaneous formation of private legal systems. See Amitai Aviram, The Paradox of Spontaneous Formation of Private Legal Systems, 22 YALE L. \& POL'Y REv. (forthcoming 2004). Contrary to the Coasean prediction, Aviram suggests a chicken-andegg problem that prevents a private legal system from providing costly enforcement services until it has 
characterized by network effects, regulatory cues may help to make it safe for private law. In the literature of private legal systems, many have spoken of order without law. Cueing theory, however, posits order in the aftermath of law.

Network-related standard-setting processes, technological or otherwise, are strongly suggestive of cueing function's grounding in joint public and private action. By way of example, the work of the International Telecommunications Union, and even its formation, are suggestive of a public role in standard setting, but one closely tied to the efforts of nonstate actors. ${ }^{196}$ The International Organization for Standardization, with its interface of public and private agencies, is yet another example. Perhaps the most compelling case study, however, has been the standardization efforts in HDTV technology. ${ }^{197}$ There, even efforts hailed as significantly driven by private initiative, such as the European Launching Group, can ultimately be traced back to some initial public impetus. ${ }^{198}$

Taking into collective consideration the several core characteristics of regulatory cues that have been outlined, regulatory cueing may best be understood to stand somewhere between the realms of law and convention. Clayton Gillette's identification of the "absence of a centralized mandate"

already established itself. Notably, he posits that effective private legal systems arise in network environments and, more specifically, evolve out of looser networks (e.g., social networks), the low enforcement costs of which allow them to form spontaneously. See id. at 21-23. See also id. at 48-49 (noting that the dynamics of the Meeting Place game are characteristic of social networks and other low-cost enforcement networks). Aviram thus posits an alternative potential mechanism of transition to private regulation that does not rely on regulatory cues. He starts, however, with a similar appreciation of the barriers to spontaneous transition.

196. See Christopher T. Marsden, Cyberlaw and International Political Economy: Towards Regulation of the Global Information Society, 2001 L. REv. M.S.U.-D.C.L. 355, 378 (2001) (indicating "no doubt of the fact that nonstate actors are intimately involved in the formerly state-controlled process of rule and standard setting for the Internet and telephony").

197. See supra notes $140-41$ and accompanying text.

198. See Marsden, supra note 196, at 392-93 (noting the foundation of private efforts in decisions by German and British officials). Cf. 1 U.S. GOV'T WORKING GROUP ON ELEC. COM. ANN. REP. 20 (1998) (on file with author) (describing the governmental role in facilitating standard-setting processes). A wide array of other standard-setting organizations operating at the margins of public and private regulation are described in Snyder, supra note 185, from the American Law Institute and the National Conference of Commissioners on Uniform State Laws, to the NYSE, the International Chamber of Commerce, and the New York Diamond Dealers Club. See generally Marc A. Oshan, StandardsMaking Organization and Rationalization of American Life, 34 SoC. Q. 319 (1993) (describing the development and role of various standard-setting organizations, including the American Standards Association, the National Bureau of Standards, and the American National Standards Institute). 
as the distinction between law and norms therefore seem inapposite. ${ }^{199}$ Instead, regulatory cues appear to combine the two. While norms ultimately solve the coordination problem in securities market transition, those norms are facilitated by law. Government, in essence, becomes what Gillette describes (borrowing from Sunstein ${ }^{200}$ ) as a "norm entrepreneur," "subsidizing the costs of signalling appropriate behavior and generating a reputation sufficient to warrant that the signals they send will be followed by recipients."201

Regulatory cueing similarly challenges Ullmann-Margalit's categorization of coordination norms as either conventions or decrees, based on whether they come from an identifiable institutional source. ${ }^{202}$ The proposed cueing function suggests a third type of coordination norm. Although statutory in nature and issued by an "endowed authority," like Ullmann-Margalit's decrees, ${ }^{203}$ regulatory cues are not themselves the relevant norm, but a mechanism to create it. Unlike decrees, moreover, they do not have any dispositive legal sanction behind them. ${ }^{204}$

Cueing theory thus posits the limitations of both law and norms in securities market transition and network transitions generally. It suggests that, in such cases, law's exceptional goal is to facilitate the emergence of norms. In this way, cueing theory seeks to balance the conformity of law with the diversity of norms. ${ }^{205}$

$$
* * *
$$

Although not identified as a conceptually distinct function of law, some have described a cueing-like role for law in the creation and shaping of markets. As mentioned above, Gilson has evaluated an analogous pattern in the creation of venture capital markets. Gilson identifies a "missing market" situation (a form of coordination failure), ${ }^{206}$ paralleling the network obstacles to the emergence of efficient markets herein. In the face of a missing market, which he terms a "simultaneity" problem, ${ }^{207}$

199. See Gillette, supra note 99 , at 834 .

200. See Sunstein, supra note 153, at 909, 929 (defining "norm entrepreneurs").

201. See Gillette, supra note 99 , at 835.

202. See ULLMANN-MARGALIT, supra note 89, at 97.

203. See id.

204. See id. at 99 .

205. See Klausner, supra note 28, at 837-38.

206. See Walter P. Heller, Equilibrium Market Formation Causes Missing Markets, in MARKETS, INFORMATION, AND UNCERTAINTY, supra note 68, at 235.

207. See Gilson, supra note 157 , at $4-5,37$.

A venture capital market requires the simultaneous availability of three factors, the provision of any one of which is contingent on the availability of the other two. A venture capital 
Gilson observes a pattern of public intervention to facilitate the creation of venture capital markets. ${ }^{208}$ On this foundation, Gilson elaborates a limited model of public facilitation-what he calls "engineering" a market-that looks similar in nature to regulatory cueing as described herein. ${ }^{209}$

In the securities markets themselves, regulatory cueing-like models have been pressed. Steven Wallman has suggested a regulatory approach by the SEC that is more open-ended and conceptual, less reactive, and less detailed and recurring than the Commission's present regulatory model. ${ }^{210}$ Further, Wallman highlights a useful example of cueing in U.S. securities markets' transition to decimal pricing. Wallman notes that subsequent to his own call for prompt decimalization, the U.S. House of Representatives adopted a resolution that, upon adoption, would have mandated a conversion to decimals. ${ }^{211}$ Promptly after passage of the nonbinding resolution, however, the NYSE announced its intention to move to decimals "as soon as possible and . . no later than the year 2000." "12

David Schizer's concept of "benign restraint" deserves a similar note. Considering the market structure questions at issue in securities market transition, including in particular the SEC's National Market System project, Schizer suggests a restrained model of regulation in which much regulation is left to the market itself. ${ }^{213}$ In certain cases, however, Schizer

market requires entrepreneurs, investors with the funds and the taste for high-risk, high return investments and... a specialized financial intermediary to serve as the nexus of a set of sophisticated contracts.

Id. at 37. To this effect, Gilson suggests an analogy to the credit card industry. See id. at 37-38.

208. See id. at 5, 39-46 (evaluating examples).

209. See id. at 46. Gilson speaks of "engineering" markets, while I use the term "making" markets. Compare id. at 36, with Ahdieh, supra note 6. Yet Gilson is similarly identifying an essential role for public entities in the creation of certain types of private markets. See Gilson, supra note 157, at $5-6,36$ ("Can the government act as the cngineer in creating a system that is driven by private ordering?").

210. See Steven M.H. Wallman, Competition, Innovation, and Regulation in the Securities Markets, 53 Bus. LAw. 341,348 (1998). Specifically, Wallman asserts that "regulators increasingly need to ensure that it is the market that leads, not the regulators." $I d$.

211. See id. at 357.

212. Id. To analogous effect, Cooper speaks of a governmental role in macroeconomic coordination games, such as the securities market transitions of interest herein, that does not rely on public action at all. Rather, he argues, its essence is a commitment to action. See COOPER, supra note 84 , at 126 . The same can be said of regulatory cueing. This view of what is required of law to be effective naturally has consequences for our evaluation of the efficacy of state action. "Thus governments may appear to be doing "nothing' when, in fact, they are quite successful." See id. As we will see below, such an analysis is precisely appropriate in the context of the National Market System. See infra Part V.B.

213. See Schizer, supra note 43, at 1554 ("Faced with a technological revolution, a heated debate over market structure, and a marketplace of investors with diverse preferences, the SEC has so far 
describes a role for the SEC in encouraging or facilitating private actionjust the task of regulatory cues. ${ }^{214}$

Perhaps most interesting is Klausner's development of a network effects theory of corporate law. In the face of potential network inefficiencies, Klausner proposes to replace the contractarian paradigm's reliance on untailored default terms with a menu of open-ended tailored terms. $^{215}$ In this way, Klausner argues, the risks of either suboptimal standardization or suboptimal variety, as well as the risks of network lockin, can be minimized. As with the regulatory cueing theory proposed here, such menus would not eliminate the risk of suboptimality, but would go a long way toward reducing it. ${ }^{216}$

\section{FINDING THE CUES IN SECURITIES LAW: MARKET STRUCTURE, THE NATIONAL MARKET SYSTEM, AND SELF-REGULATION}

Having described the parameters of a cueing theory of law's role in network transition, we can turn to its particular applications within the securities regulation regime. Generally, securities regulation as a discipline and body of law has failed to appreciate the essential need to regulate securities market structure, instead leaving the market's form and evolution entirely in the invisible hands of the market itself. In addition to challenging this mindset and rethinking what is meant by, and encompassed within, securities regulation, cueing theory also supports a reassessment of the SEC's only major effort to regulate market structurethe widely derided National Market System. From a cueing perspective, the National Market System regulatory response to what has been described as "the most prolonged and severe crisis in the securities industry" since the Great Depression ${ }^{217}$ may have been far more successful

decided not to decide. It has not designated a preferred execution system and instead has relied on competition within the private sector.").

214. The SEC's creation of its Office of International Trading and Technology, along with that Office's various recommendations on issues of automation risk in the aftermath of the October 19, 1987 stock market crash, constitutes one example. See id. at 1558.

215. See Klausner, supra note 28, at 832-33, 839-40. Furthermore, Klausner's menu items would not be defined simply by reference to common corporate contracting practices, but would involve some more searching review from a network perspective. See id. at 839-40.

216. See also Ian Ayres, Making a Difference: The Contractual Contributions of Easterbrook and Fischel, 59 U. CHI. L. REV. 1391, 1403-08 (1992) (making an argument similar to Klausner's).

217. See Joel Seligman, The TRANSFormation of Wall StREET: A History of THE SECURITIES AND EXCHANGE COMMISSION AND MODERN CORPORATE FINANCE 450 (rev. ed. 1995) (quoting STUdY of UNSAFE AND UNSOUND PRACTICES OF BROKERS AND DEALERS: REPORT AND 
than is commonly acknowledged and may even constitute a useful model. Finally, a cueing analysis of securities law's familiar reliance on selfregulation also suggests possible explanations for that pattern, as well as criteria for its extension to other regulatory arenas.

\section{A. REgulating MARKET STRUCTURE}

Regulatory cueing is, by definition, about the design and form of the market-what I have termed "market structure." 18 It responds to the implications of network effects for market form and particularly for the evolution of that form. Thus, it seeks to facilitate efficient structural transition. This transition includes both the creation of markets, as in the emerging markets of central and eastern Europe, and the restructuring of established markets through the modernization of existing technologies and the development of more extensive market linkages. ${ }^{219}$

But this conception constitutes a dramatic departure from what securities regulation is commonly understood to mean. In the United States, securities law almost completely disregards the institutional design of the market. The primary use of banks or public securities markets for corporate finance, a preference for auction or dealer market structures, the extent of reliance on electronic trading and communications mechanisms, and like issues are entirely beyond the conventional purview of the SEC and related agencies. ${ }^{220}$

Instead, securities regulation has focused primarily on what one author has termed a "sunlight" regime. ${ }^{221}$ Most significantly, this includes the

RECOMMENDATIONS OF THE SEC, H.R. DOC. No. 92-231, at 1 (1971) [hereinafter STUDY OF UNSAFE AND UNSOUND PRACTICES]).

218. My use of the term "market structure" is more closely tied to the notion of "market microstructure" than to references to "market structure" in the regulated industries literature. See supra note 13. The latter focuses primarily on the economic structure of the market rather than on its organizational and institutional forms. Likewise, I do not intend "market structure" to refer to the formal structures of the securities markets. The emergence of hedge funds in recent years, the heavy reliance on mutual funds and related forms of collective investment in modern securities markets, and the like are thus beyond the network analysis I propose.

219. See Ahdieh, supra note 6.

220. Securities regulation has not been concerned witb the "shaping and enforcement of industrial policies," see JAMES M. LANDIS, The ADMINISTRATIVE PROCESS 22-23 (1938), true regulatory functions, but ones that have come to be identified as economic and political, rather than legal, in nature. See Roberta S. Karmel, The Market 2000 Study, N.Y. L.J., Oct. 15, 1992, at 3.

221. See Walter Werner, The SEC as a Market Regulator, 70 VA. L. REV. 755, 755 (1984). In contrast with Werner's division of SEC authority into sunlight and regulatory (i.e., market structure) questions, David Lipton suggests three categories of SEC authority: (1) response or pure oversight control, (2) direct control, and (3) indirect control. See David A. Lipton, The SEC or the Exchanges: Who Should Do What and When? A Proposal to Allocate Regulatory Responsibilities for Securities 
SEC's disclosure and antifraud policies. Since its creation, the SEC has emphasized these policies to the near complete exclusion of questions of market design. ${ }^{222}$ This pattern is widely acknowledged in the SEC's own characterizations of its role, ${ }^{223}$ in decisions of the Supreme Court, ${ }^{224}$ in scholarly analyses of securities laws, ${ }^{225}$ in textbook characterizations of them, ${ }^{226}$ and in professional commentary in the field. ${ }^{227}$

Markets, 16 U.C. Davis L. REV. 527, 531-35 (1983). He further identified three types of regulatory activities: (1) rulemaking and order granting, (2) discipline, and (3) policy setting. See id. at 536.

222. The SEC has been unwilling to engage issues of market structure, including, for the most part, the emergence of new technologies and their impact on the securities markets. See Werner, supra note 221, at 756, 767. Considering this pattern, Steve Thel has criticized the SEC's and the Supreme Court's narrow interpretation of SEC powers under the Securities Exchange Act ("SEA"), particularly section 10(b). While the latter encompasses a disclosure orientation, Thel suggests it does much more: "In addition to requiring security issuers to disclose information, the Exchange Act puts the government in control of stock market credit and the activities of market institutions." Steve Thel, The Original Conception of Section 10(b) of the Securities Exchange Act, 42 STAN. L. REV. 385, 390 (1990) (internal footnotes omitted). See also id. at 461 ("[Slection 10(b) was designed to give the SEC plenary power over the stock market."). The SEC has not exercised such a function, however.

223. See SEC, THE INVESTOR'S ADVOCATE: HOW THE SEC PROTECTS INVESTORS AND MAINTAINS MARKET 1NTEGRITY ("[T]he SEC is concerned primarily with promoting disclosure of important information, enforcing the securities laws, and protecting investors...."), at http://www.sec.gov/about/whatwedo.shtml (last visited Jan. 7, 2004). The "SEC [has] tacitly declared full disclosure to be the primary interest of the public in the securities markets." Thel, supra note 222, at 462 . The SEC has also had occasion to explicitly say that it is not engaged in "economic regulation," but is instead an "enforcement agency." See Walter Werner, Adventure in Social Control of Finance: The National Market System for Securities, 75 COLUM. L. REv. 1233, 1261, 1267 (1975). Finally, the SEC's relative disinterest in market structure regulation is also evident in its failurc to think about market structure issues systematically. See Polly Nyquist, Failure to Engage: The Regulation of Proprietary Trading Systems, 13 YALE L. \& POL'Y REV. 281, 291 (1995). Recent SEC analyses in this direction can be noted, but they have been notable aberrations.

224. See, e.g., SEC v. Capital Gains Research Bureau, Inc., 375 U.S. 180, 186 (1963) (stating that "substitut[ing] a philosophy of full disclosure for the philosophy of caveat emptor" is the "fundamental purpose" of securities laws). See also Thel, supra note 222, at 386-90 (discussing the Supreme Court's conception of section 10 (b) of the SEA).

225. See Nyquist, supra note 223, at 291; Thel, supra note 222, at 391-92, 461 (describing the SEC's failure to focus on prices, and hence on the public interest, as opposed to the interests of market participants); Werner, supra note 223, at 1254, 1261 (describing the SEC as an "enforcement agency").

226. See, e.g., Thomas lee hazen, The Law of Securtties Regulation (3d ed. 1996). According to David Ratner and Thomas Hazen, securities regulation is "concerned with the regulation of people and firms engaged in that business, to assure that they do not take advantage of their superior experience and access to overreach their non-professional customers." DAVID L. RATNER \& THOMAS LEe HAZEN, SeCuRTIES REgulation IN A NutShell 2-3 (7th ed. 2002). Furthermore, their descriptions of the elements of securities regulation do not include an element of the regulation of market structure, even though they discuss the "regulation of the securities business." ld. at 179. The same is true of Loss's securities regulation treatise, in which chapters nine and ten deal with certain market regulations, but not with market structure regulation. See 3 LoUIS Loss, SECuRITIES Regulation 1421 ( $2 \mathrm{~d}$ ed. 1961). See also 5 Louis Loss \& Joel Seligman, SeCurtties Regulation 2121 (3d ed. 1990).

227. See, e.g., Sam Scott Miller, Elizabeth Coley \& William O'Brien, Tethering Technology: The SEC's Market Structure Concept, 9 INSIGHTS 7, 11 (1997) (criticizing possible SEC intervention in 
Securities regulators' avoidance of questions of market structure, and hence, of its transition, is not entirely surprising. First, questions of transition are widely seen as political and economic rather than regulatory issues. ${ }^{228}$ Second, there is a visceral sense that market structure is appropriately the province of private industry, not government. ${ }^{229}$ Finally, perhaps for these reasons, market structure resists direct regulation. ${ }^{230}$ Especially in the face of widespread praise for its traditional work, ${ }^{231}$ these several objections to market regulation might be expected to weigh heavily on the SEC. ${ }^{232}$

This is not to say that the SEC has completely avoided the regulation of market structure. Its indirect regulation of brokers, dealers, and investment advisers is a form of market regulation. ${ }^{233}$ Likewise, as I will highlight below, one can identify episodes of market structure regulationincluding the National Market System drive of the early 1970s and recent interest in market structure issues-driven by the emergence of new trading technologies. ${ }^{234}$ For the most part, however, the SEC's efforts have been more smoke than fire. ${ }^{235}$ While there has been much rhetoric of the "public

market structure issues and stating that " $[\mathrm{t}] \mathrm{he}$ Commission appears ready to embark on a dangerous path, relinquishing its role as preserver of market competition in favor of dictating the development of market technology and structure").

228. See Karmel, supra note 220, at 3.

229. See Joel Seligman, The Future of the National Market System, 10 J. CORP. L. 79, 131 (1984) (quoting former SEC chairperson Harold Williams as saying that the initiative in the design and implementation of the system should be left to private industry).

230. See Bevis Longstreth, The SEC After Fiffy Years: An Assessment of lts Past and Future, 83 COLUM. L. REV. 1593, 1595 (1983) ("On the other hand, as we shall see, fundamental issues of market structure generally have not proven susceptible to administrative resolution."). See also id. at 1598 (emphasizing the need "to distinguish the Commission's obvious success in stimulating strong selfregulation by the Exchange (and also by the other securities exchanges and the NASD) from the Commission's apparent failure to respond boldly to the fundamental issues of market structure") (internal footnote omitted).

231. See Werner, supra note 221 , at 755.

232. See id. See also Karmel, supra note 220, at 3-4. Given the SEC's own focus on disclosure, it is not surprising that it has come to be perceived as the SEC's primary contribution.

Given the public record of the work of the SEC, the overwhelming importance of the disclosure and antifraud provisions in private securities law practice, and the composition of the caseload faced by the courts, it is not surprising that a "full disclosure" emphasis is usually attributed to the securities laws.

Thel, supra note 222, at 462 (internal footnote omitted).

233. See Stephen Choi, Regulating Investors Not Issuers: A Market-Based Proposal, 88 CAL. L. REV. 279, 281-82 (2000).

234. See infra Part V.B.

235. See infra Part V.B.2. 
interest," for example, SEC rules continue to be primarily directed to the protection of market participants. ${ }^{236}$

One might note the existence of market structure regulation by SROs in the securities markets, from the NYSE to the National Association of Securities Dealers ("NASD"). The latter bodies are very much involved in issues of market structure, form, and function, including issues of system architecture, incorporation of fragmented market share, and the like. This is a necessarily unusual conception of market structure regulation, however, as the market structure activities of the NYSE and NASD arise primarily from their role as market participant, rather than market regulator. ${ }^{237}$ They are naturally involved in structuring and restructuring themselves, but their efforts are driven by market forces, not regulatory concerns. Consequently, this regulation is not systemic, extending across markets, nor is it shaped in any meaningful way by the public interest.

The pattern of SEC disregard of market structure regulation has not gone without criticism. ${ }^{238}$ For the most part, however, the failure to

236. See Werner, supra note 223, at 1254. In part, this pattern arises from Congress's selective removal of the actual public interest policies from the SEA. See id.

237. See, e.g., Mark Borrelli, Market Making in the Electronic Age, 32 Loy. U. CHI. L.J. 815, 827 (2001) (finding that "[t]here has always been an inherent conflict in the self-regulatory system, as the members of a for-profit industry are called upon to rein in any propensity for illegal or unethical conduct that might be spawned by the profit motive"); Poser, supra note 108, at 535-36 (identifying the conflict of interest inherent in having the exchanges and NASD be operators of a market and selfregulators).

238. Among the most comprehensive critics is Walter Werner, who has long emphasized the SEC's failure to exercise its "economic authority" and to truly regulate the securities markets. See Werner, supra note 223, at 1254 . The SEC, Werner argued, wrongly emphasized error correction over error prevention. See id. at 1246. In Werner's view, this "timid" approach has resulted in excess deference to SROs in matters of market structure. See id. at 1255.

Werner acknowledged reasons for this pattern, highlighting, for example, Congress's delegation of the market structure issues of the National Market System to the SEC, in large part because Congress itself found them too sensitive and difficult to resolve. Taking its cue from Congress, the SEC did likewise, passing on those same issues to the SROs. See Werner, supra note 221, at 756. Further, Werner noted, effective market structure regulation requires an economic understanding of, and economic data on, the operation and function of the securities markets. But the SEC has never possessed such expertise. See Werner, supra note 223, at 1254. As a result, Werner concluded, today two Commissions exist: the "sunlight" SEC, which is concerned with disclosure and antifraud regulation and has been widely acclaimed, and a regulatory SEC, which has failed to fulfill its obligations and fallen into desuetude. See Werner, supra note 221, at 755-56.

Echoing these arguments, particularly in reference to section 10(b) of the SEA of 1934, Steve Thel has also challenged the prevailing emphasis in securities regulation on disclosure, versus the market structure issue of price regulation. See Thel, supra note 222, at 390. Thel points out that the Act, including section 10(b), does not discuss disclosure to any great extent, see id. at $390 \& \mathrm{n} .28$, but instead emphasizes price and its manipulation. See id. at 391-92. Rather than grant the SEC limited powers to mandate disclosure or otherwise, the SEA grants the SEC broad power-almost entirely unexercised-to all but take over the securities markets. "The Act provides for extensive control over 
regulate market structure is unacknowledged, and market structure remains unregulated. Market structure is thus left to the market itself. Likewise, its evolution, in the face of inevitable change, lies primarily in private hands.

The proposed network analysis of securities market transition, however, suggests at least some situations in which the market cannot, or will not, effectively manage transition. At least in such circumstances, securities regulators' understanding and regulation of market structure would seem essential. ${ }^{239}$ Such market structure regulation would ideally be of a systematic character, in contrast with the episodic responses to these issues that has historically been the norm. ${ }^{240}$ As suggested by Walter Werner's dichotomy of sunlight and regulation in the work of the SEC, some revival of limited but necessary regulation of market structure, with regulatory cueing at its heart, may be appropriate. ${ }^{241}$

\section{B. REGULATORY CUEING AND THE NATIONAL MARKET SYSTEM}

An appreciation of the potential inability of market institutions to efficiently manage their own transition may have contributed to the single major exception to the SEC's pattern of noninvolvement in issues of market structure, as described immediately above. The SEC's National Market System project of the early 1970s thus sought to address the failure of U.S. securities markets to adopt new technologies and achieve efficient market linkage. From a regulatory cueing perspective, the National Market System therefore warrants an analysis and an examination of its implications for the role and value of cueing in securities market transition.

\section{History of the National Market System}

The history of the National Market System has been widely surveyed, so a brief overview of its central elements will suffice. Beginning in the 1950 s, U.S. securities markets exhibited a steady pattern of growth, producing the first sustained bull market since the Roaring Twenties. ${ }^{242}$

several critical factors affecting prices, including production and dissemination of information that might affect prices, the flow of money into and out of the market, and the basic structure of the securities market." See id. at 391. In this line of critique, see also ROBERTA KARMEL, REGULATION BY PROSECUTION 105-07, 138 (1982); Nyquist, supra note 223, at 291-92.

239. See Werner, supra note 221 , at $782-83$.

240. See Nyquist, supra note 223, at 291-92.

241. Cf. Les Riordan, Three Proposals for a Latin American Stock Exchange in Miami: FullService Exchange, Private Offshore Market, or a Computerized Financial Information Service, 27 U. MiAMI INTER-AM. L. REV. 585, 630-31 (1996) (noting that with the rise of greater technology, the regulation of information and disclosure, and of trading, can no longer be separated, as the two functions cannot be separated).

242. Werner, supra note 221 , at 765 . 
Over-the-counter ("OTC") markets, which had been marginal players in the 1930 s, began to acquire substantial and growing market share. ${ }^{243}$ By the late 1950s, large financial institutions were actively trading large blocks of equity securities. ${ }^{244}$ Over the next decade, this trend would produce a quadrupling of equity share volume. ${ }^{245}$

Such increases in trading volume and speed began to place increasing strain on the securities markets, which had previously been accustomed to a relatively continuous flow of essentially homogenous transactions. ${ }^{246}$ Nonetheless, the securities industry resisted the adoption of new electronic data processing and communications facilities, which might have lightened its burdens. ${ }^{247}$ Nor did the SEC act to encourage the use of new communications, trading, and processing technologies. ${ }^{248}$ Consequently, by the late 1960 s, the markets were still relying on paper to settle what had become a near tidal wave of trades. ${ }^{249}$

In 1968, this unsustainable pattern reached its break point. ${ }^{250}$ Market participants' continued use of outdated methods of processing trades, their lack of a centralized clearing system designed to handle sudden surges in trading volume, and the absence of any mechanism to effectively distribute that trading volume began to trigger widespread accounting and reporting failures. ${ }^{251}$ Failures to complete trades became commonplace. ${ }^{252}$ Incidents

243. See id. at 766 .

244. See Seligman, supra note 217 , at 280; Werner, supra note 221 , at 767.

245. See 35 SEC ANN. REP. 1 (1969).

246. See Werner, supra note 221 , at 765 . See also SELIGMAN, supra note 217 , at $450-51$.

247. See Werner, supra note 221, at 767.

248. See id. at 765. See also SELIGMAN, supra note 217, at 441-42 (referring to SEC Chairperson Budge's laissez-faire-style policy).

249. See SELIGMAN, supra note 217, at 488-89; Werner, supra note 221 , at 770.

250. See SELIGMAN, supra note 217 , at 412 .

251. See Michael E. Don \& Josephine Wang, Stockbroker Liquidations Under the Securities Investor Protection Act and Their Impact on Securities Transfers, 12 CARDOZO L. REV. 509, 510-11 (1990). See also SELIGMAN, supra note 217, at 456-57; J. Robert Brown, Jr., The Shareholder Communication Rules and the Securities and Exchange Commission: An Exercise in Regulatory Utility or Futility?, 13 J. CORP. L. 683, 720 (1988) ("Following unprecedented trading volume, brokers and banks proved incapable of processing the increased number of transactions. Deliveries of stock and cash were delayed, stock certificates sometimes were lost."); Henry F. Minnerop, Clearing Arrangements, 58 Bus. LAw. 917, 932 n.67 (2003) ("With the NYSE handling 10 to 12 million shares daily, brokers were literally buried in paperwork and concern about risk was growing. The crisis was so severe that, in order to help reduce the backlog, the exchanges closed every Wednesday and shortened trading hours on the other days.").

252. See Don \& Wang, supra note 251, at 511. See also Seligman, supra note 217, at 451; Sam Nunn, The Impact of the Senate Permanent Subcommittee on Investigations on Federal Policy, 21 GA.

L. REV. 17, 34 (1986). According to Nunn,

Deliveries to customers of both cash and securities were often late, and stock certificates were frequently lost in the rising tide of paper. Securities firms lost control of their records and 
of fraud, including the theft of securities from broker-dealers, began to rise. $^{253}$

While brokerage firms had responded to the market upswing by expanding sales personnel, few had expanded their back-office capacity. ${ }^{254}$ Thus, when this paperwork crunch hit, most were quickly overwhelmed. A shortage of qualified personnel to perform back-office functions led to poaching of workers. ${ }^{255}$ As a result of rapidly growing costs, recordkeeping problems, and trade losses, capital shortages simultaneously struck almost every Wall Street firm. This set off a series of closures and, for the lucky few, mergers. ${ }^{256}$ By 1971, the NYSE had lost more than 100 member organizations. ${ }^{257}$ As Joel Seligman has described it:

The 1967-70 broker-dealer firm back-office crisis was the most serious failure of securities industry self-regulation in the Commission's history, a collapse of industry regulatory controls so complete that it permitted in the agency's retrospective view, "the most prolonged and severe crisis in the securities industry in forty years." 258

Congress initially responded to the back-office crisis with the Securities Investor Protection Act of 1970 ("SIPA"), ${ }^{259}$ which was

more than one hundred brokerages were forced into liquidation as a result of faulty recordkeeping and backlogs of uncompleted transactions.

Nunn, supra, at 34.

253. See Don \& Wang, supra note 251 , at 511.

254. See SELIGMAN, supra note 217 , at 455.

255. See Don \& Wang, supra note 251, at 511. See also SELIGMAN, supra note 217, at 455.

256. See SELIGMAN, supra note 217 , at $452-54$.

257. See Don \& Wang, supra note 251, at 511. See also SELIGMAN, supra note 217, at 452-53; Brown, supra note 251, at 720 ; Werner, supra note 221, at 770 ("An apparently healthy industry became deathly sick overnight as over a hundred broker-dealers, including many old and large firms, failed. Investors protected against fraud learned that they were not protected against broker-dealer insolvency; confidence in government regulation of the securities market was shaken.").

258. SELIGMAN, supra note 217 , at 450 (quoting STUDY OF UNSAFE AND UNSOUND PRACTICES, supra note 217) (internal footnote omitted). Some would accuse Seligman and the SEC of understating the severity of the crisis and its implications for the adequacy and efficiency of the securities markets. "One economic historian termed the 'paperwork crisis' as 'perhaps the single most dramatic technical failure of the free enterprise system on record anywhere."' Nunn, supra note 252, at 34 (quoting S. REP. No. $94-75$ (1975), reprinted in 1975 U.S.C.C.A.N. 183). Finally, in the SEC's more complete characterization:

A veritable explosion in trading volume clogged an inadequate machinery for the control and delivery of securities. Failures to deliver securities and to make payment ricocheted through the industry and firms lost control of their records and of the securities in their possession or charged to them. Operations conditions deteriorated so severely that securities markets were required to cease trading one day each week at one point, and later to limit daily trading hours.

Brown, supra note 251 , at 720 .

259. Pub. L. No. $91-598,84$ Stat. 1636 (1970) (codified as amended at 15 U.S.C. $\S 78$ aaa-7811 (2000)). See Werner, supra note 221 , at 770. 
designed to safeguard investors from losses due to their brokers' financial difficulties. In enacting SIPA, Congress was not primarily concerned with bailing out financially troubled broker-dealers, ${ }^{260}$ rather, it hoped to preserve economic stability by lessening the secondary effects of financial failure. ${ }^{261}$

Along with the adoption of SIPA, a quieter but ultimately more dramatic initiative of the SEC was also set underway. This began with the transmittal letter of the SEC's Institutional Investor Study Report of March $1971{ }^{262}$ In that letter, the SEC spoke for the first time of the need for a national securities market system: ${ }^{263}$ "[M]odern communication and data processing facilities [make] it possible to preserve geographically separated trading markets while at the same time tying them together on a national basis. $" 264$

Disclaiming any intent to mandate or describe in detail the future structure of the securities markets, the SEC nonetheless stated its objective "to see a strong central market system created to which all investors have access, in which all qualified broker-dealers and existing market institutions may participate in accordance with their respective capabilities, and which is controlled not only by appropriate regulation but also by the forces of competition."265 Later that same year, in a study responding to the back-office crisis, the SEC reemphasized this vision, endorsing "a modernized, nationwide system" of securities trading ${ }^{266}$ and speculating about a future market heavily dependant on electronic transactions. ${ }^{267}$

The following year, the SEC again sounded this theme, further developing its unprecedented concept of a National Market System in a

260. See Don \& Wang, supra note 251 , at 512-13.

261. See id. at 513 (citing H.R. REP. NO. 91-1613, at 3 (1970), reprinted in 1970 U.S.C.C.A.N. $5254,5255)$.

262. INSTITUTIONAL INVESTOR STUDY REPORT OF THE SECURITIES AND EXCHANGE COMMISSION, H.R. DOC. No. 92-64, pt. I, at xxiv (197I) [hereinafter INSTITUTIONAL INVESTOR STUDY] (letter of transmittal).

263. See Seligman, supra note 229, at 80 . See also Michael J. Simon \& Robert L.D. Colby, The National Market System for Over-the-Counter Stocks, 55 GEO. WASH. L. REV. 17, 44-45 (1986).

264. INSTITUTIONAL INVESTOR STUDY, supra note 262, at xxiii.

265. See Seligman, supra note 229 , at 80 (quoting INSTITUTIONAL INVESTOR STUDY, supra note 262 , at xxv). To similar effect, the SEC stated: "A major goal and ideal of the securities markets and the securities industry has been the creation of a strong central market system for securities of national importance, in which all buying and selling interest in these securities could participate and be represented under a competitive regime." Jeffry L. Davis \& Lois E. Lightfoot, Fragmentation Versus Consolidation of Securities Trading: Evidence from the Operation of Rule $19 \mathrm{c}-3,41 \mathrm{~J}$. LAW \& ECON. 209, 210 (1998) (quoting INSTITUTIONAL INVESTOR STUDY, supra note 262, at xxiv).

266. See STUDY OF UNSAFE AND UNSOUND PRACTICES, supra note 217 , at 1 .

267. See id. at 8 . 
separate Statement on the Future Structure of the Securities Markets. ${ }^{268}$ Therein, the Commission announced its intention to

enhance the competition which now takes place among the separate exchange markets and between all of them and the third market (nonexchange member over-the-counter dealers in exchange listed securities) [while] centralizing all buying and selling interest and maximizing market-maker capability ... so that securities can be bought and sold at reasonably continuous and stable prices, and to ensure that each investor will receive the best possible execution of his order, regardless of where it originates. ${ }^{269}$

Although later annual reports and other SEC publications commented further on the proposed National Market System, ${ }^{270}$ the SEC's last major pronouncement on the National Market System issue came in its 1973 Policy Statement on the Structure of a Central Market System. ${ }^{271}$ In this Statement, the SEC emphasized that "the most important objective of the system is to foster the development of strong competition among its participants." 272 Further, the Commission specifically noted that "restrictions such as Rule 394 [the earlier numbering of NYSE Rule 390, which restricted off-exchange trading of listed securities by NYSE members], regardless of their past appropriateness, are incompatible with a central market system and will have to be rescinded."273

Ultimately, this insistent explication culminated in Congress's adoption of the 1975 Securities Acts Amendments ("SAA"). ${ }^{274}$ Section $11 \mathrm{~A}$ of the SAA called for the establishment of a National Market System. ${ }^{275}$ Specifically, the SEC was directed to accomplish this task in accordance with five principles Congress deemed necessary for "the

268. Interpretive Releases Relating to the Securities Exchange Act of 1934 and General Rules and Regulations Thereunder: Statement on the Future Structure of the Securities Markets, 37 Fed. Reg. 5286 (Mar. 14, 1972) [hereinafter Future Structure]. See 38 SEC ANN. REP. 7 (1972).

269. See Seligman, supra note 229 , at 81.

270. The 1973 and 1974 SEC Annual Reports, for example, maintained support for a National Market System by outlining various reasons for, and ways to develop, such a system. See 40 SEC ANN: REP. 3-4 (1974); 39 SEC ANN. REP. 3, 5-7 (1973).

271. See Policy Statement of the SEC on the Structure of a Central Market System, Sec. Reg. \& L. Rep. (BNA) No. 196, at D-1 (Apr. 4, 1973) [hereinafter Policy Statement].

272. See Seligman, supra note 229, at 81 (citing Policy Statement, supra note 271, at 8).

273. See id. (citing Policy Statement, supra note 271, at 48).

274. Pub. L. No. 94-29, 89 Stat. 97 (codified as amended at 15 U.S.C. $\$ 78$ k-I(a)(2) (1996)). See Macey \& Haddock, supra note 4, at 321.

275. See Eric C. Otness, Balancing the Interests of Retail and Institutional Investors: The Continued Quest for Transparency in Today's Fragmented Equity Markets, 96 Nw. U. L. REV. 1607, 1618 (2002) (citing Richard W. Jennings, HaROld MARSh, JR., JOHN C. COFFEe, JR. \& JOEL Seligman, SeCurities Regulation 30 (8th ed. 1998)). 
protection of investors, and the maintenance of fair and orderly markets." ${ }^{276}$ Congress thus directed the SEC to ensure the following:

(i) economically efficient execution of securities transactions; (ii) fair competition among brokers and dealers, among exchange markets, and between exchange markets and markets other than exchange markets; (iii) the availahility to hrokers, dealers, and investors of information with respect to quotations for and transactions in securities; (iv) the practicability of brokers executing investors' orders in the best market; and (v) an opportunity, consistent with the provisions of clauses (i) and (iv) of this subparagraph, for investors' orders to be executed without the participation of a dealer. ${ }^{277}$

Congress did not define National Market System in the SAA. ${ }^{278}$ The term, however, was understood as "a comprehensive reference to those regulatory and technological steps which the SEC and the securities industry must take in order to integrate the mechanisms for trading qualified securities and the trading behavior of investors and securities professionals in order to achieve a nation-wide interactive market system."279 As such, the National Market System's central objective appeared to be efficient linkage of the numerous U.S. exchange floors and the OTC dealer markets. ${ }^{280}$

Strangely, however, with the adoption of the SAA in 1975, the entire National Market System effort seemed to come to an end. ${ }^{281}$ After 1975, the SEC's efforts toward a National Market System seemed to slow in pace and become decidedly less directed at actively promoting the creation of such a system and, at best, more focused on addressing occasional anomalies in private efforts at market restructuring. This is not to suggest that nothing was done. For example, the SEC adopted Rule 19c-3, which prohibited off-board trading restrictions on securities listed on or after April 26, 1979, ${ }^{282}$ and Rule $11 \mathrm{Aa} 2-1$, which introduced the concept of a National Market System security. ${ }^{283}$ These efforts, however, were not

276. Securities Exchange Act of 1934, 15 U.S.C. \& 78k-1(a)(2) (2000). See Macey \& Haddock, supra note 4 , at 321 .

277. 15 U.S.C. \& 78k-1(a)(1)(C)(i)-(v). See Macey \& Haddock, supra note 4, at 322.

278. See Macey \& Haddock, supra note 4 , at 321 .

279. Otness, supra note 275, at 1619 (citing 42 Fed. Reg. 33,510 (June 23, 1977)).

280. See id.

281. See Werner, supra note 221, at 776-77.

282. See Off-Board Trading Restrictions, 45 Fed. Reg. 41,125 (June 18, 1980). See also Seligman, supra note 229 , at 116, 124.

283. See Borrelli, supra note 237, at 836 (citing Designation of National Market System Securities, Exchange Act Release No. 17,549, 22 S.E.C. Docket 22 (Feb. 17, 1981), available at 1981 WL 37744 , at *I). 
directed to the actual creation of a National Market System, but spoke only indirectly to that goal.

\section{Regulatory Cues in the National Market System Project}

A regulatory cueing analysis of the development of the National Market System begins with an appreciation of the fact that a National Market System, or at least significant elements of it, actually exists in the United States today. ${ }^{284}$ This becomes evident when we focus on the SEC's goals for the National Market System as distinct from its proposed means to achieve those goals.

Focusing on the peculiar acme of the SEC's National Market System efforts-the SEC's annual reports, policy statements, and other releases from 1971 to 1975-several important goals for the National Market System can be identified. As early as 1972, the SEC had broadly identified "centraliz[ation] [of] all buying and selling interest and maximiz[ation] [of] market-making capacity" as the "twin objectives" of a National Market System. ${ }^{285}$ More specifically, the SEC felt that the National Market System should be a "system in which competing market-makers will generate the best prices, in which comprehensive disclosure will . . . obtain the best executions, [and] to which all qualified broker-dealers will have access." 286 It further spoke of the dissemination of information on prices, volume, and quotes as an "essential step" in the creation of a National Market System, ${ }^{287}$ and emphasized the broker's primary duty to "use reasonable diligence to obtain best execution of each order entrusted to him." 288 Other enumerated goals included a desire to ensure the ability of national markets to provide adequate hquidity and to foster the

284. See HAZEN, supra note 226, at 536-37; Donald L. Calvin, The National Market System: A Successful Adventure in Industry Self-Improvement, 70 VA. L. REV. 785, 787-88 (1984); Karmel, supra note 220, at 3 (noting the achievement of some of the goals of the National Market System); Simon \& Colby, supra note 263 , at $72-73$. It bears noting that only partial achievement of those goals does not undermine the regulatory cueing thesis that follows; rather, it recognizes that the SEC's cueing effort was itself imperfect, and that even if it was not, other forces might have undermined its efficacy.

285. See Future Structure, supra note 268, at 5287.

286. See id. at 5286. The SEC further narrowed the focus of a National Market System by defining four objectives: (1) a comprehensive disclosure system, (2) elimination of inefficient exchange rules, (3) "establishment of terms and conditions upon which any qualified broker-dealer can attain access to all exchanges," and (4) "[i]ntegration of third market firms ... by including them in the disclosure system... and making them subject to appropriate market responsibilities and other regulatory requirements commensurate with the benefits they may realize." See id. at 5287.

287. See David Lipton, Best Execution: The National Market System's Missing Ingredient, 57 NOTRE DAME L. REV. 449, 451 (1982) (quoting Future Structure, supra note 268, at 5287).

288. Id. (quoting H.R. REP. No. 93-52, at 912 (1974)). 
development of strong competition in the securities markets. ${ }^{289}$ Yet more specifically, the goals of the National Market System included unfixing commission rates, eliminating barriers to competition, and instituting lastsale data and quotation reporting. ${ }^{290}$

The SEC also proposed an array of concrete means to these ends. For example, the SEC recommended that all third-market firms be incorporated into the central market system through their mandatory inclusion in the information-dissemination system and their compliance with appropriate registration requirements and other market responsibilities. ${ }^{291}$ Another proposal would have imposed a specific best execution duty on brokerdealers. ${ }^{292}$ Finally, yet another would have required retail firms to compete directly with exchange specialists, and exchange specialists to make a market in OTC securities. ${ }^{293}$

Focusing on the SEC's goals, rather than proposals, for a National Market System, it becomes clear that much has been accomplished. Roberta Karmel thus points to comprehensive market linkages and orderrouting systems as goals of the National Market System that were achieved through the ITS and other electronic systems. ${ }^{294}$ Barriers to competition among trading systems have also been reduced, as evidenced by the far wider dissemination of market share in recent years. Likewise, bid-ask spreads have diminished, suggesting some greater proximity to best execution. $^{295}$ Information distribution, finally, is also increasingly widespread.

Why, then, have the SEC's efforts been widely branded a failure? In large part, this assessment arises from the SEC's less impressive record in

289. See Policy Statement, supra note 271, at D-2.

290. See Simon \& Colby, supra note 263, at 45-46. For further discussion of the goals of the National Market System effort, see Karmel, supra note 220, at 3; Werner, supra note 221, at 774.

291. See Future Structure, supra note 268, at 5287.

292. See Lipton, supra note 287 , at 451.

293. See Seligman, supra note 229 , at 116.

294. See Roberta S. Karmel, Turning Seats into Shares: Causes and Implications of Demutualization of Stock and Futures Exchanges, 53 HASTINGS L.J. 367, 389 (2002) (stating that initiatives of the National Market System included order-routing systems and comprehensive market linkage, and noting that such linkage was achieved through the ITS). See also Simon \& Colby, supra note 263, at 72-73 (describing the success of OTC last-sale reporting).

295. See Laura Nyantung Beny, U.S. Secondary Stock Markets: A Survey of Current Regulatory and Structural lssues and a Reform Proposal to Enhance Competition, 2002 CoLUM. Bus. L. REV. 399, $407-09$. 
securing implementation of its specific market microstructure proposals. ${ }^{296}$ A universal message switch, for example, though discussed at some length by the SEC, was never implemented. ${ }^{297}$ Likewise, the alternative mechanism of a composite limit order book was never established. ${ }^{298}$

From a cueing perspective, however, this makes perfect sense. Understood as regulatory cues, the SEC's specific proposals are cases of its promotion of particular coordination equilibria. Achievement of these particular equilibria need not have been the goal, however. ${ }^{299}$ Such cues may instead have served to facilitate coordination generally. Alternatively, the SEC's cues may have sought to facilitate some particular coordination goal-a mechanism for quote dissemination, for example-without concern for the details of its design. ${ }^{300}$

This need not suggest that the National Market System was a complete, or even substantial, success. Rather, a cueing perspective posits only that the indicia of success may be distinct where public agencies, such as the SEC, seek to facilitate market transition using regulatory cues. The National Market System, in this view, may not have been a success, but may have been far more successful than commonly conceived.

Taking this cueing analysis of the National Market System effort a step further, one can consider how the SEC's National Market System goals were actually achieved. As already noted, the SEC did relatively little beyond discuss a National Market System. Most of the progress toward the goals of the system arose from the market itself. ${ }^{301}$ Even the SEC has acknowledged as much. ${ }^{302}$ Private action by market participants, including substantial coordination by them, can thus be said to have created the National Market System. The ITS that emerged to link U.S. securities markets, for example, was encouraged by the SEC but was created by a

296. See generally Norman S. Poser, Restructuring the Stock Markets: A Critical Look at the SEC's National Market System, 56 N.Y.U. L. REv. 883 (1981) (recommending that Congress reconsider the desirability of a National Market System due to the SEC's inability to develop it).

297. See Seligman, supra note 4, at 669.

298. See id.

299. See supra Part IV.B.1.

300. See supra Part IV.B.1.

301. See Calvin, supra note 284, at 810. See also Mendelson \& Peake, supra note 3, at 447.

302. See Order Execution Obligations, 60 Fed. Reg. 52,792, 52,792-01 (Oct. 10, 1995) ("The undertaking primarily was placed on the shoulders of the securities industry: the Commission took seriously the Congressional mandate that it 'facilitate' these goals while allowing maximum flexibility in the design."). 
coalition of private entities. ${ }^{303}$ More specifically, private entities undertook the ITS initiative in the face of an SEC proposal to create a far more elaborate communications and order-routing scheme. ${ }^{304}$

Nor is the ITS unique in this regard. ${ }^{305}$ One might also note the creation of a consolidated tape, first proposed in the SEC's Institutional Investor Report transmittal letter. This proposal was soon picked up by a NYSE-convened task force and ultimately brought to fruition by private creation of the Consolidated Tape Association, which relied on the privately run Securities Industry Automation Corporation for its operation. ${ }^{306}$ A central private role in achieving the goals of the National Market System has consequently been widely recognized..$^{307}$

The SEC's proposal and description of these institutions of market linkage, however, can be conceived as regulatory cues. In each case, the SEC encouraged the creation of the relevant mechanism and posited parameters for its operation. Rather than lead to the implementation of regulations creating such market linkages, however, these cues simply served to facilitate the coordination necessary for private market actors to create the relevant linkage themselves.

303. See Charles C. Cox \& Douglas C. Michael, The Market for Markets: Development of International Securities and Commodities Trading, 36 CATH. U. L. REV. 833, 846-47 (1987). See also Nyquist, supra note 223, at 294 n.62.

304. See Simon \& Colby, supra note 263, at 49-50.

305. Another example of such private initiative in the face of the SEC's regulatory signal was the creation of the National Securities Clearing Corporation from the separate stock clearing operations of the NYSE, the American Stock Exchange, and the NASD. See Calvin, supra note 284, at 800 ("NSCC was conceived as the central element in an integrated nationwide effort to eliminate unnecessary duplication of post-trade activities and to permit single-account clearing and settlement for brokerdealers in the clearing organization of their choice.").

306. See Seligman, supra note 229 , at $87-88$. See also Calvin, supra note 284 , at 800 (noting that the development of the consolidated tape and the Consolidation Quotation System was underway before Congress's adoption of the SAA); Nyquist, supra note 223, at 294 n.60. Cf. Seligman, supra note 4, at 643 ("By the time of the ISEC Advisory Committee on Market Information], the stock and options markets (self-regulatory organizations or SROs) under this framework had acted jointly to develop plans for the consolidated collection and dissemination of market information."). The dramatic, if still incomplete, advances in trading technology in the aftermath of the National Market System effort might also be cited as an example of how the public signaling of the SEC helped encourage structural change by market participants themselves.

307. See Seligman, supra note 4, at 659 n.97. See also Steve Wunsch, Market 2000: The Future of Proprietary Trading Systems and the National Market System, 1NSIGHTs, Apr. 1993, at 16, 19. The development of the Consolidated Quotation System, although somewhat in line with the proposed cueing pattern, was more strongly resisted by the NYSE, and so less readily fits that pattern. This example, however, may suggest a case of the NYSE playing bully, as may sometimes occur in coordination games. See Aviram, supra note 46, at 15-16. 
The resulting market institutions did not track the SEC's articulated parameters; rather, they were designed to meet the efficiency demands of their private sponsors. Yet this is exactly as it should be, and as cueing theory would predict. There is little basis for confidence in any SEC prediction of optimally efficient market structures, particularly in a time of rapid technological change and transition more generally. Therefore, SEC regulation need only overcome coordination-related barriers to efficient transition. Regulatory cues, by design, do that and no more.

Yet this begs a further question. If what U.S. securities markets have by way of a National Market System can most directly be credited to private action, how can we conclude that SEC action, in the form of cues or otherwise, played any role in the process? Instead, the changes described may have occurred at the precise moment they became technologically and economically feasible, and no earlier.

Although any identification of SEC regulation as the proximate, or even contributory, cause of the national market changes of the 1970s and 1980 s is necessarily tentative, several factors are at least suggestive of a correlation. To begin with, the near simultaneous pursuit of various market linkages by securities market participants beginning in the early 1970s would seem peculiar, absent the existence of some common trigger. That SEC regulation was that trigger is suggested by the particular timing of those efforts, which followed quite directly from the relevant SEC statements, proposed regulations, and other cues. It would seem at least suggestive that after a long period of resistance to modernized technologies and related improvements, even in the face of progressive growth in the volume and speed of trading, private actors on the securities markets suddenly sprang to action in the immediate aftermath of the SEC's National Market System efforts. Finally, the correlation of the SEC's pronouncements and private market restructuring is further strengthened by the several parallels in the SEC's articulated proposals and the institutions thereafter implemented by securities market actors.

In essence, in the case of the National Market System, the SEC can be said to have "facilitated" the market transition process. ${ }^{308}$ As put by one SEC staff member, "[w] hen required to act, the Commission has eliminated practices that detract from National Market System objectives, or set

308. See Order Execution Obligations, 60 Fed. Reg. 52,792, 52,792 (Oct. 10, 1995); STAFF OF HOUSE SUBCOMM. ON OVERSIGHT AND INVESTIGATIONS AND SUBCOMM. ON CONSUMER PROTECTION AND FINANCE, HOUSE COMM. ON INTERSTATE AND FOREIGN COMMERCE, 95TH CONG., REPORT ON OVERSIGHT OF THE FUNCTIONING AND ADMINISTRATION OF THE SECURITIES ACTS AMENDMENTS OF 1975, at 4 (Comm. Print 1977). 
necessary market wide standards, while preserving maximum flexibility for the markets to design, implement, and govern any needed facilities or systems." ${ }^{309}$ The SEC provided such facilitation, it would appear, through the mechanism of regulatory cues. These cues included the provision of information in the SEC's multiple policy pronouncements, the encouragement of private action through its own episodic initiatives, and the clear threat of agency action suggested by its pursuit of an explicit legislative mandate authorizing it to act, notwithstanding its existing authority to do so. ${ }^{310}$

Ultimately, the SEC's seemingly empty rhetoric of a National Market System may have been just the opposite. It may have been just the regulatory need prescribed by the process of network transition in which U.S. securities markets found themselves.

\section{SECURTIES MARKET SELF-REgUlation}

A cueing theory of law in securities markets is supported by the extensive reliance on self-regulation in securities law. U.S. securities legislation incorporates what may be the most elaborate self-regulatory regime in U.S. law today. The overall scheme of the U.S. securities laws is thus one of "supervised self-regulation." ${ }^{11}$ Within this system, industrybased SROs have statutorily recognized powers to regulate their members. In fulfilling these functions, however, they are overseen by the SEC. ${ }^{312}$

309. Annette L. Nazareth, Securities Law for the Next Millennium: A Forward-Looking Statement, 75 ST. JOHN's L. REV. 15, 28 (2001).

310. Besides the fact that the SEC did not act on the power that Congress gave it in 1975, the fact that the SEC already had the powers that the SAA nominally gave it further supports a cueing interpretation of the National Market System. See Werner, supra note 221, at 778.

311. The system in place in securities markets has also been termed one of "audited selfregulation." See Douglas C. Michael, Federal Agency Use of Audited Self-Regulation as a Regulatory Technique, 47 ADMIN. L. REV. 171, 176-77 (1995) (defining "[a]udited self-regulation... as the delegation by Congress or a federal agency to a nongovernmental entity the power to implement laws or agency regulations, with powers of review and independent action retained by the federal agency").

312. Various forms of self-regulation fall somewhere on a spectrum ranging from the government's formal delegation of regulatory authority (arguably the securities market case) to the private sector's perception of a need to regulate itself (and action based on that perception). See Angela J. Campbell, Self-Regulation and the Media, 51 FED. COMM. L.J. 711,714 (1999). More specifically, one author has suggested the existence of five models of self-regulation. See Margot Priest, The Privatization of Regulation: Five Models of Self-Regulation, 29 OTTAWA L. REV. 233 (1997). The first model, voluntary codes of conduct, operates with little government involvement and, accordingly, little force of law. See id. at 245-51. The next model, statutory self-regulation, operates with somewhat more governmental involvement. This model has a little more teeth, providing for judicial review and some public accountability. See id. at 251-56. The third model, firm-defined regulation, is characterized by government monitoring of private rule enforcement and the possibility of court review of decisions. See id. at 256-59. The fourth model, supervised self-regulation, is the model in the 
It has been suggested that self-regulation in securities law is grounded in the late arrival of federal securities law. ${ }^{313}$ By the time the Securities Exchange Act ("SEA") was adopted in 1934, at least twenty-one stock exchanges already existed in the United States. ${ }^{314}$ The largest of these, the NYSE, had long been governed by a committee consisting of the president of the Exchange, its treasurer, and forty other members. ${ }^{315}$ Much of its governance was conducted by committees, which included committees on business conduct, stock listing, admission, arrangements, publicity, and law and arbitration. ${ }^{316}$

But this history alone cannot explain the persistence of self-regulation in the securities law regime. There were any number of characteristics of the pre-1933 securities markets that did not survive the federalization of securities law. Even self-regulation was challenged regarding its ability to control the improper trading practices that preceded the stock market crash of 1929.317 Thus, the original form of the SEA would have given a government agency detailed and pervasive authority to regulate the exchanges, the securities traded on those exchanges, and the issuers of those securities. ${ }^{318}$ This was rejected, however, pursuant to the counsel of the Dickinson Report. ${ }^{319}$ The SEA instead created the SEC and gave it the power to oversee the existing SROs and to intervene as necessary.

Self-regulation was thereby embedded in the securities regulation regime. ${ }^{320}$ With time, however, it has actually grown in importance and application. With the adoption of the SEA, a number of important segments of the securities industry that were not covered under the

securities market. See id. at 259-62. The final model, regulatory self-management, has relatively little self-regulation; a government agency controls many of the regulations, enforcement efforts, and sanctions. See id. at 262-67. See also id. at 242 tbl.1 (displaying the general characteristics of each model).

313. See Marianne K. Smythe, Government Supervised Self-Regulation in the Securities Industry and the Antitrust Laws: Suggestions for an Accommodation, 62 N.C. L. REV. 475, 480 (1984) ("By the time the country's collective political wisdom determined, in the years following the stock market crash of 1929 , that such self-regulation was not adequate to police the industry, a substantial self-regulatory structure had already developed, and was already in place in the securities industry.").

314. See id. (citing Stock Exchange Regulation: Hearings on H.R. 7852 \& 8720 Before the House Comm. on Interstate and Foreign Commerce, $73 \mathrm{~d}$ Cong. 746 (1934)).

315. See id. (citing S. REP. No. 73-1455, at 78 (1934)).

316. See id.

317. See, e.g., id. at 481 ; Poser, supra note 108, at 535.

318. See Smythe, supra note 313, at 481-82.

319. See id.

320. See Borrelli, supra note 237 , at $827-32$ ("In regulating the securities industry, the SEC relies heavily on a well-entrenched self-regulatory system, much of which was in place before the agency was formed."). 
umbrella of industry self-regulation remained. Specifically, broker-dealers in OTC securities were still directly regulated by the SEC. In 1938, however, Congress amended the SEA to create the NASD. ${ }^{321}$ Selfregulation, Congress believed, would effectively regulate business conduct without the evils of public regulation, provided the government stood as a watchperson, "exercising appropriate supervision in the public interest . . ." $\$ 322$

This expanding use of self-regulation in the securities markets has occasionally been challenged. Specifically, allegations of widespread fraud in the securities industry in the late $1950 \mathrm{~s},{ }^{323}$ and the dramatic financial losses to customers during the 1968-70 paperwork crisis-which also gave rise to the National Market System ${ }^{324}$ - provoked efforts to contract the scope of self-regulation, but neither made any substantial dent in its general advance. ${ }^{325}$ As a result, the securities markets continue to rely extensively on self-regulation.

That self-regulation has persisted in the securities markets and is beneficial may, at least in part, be correlated with the efficacy of regulatory cues in those markets. ${ }^{326}$ As described above, regulatory cueing is distinguished from ordinary regulation by the greater private role in its implementation. ${ }^{327}$ This is grounded in both the relative congruence of private interests in the coordination game of securities market transition ${ }^{328}$ and in the network-related alignment of public and private interests in that process. ${ }^{329}$ Thus, regulatory cueing rests on, and invites a complex interplay of, public and private action.

The same can be said of self-regulation in the securities markets. Broad parameters of public policy are crafted publicly in a form readily analogized to regulatory cues. Definition and implementation, as well as some degree of selection among competing policies, are then carried out by

321. See 69 AM. JUR. 2D Securities Regulation: Federal § 346 (1993) (citing 83 CONG. REC. 68 (1938) (address of William O. Douglas)).

322. See Smythe, supra note 313, at 485 (quoting S. REP. No. 75-1455, at 4 (1938)).

323. See id.

324. See id. at 486-87.

325. See id. at 487; Poser, supra note 108, at 532-33.

326. As to the substantial part of the self-regulatory regime and practice that is directed to shaping market structure, particularly in the face of evolving market conditions, regulatory cueing has direct application. Not all aspects of self-regulation fit within the structural and transitional orientation of cueing theory, however, but self-regulation is nonetheless illustrative of the general dimensions of that theory.

327. See supra Part III.B.2.

328. See Ahdieh, supra note 6, at 337.

329. See id. at 337-38. 
private entities. Law's role in the securities market self-regulatory regime might thus be characterized as coordinative in nature. Law (in the form of legislation establishing or authorizing the work of a particular SRO) serves to define a specific private locus of decision and action, resolving what otherwise might be an intractable coordination problem. In a network environment, a coordinative mechanism can then be expected to effectively implement the given regulatory policy.

Both regulatory cueing and self-regulation, meanwhile, are grounded in the heightened efficiency returns of private action. ${ }^{330}$ Both also look to the likely greater expedition of private solutions. ${ }^{331}$ Their scope of application is also similar, as is evident from the widespread interest in self-regulation in network-driven standard setting. ${ }^{332}$ The use of selfregulation in the securities industry context of simultaneous competition and cooperation, meanwhile, also parallels the framework within which regulatory cueing arises. ${ }^{333}$ Finally, self-regulation and regulatory cueing often require the same conditions for success, including high exit costs and some history of cooperation among market participants and between market participants and the government. ${ }^{334}$

Regulatory cueing might even be understood as a relatively mild form of the self-regulation presently used in securities markets. Thus, in the hierarchy of self-regulatory models, present securities market selfregulation involves a relatively engaged public role in the form of supervised self-regulation. ${ }^{335}$ Regulatory cueing, by contrast, would likely fall into one of the mildest categories of such regulation: "voluntary codes of conduct" or "statutory self-regulation." 336

330. See Matthew J. Feeley, EU Internet Regulation Policy: The Rise of Self-Regulation, 22 B.C. INT'L \& COMP. L. REV. 159, 172-73 (I999) (suggesting that the advantages of industry self-regulation of the Internet include "a greater degree of expertise and technical knowledge by the regulators, less bureaucracy resulting in quick adaptation of rules, flexible enforcement and internalized costs, all of which limit the need for governmental taxes").

331. See id. at $171-72$.

332. See id. at 172.

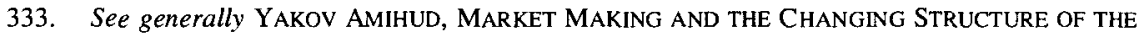
SECURITIES INDUSTRY (1985).

334. See Priest, supra note 312, at 301-02.

335. See id.

336. See id. at 242-44 (outlining the spectrum of self-regulatory models, with the proposed cueing theory showing selected traits of two of the least invasive forms of regulation). To similar effect, regulatory cueing falls into the most flexible of four categories of self-regulation posited by Bregman and Jacobson, which is defined by the twin axes of (1) setting the content of rules and (2) enforcement of those rules. See Eric Bregman \& Arthur Jacobson, Environmental Performance Review: SelfRegulation in Environmental Law, 16 CARDOZO L. REV. 465, 467-68 (1994). More generally, regulatory cueing might be argued not to fit into any of Bregman and Jacobson's categories; rather, it 
This may arise from the fact that some of the challenges of selfregulation do not arise in the case of regulatory cueing. In the network environments in which regulatory cues have primary application, regulated entities do not, for the most part, seek to avoid cueing regulation; rather, they wish to come within it. The dynamic of self-regulation is consequently likely to be at least somewhat different. ${ }^{337}$ Regulatory cueing involves its own difficulties, of course, but these would appear to be relatively more manageable.

Still, it is usefuI to think about regulatory cueing and self-regulation as closely tied mechanisms in the securities markets. This may suggest at least a partial explanation of why self-regulation has been so effective in that environment. It may also suggest useful lessons for the reach and capacity of self-regulation, including its necessary limitations. Selfregulation has not been used as widely outside the securities markets as one might expect. Some have suggested that this may arise from the modern existence of a regulatory state capable of direct regulation of even a vast economy. ${ }^{338}$ Cueing theory, however, suggests opportunities to introduce self-regulation more widely. ${ }^{339}$ For example, it suggests that network markets and industries might particularly benefit from greater use of selfregulation.

By the same token, a cueing perspective on self-regulation in securities markets suggests important limitations on the effectiveness of self-regulation. Obviously, its consistency and efficacy are likely to be diminished outside network and analogous contexts. Further, cueing theory suggests that self-regulatory regimes in securities markets should carefully define the bounds of public goal setting and private execution if they are to achieve an efficient equilibrium.

Although the use of self-regulation in securities markets is distinct from a reliance on regulatory cues, important parallels exist. The same attributes that enhance the efficacy of self-regulation increase the potential for regulatory cueing. Cueing theory's application in securities markets is thus supported by the success of these markets' self-regulation.

challenges their very premise, Cueing theory thus posits "regulation" that is about more than mere content setting and enforcement. As in Jody Freeman's analysis of the increasing identity of public and private regulatory functions, regulatory cueing is not simply about "shared governance," as there is nothing to "govern." Rather, it is a mechanism of problem solving and decisionmaking. See Freeman, Public Governance, supra note 181, at 548.

337. See Michael, supra note 311 , at 176-77.

338. See, e.g., Smythe, supra note 313 , at 478.

339. To similar effect, regulatory cueing may also suggest forms of self-regulation beyond existing conceptions of such regulation. See supra notes 335-36 and accompanying text. 


\section{APPLICATIONS AND IMPLICATIONS OF REGULATORY CUES IN SECURITIES MARKET TRANSITION}

With an eye to the regulatory cueing dimensions of securities law outlined above, we can conclude by considering the significance and lessons of cueing theory for several aspects of market structure with network dimensions: market consolidation versus fragmentation, the choice of auction versus dealer markets and of continuous versus periodic trading, and the ex ante preference for public securities markets versus banks as the primary source of corporate finance. In these areas, network obstacles to transition are possible, and regulatory cueing may therefore be applied fruitfully. In other words, these are market structure issues for which compatibility and connectivity matter; consequently, network effects run through them, and regulatory cueing may therefore be needed to initiate and encourage market reform and restructuring. Several of these are among the central issues facing the newly emerging securities markets not only of central and eastern Europe, but of western Europe as well. For these nations in particular, these issues provide important lessons regarding the role of cueing theory in efficient transition.

\section{A. CONSOldDATION Versus Fragmentation}

In the presence of network effects, there are affirmative efficiency benefits to the concentration of demand. In traditional terms, network compatibility enhances network participants' utility. ${ }^{340}$ This follows quite readily from the increasing returns to scale that characterize network economies. ${ }^{341}$ The greater the capacity for interconnection, the larger the number of participants on a given network, and hence, the greater the resulting efficiency gains to each participant. ${ }^{342}$

In networked securities markets, market linkage, whether in the form of indirect information dissemination or direct market linkage, should therefore be preferred. In calling for a National Market System, Congress sought to pursue just this goal, delegating the "task of creating an appropriate linkage mechanism to the SEC and the securities industry." ${ }^{\text {"343 }}$ In this way, Congress sought a greater degree of transparency, with real-

340. See Ahdieh, supra note 6, at 305 n.117.

341. See id. at 280 .

342. See id. at 305 n.117.

343. Calvin, supra note 284 , at 791. 
time trade and quote information widely disseminated among market participants. ${ }^{344}$ In this environment,

[p]urchasers and sellers [now] have access to current market information and are therefore in a better position to assess the market value of securities, to evaluate the fairness of fees or brokerage charges that they pay to intermediaries, and to assist regulators in controlling trading abuses such as insider trading. ${ }^{345}$

Conversely, with market fragmentation, consumers are denied these benefits and must necessarily find any given exchange, and equity investment generally, less valuable. ${ }^{346}$

The clearest example of network efficient linkage is likely the telephone system. ${ }^{347}$ More specifically, for our purposes, telephones highlight the marked benefit of consolidation to a single network. Thus, to maximize the network benefits in telecommunication, I want a single telephone that will connect me to all other telephone users, not a series of telephone networks (and hence, telephone units) that reach only a subset of other users. ${ }^{348}$

An analogous singularity applies in securities markets as well. ${ }^{349} \mathrm{~A}$ universal linkage is thus important to the network gains sought in securities market transition. ${ }^{350}$ By favoring and facilitating a consolidated securities market, or at least interlinked markets, emerging market economies in

344. J. William Hicks, Securities Regulation: Challenges in the Decades Ahead, 68 IND. L.J. 791, 800 (1993).

345. Id.

346. Cf. Mark Klock, The SEC's New Regulation ATS: Placing the Myth of Market Fragmentation Ahead of Economic Theory and Evidence, 51 FLA. L. REV. 753, 754 (1999) (challenging the SEC theory that market fragmentation reduces market efficiency).

347. See Ahdieh, supra note 6, at 288 n.38.

348. See id.

349. See Werner, supra note 223 , at 1244 . It bears emphasizing that consolidation to a single network is not inherently anticompetitive; rather, it involves a preference for second-order competition within a standard (e.g., price competition among multiple providers on a single network) over firstorder competition regarding the choice of standard (e.g., battles over the choice of alternative- or directcurrent electricity transmission and between Windows versus Apple operating systems). Ronald Gilson highlights this in the context of the credit card industry's market structure. In Gilson's analysis, Visa and MasterCard have organized themselves "as (effectively) non-profit cooperatives open to any bank, [such that] members could both cooperate in creating the network, while competing intensely at the issuer level in order to attract customers and merchants." Gilson, supra note 157, at 37-38.

350. Of course, such universal linkage into a common network is costly and difficult. The ITS provides a mechanism for price protection, but only by requiring that various markets use the same data. See Richard P. Bernard, International Linkages Between Securities Markets: "A Ring of Dinosaurs Joining Hands and Dancing Together?," 1987 Colum. Bus. L. REv. 321, 331 (1987). This data requirement, however, has been a source of substantial difficulty in "attempts at integrating the United States exchanges and OTC markets." See id. 
central and eastern Europe can maximize network size, as well as the universality of information, both financial and economic. ${ }^{351}$ Such markets' improved price discovery and resulting efficiency, together with their greater liquidity, can be expected to diminish the cost of capital and enhance economic growth.

This is not to suggest that there are no limits to efficient consolidation; rather, there are likely circumstances in which some degree of fragmentation is efficiently preserved. In securities markets, for example, if market transparency were invariably preferred, one should never find traders executing on the third market and regional markets. Yet one finds such execution. ${ }^{352}$ This would suggest that some benefits of fragmentation continue to exist.

Among various possible arguments for such sustained fragmentation, one might note the greater potential for innovation among fragmented markets. ${ }^{353}$ The existence of parallel markets may also encourage heightened competition, and hence, increased incentives for capital investment. ${ }^{354}$ With competition, finally, "[r]eal resources will be invested in price discovery, new technology, and better rules," which will encourage beneficial specialization and accommodation of varying client needs. ${ }^{355}$

Even the present network effects frame of analysis is consistent with such fragmentation. Thus, the presence of network effects need not dictate complete consolidation in any given case. Most significantly, where the proportion of network value to inherent value in a particular good or service (i.e., the blend of value dependent on, and independent of, network

351. Whether achieved through an electronic linkage system among dispersed trading sites, through the centralizing of trading at a single site, such as the NYSE, see id. at 330-31; Calvin, supra note 284 , at $790-91$ (describing the shortcomings of proposals to consolidate trading at a single site), or through some other mechanism of information dissemination, centralization/consolidation are ultimately means to the end of information transparency. See Schizer, supra note 43, at 1571 (describing alternative means by which fragmentation might be remedied). In this light, the network efficiency benefits of a singular market to states in transition are apparent. A distinct question regarding the degree of consolidation, in addition to the choice of a centralized trading site or multiple electronically linked ones, is the question of whether such electronic linkages should provide automatic execution, drawing them more in line with a centralized model. See Cox \& Michael, supra note 303, at 847. See also Amihud \& Mendelson, supra note 21, at 1435-36. To date, automatic execution has not been implemented.

352. See Seligman, supra note 229, at 85-86.

353. See Beny, supra note 295, at 421-22.

354. See Hans R. Stoll, The Causes and Consequences of the Rise in Third Market and Regional Trading, 19 J. CORP. L. 509, 514, 516 (1994).

355. See Klock, supra note 346, at 771. Fragmentation supporters also argue that regulations designed to achieve transparency are "unduly burdensome to the traditional exchanges, with negative competitive implications." Beny, supra note 295, at 403. 
size) is relatively low, the benefits of the inherent traits of a given good may outweigh the network benefits of its larger competitor, at least for certain users. ${ }^{356}$ Such is the claim, for example, of insistent users of Apple personal computers. ${ }^{357}$

The balance of consolidation and fragmentation in securities markets is therefore a careful equilibrium. "The debate over market transparency involves the question of optimal transparency rules in light of both efficiency and fairness as well as the fact that different investors and traders prefer different levels of transparency." ${ }^{358}$ Thus, it is unsurprising that the costs and benefits of securities market linkage have been debated since the enactment of the Securities Act of 1933 and the 1934 SEA. ${ }^{359}$ What, then, if anything, should securities market regulators do to bring about market consolidation? For example, should they insist on the dissemination of trade and price information to competing markets? ? $^{360}$ Generally, attempts to impose such distribution requirements have been undertaken only with hesitation.

The network understanding of securities markets outlined above raises questions about the ability of securities markets to achieve an efficient balance of consolidation and fragmentation, absent some degree of public intervention. ${ }^{361}$ A network analysis highlights various potential obstacles to efficient linkage. These include the possibility of an unwillingness to invest the resources needed to construct electronic linkages, resistance to joining any given intermarket network (absent confidence that it will prevail), and a failure to invest the necessary resources to adequately maintain market linkages. ${ }^{362}$ As these examples suggest, the coordination necessary to achieve the appropriate equilibrium of centralization and fragmentation in any given market is complex, involving both horizontal

356. See Lemley \& McGowan, supra note 27, at 592. Both legal and financial scholars and analysts debate whether market consolidation or market fragmentation is the superior method of organizing the securities exchanges, and whether the law should be involved (and, if it should, at what level). See generally Hicks, supra note 344 (recommending that the U.S. government modernize the financial services regulatory system by developing appropriate domestic and international standards); Klock, supra note 346 (using economic theory to prove that market fragmentation will not damage U.S. financial markets).

357. See Pamela Samuelson \& Suzanne Scotchmer, The Law and Economics of Reverse Engineering, 111 YALE L.J. 1575, 1617-18 (2002).

358. See Beny, supra note 295, at 403.

359. See id. at 450-57; Klock, supra note 346, at 755-56.

360. Cf. Samuelson \& Scotchmer, supra note 357, at 1617-18 (discussing how computer makers, by keeping their systems proprietary, could exploit "network effects" and become a de facto standard in the market).

361. See supra Part II.B.

362. See supra Part II.B. 
coordination between competing market centers and vertical coordination between actors at different levels of market microstructure. In the former case, various exchanges and other trading systems, including dealer-based systems such as NASDAQ, ECNs, and other ATSs, must identify a system and standards for the efficient dissemination of trading information. Vertical coordination in the process of market consolidation, meanwhile, would require various systems also to incorporate existing and potential issuers, as well as professional market participants (e.g., brokers and dealers), into their efforts at coordination. It is in just this type of complex context that cueing theory counsels emerging markets to rely on regulatory cues to help facilitate efficient market consolidation. ${ }^{363}$

Such regulatory cues might take a variety of forms in facilitating securities market linkage. The SEC's pressing of a given proposal for consolidation, for example, might simultaneously serve to indicate to market participants the distinct and likely unattractive prospect of public dictation of a standard and also to provide a preliminary bargaining point in private negotiations among those market participants. This would include both the range of market participants that do not constitute, but merely participate in, the relevant network (i.e., brokers, dealers, issuers, and all but a very limited category of trading systems), and those market participants that might meaningfully compete to serve as sponsors of the network generally. For the latter group, an SEC cue promoting a particular regime may encourage entry by highlighting the possibility of an even less efficient outcome than joining, and losing, a Chicken game standards competition. ${ }^{364}$ For the balance of market participants, a proposed SEC standard may help to facilitate negotiations designed to maximize network participation and size. Even more simply, such a cue may serve as a conventional focal point in the resolution of the relevant coordination game.

Other regulatory cues relevant to the balance of securities market centralization and fragmentation might also be noted. The dissemination of information regarding the costs and benefits of various linkage models, including information regarding their use in other nations, may also be useful. In the coordination game among market sponsors, for example, such an informational cue can help to flag the costs of noncoordination.

363. Depending on whether the coordination sought in a given regard runs horizontally or vertically, different forms of cues might be appropriate. Among horizontal competitors, publicly sponsored conferences and working groups may be sufficient, while more substantive cues may be necessary to coordinate the expectations of issuers and brokers.

364. See supra note 96 . 
Finally, antitrust immunity, potentially by way of state action convening a working group of market participants charged to develop a more effective linkage system, may constitute another important cue in this area.

Notably, there has been some history of such intervention in securities markets in the National Market System effort. ${ }^{365}$ Thus, notwithstanding the potential efficiency gains from linkage, U.S. securities markets remained relatively fragmented into the 1970s. Important steps in this direction, however, were triggered by the SEC's National Market System drive. ${ }^{366}$

One of the most important advances of that era was the creation of the ITS. As previously noted, the ITS is a market linkage system designed to ensure that investors who choose to trade NYSE-listed stocks in one market will receive the best price available in any market trading those stocks. ${ }^{367}$ In the creation of the ITS, market regulators provided the initial impetus, proposing a linkage by which brokers using different exchanges would automatically route any order to the market offering the best price for the security to be traded. ${ }^{368}$ As expected, exchanges and brokerage firms strongly objected to this proposal, expressing concerns that such a linkage would eliminate broker discretion. ${ }^{369}$ In the face of it, however, they promptly implemented the privately constructed ITS linkage, which provides immediate order routing, but not automatic execution. ${ }^{370}$

More recently, the SEC's Regulation ATS can be seen as a regulatory signal designed to encourage greater interaction among ECNs and traditional trading systems. Adopted in December 1998, Regulation ATS progressively seeks to incorporate ECNs and other ATSs into the National Market System ${ }^{371}$ by expanding the definitions of both exchanges and ATSs. $^{372}$ As a partial consequence, ATSs must now publicly display

365. See Choi, supra note 233 , at 320.

366. See Poser, supra note 108, at 532 ("Under the leadership of Chairman Harold Williams in the 1970 s, the SEC attempted to shape the markets of the future by requiring the various market centers to create unified facilities for communication of quotations and transaction prices, [and] market linkage ....").

367. See Bernard, supra note 350 , at 328-30.

368. See Cox \& Michael, supra note 303, at 847.

369. See id. In their view, the proposal mistakenly placed too much emphasis on price, which should not be the sole determinant of trade. See id.

370. See id. For another example of private initiative to enhance market linkage or transparency in the face of public cues, see Seligman, supra note 4, at 643 ("By the time of the [SEC Advisory Committee on Market Information], the stock and options markets (self-regulatory organizations or SROs) under this framework had acted jointly to develop plans for the consolidated collection and dissemination of market information.").

371. See Klock, supra note 346, at 754.

372. See id. at 764-68. 
orders and prices for securities in which they have more than a five percent share of the total volume. ${ }^{373}$ Building on the SEC's formal measures, a broader pattern of linkage and merger efforts among trading systems seems to be emerging.

As these examples suggest, emerging market efforts to achieve an efficient balance of market consolidation and fragmentation may require some preliminary public role-a regulatory cue. The 1TS was a product of private action triggered by public action. ${ }^{374}$ Regulatory cues from the SEC created a framework within which private action to establish the ITS arose. Regulation ATS, meanwhile, appears to be producing some success in connecting trading systems, even beyond its formal requirements, by having set in motion a process toward that goal. The lesson of these cases for transitional states, then, may be the utility of legal cues as a means to facilitate broader change.

\section{B. AUCTION VERSUS DEALER MARKETS}

Two distinct trading approaches are utilized in modern equities markets: order-driven (or auction) markets and quote-driven (or dealer) markets. In order-driven markets, brokers direct clients' buy and sell orders to a central location, where they are executed (at least in theory) without intervention by a dealer. ${ }^{375}$ An investor can either give his or her broker a market order, which the broker will execute at the best available price, or he or she can submit a limit order, which will be executed only at the limit price (or a better price) ${ }^{376}$ On such auction markets, investors pay a commission to their broker, but do not pay a market-maker's spread. ${ }^{377}$ Generally, transaction costs on auction markets are low and quality of information is high. ${ }^{378}$ Because of their large number of buyers and sellers, finally, auction markets are generally in a state of equilibrium, ${ }^{379}$ with all buyers and sellers acting as price-takers.

Quote-driven markets, conversely, rely on market-makers (i.e., professional dealers wlio post bids and offers indicating prices that they are

373. See id. at 769.

374. See Cox \& Michael, supra note 303, at 846-47. See also Mendelson \& Peake, supra note 3, at 447 (noting the SEC's reliance on private entities in executing the mandates of the 1975 SAA).

375. See Poser, supra note 108 , at 520.

376. See id. at $520-21$.

377. See id. at 521 .

378. See Robert Harris \& Thomas Jorde, Antitrust Market Definition: An Integrated Approach, 72 Cal. L. Rev. 3, 22 (1984).

379. See id. 
willing to pay and receive for a given security). ${ }^{380}$ All transactions pass through a professional dealer. ${ }^{381}$ Consequently, customers pay a broker's commission plus the market-maker's spread. ${ }^{382}$ In such markets, investors are assured that they can buy or sell at all times. In principle, competition among multiple market-makers ensures the investor that he or she is getting the best execution available in the market. ${ }^{383}$

Significant for our purposes is the relative incompatibility of auction and dealer markets. ${ }^{384}$ Linkage of the sort described above is necessarily difficult to construct across market types. ${ }^{385}$ Thus, the relevant trading data of each system comes in a form not readily processed or acted on by the other. ${ }^{386}$ At a minimum, heightened transaction costs can be expected to arise from any attempt to combine auction and dealer markets into a single effective network. Thus, the existence of both market types in the United States "bedeviled attempts at integrating ... exchanges and OTC markets" for decades. ${ }^{387}$

The choice of auction versus dealer markets consequently is a form of network-driven standard setting. As described above, a single standard is to be preferred in networked securities markets in order to facilitate network compatibility and size, and hence, efficiency. ${ }^{388}$ However, whether at the outset, in efforts at market creation, or in later efforts at market restructuring, network effect barriers may stymie the efficient emergence of a common standard. ${ }^{389}$ Thus, efforts at 'market creation in transitional states can expect to face inefficient barriers to entry or excess competition, while attempts at market restructuring in developed

380. See Poser, supra note 108, at 519.

381. See id. at 519-20.

382. See id. at 520 .

383. See id.

384. See Karmel, supra note 220 , at 3 (describing auction and dealer systems as "inherently incompatible"). See also Schizer, supra note 43, at 1554 (noting the need for regulators to choose between auction and dealer structure).

385. See Poser, supra note 108, at 523 ("The fact that the quote-driven Nasdaq is basically incompatible with the order-driven trading systems of the major European exchanges is likely to create difficulties for Nasdaq in its efforts to establish a link with European trading systems."). See also Simon \& Colby, supra note 263 , at $86-87$ (stating that, notwithstanding growing compatibility between auction and dealer markets, "the primary structural difference between the markets remains").

386. See Bernard, supra note 350 , at 331. Additionally, the two types of market systems can be expected to prefer distinct degrees of such linkage. See Randolph James Amaro, Jr., European Union Regulation of Electronic Communication Networks: Stifling Global Integration of Securities Markets, 20 WIS. 1NT'L L.J. 397, 408 (2002).

387. See Bernard, supra note 350 , at 331 .

388. See supra Part II.B.

389. See supra Part II.B. 
economies may be stymied by the unwillingness of system sponsors to commit themselves to transition to the opposing standard, given the force of network lock-in and the uncertain outcome of network competition.

In such circumstances, the SEC and other securities market regulators may find that regulatory cues serve a useful function in facilitating either the creation of, or the adjustment to, a common market structure, whether of the auction or dealer market variety. Thus, market regulators might consider cues that favor a particular market type, or, less starkly, that outline the benefits and various means of achieving compatibility, in seeking to overcome network barriers to efficient transition to an auction or a dealer market. Investors in market microstructure, as well as brokers and dealers, can be expected to alter their allocation of resources and handling of orders to align with the implied expectations contained in such cues.

In Russia, for example, the emergence of a relatively effective quotedriven market structure awaited action by the Federal Commission on the Security Market. Once the Commission acted to provide technical assistance to the efforts of a particular group of broker-dealers to create a screen-based dealer system, and to designate that group as Russia's first recognized SRO, a rapid and largely beneficial shift to the RTS occurred. ${ }^{390}$ Brokers and dealers joined and directed their trades to the RTS, largely abandoning the fragmented exchange system they had relied on to date. Issuers, likewise, began to redirect their resources from Russia's floor exchanges to the RTS.

In addition to the technical assistance and indirect sanctioning of the Russian case, other regulatory cues directed to the choice of an auction or dealer market structure are available to securities market regulators faced with the need for transition. The government's role as market participant may be especially significant. To similar effect, information dissemination-and hence, the expansion of common knowledge-of the sort that occurred in the National Market System effort might also play an important role. Such information can be expected to facilitate a closer alignment of expectations among the array of relevant brokers and dealers, as well as issuers and secondary service providers, thereby increasing the speed and even likelihood of an efficient transition to a common trading system. This may be an especially useful tool in emerging markets, where inexperience is a central obstacle to efficient transition.

390. See Ahdieh, supra note 6, at 312-13. 


\section{CONTINUOUS Versus Periodic TRADING}

A final issue of network-related market microstructure likely to be influenced by effective regulatory cues is the choice of continuous versus periodic trading. ${ }^{391}$ These approaches essentially differ in the pattern of trading they permit. Under the continuous trading system, trades can be executed at any time during the operating hours of the market. ${ }^{392}$ This approach is beneficial for markets with active trading volume, as it allows investors to trade instantaneously without incurring downtime costs. ${ }^{393}$ Further, it empowers traders with the ability to instantaneously check pricing information and permits the market to continuously update pricing in response to new information regarding individual securities. ${ }^{394}$

In the periodic or call trading approach, on the other hand, trades are permitted only at certain predefined intervals throughout the day. ${ }^{395}$ This system operates through a process of "calling" stocks for a few minutes per day. During this time, brokers representing individual investors attempt to match the buy and sell orders that are currently active. ${ }^{396}$

While the continuous trading system is advantageous in markets that experience active trading, the periodic trading structure is better suited to markets with light or sporadic trading volume. ${ }^{397}$ In an active trading market, the periodic system is unduly restrictive because it burdens investors with substantial downtime costs as they idly await the next call. ${ }^{398}$ Periodic trading also is incompatible with high volume markets, as it permits price adjustments to be made only at preset junctures, leaving the market vulnerable to drastic price swings in either direction. ${ }^{399}$

Conversely, in markets with light trading volume, this structural choice has substantial advantages. ${ }^{400}$ Periodic trading structures have thus been especially successful in low-trading volume markets, for they require less resources to be maintained than their counterpart, ${ }^{401}$ they are

391. This approach has also been referred to as "call trading." See Beny, supra note 295, at 404.

392. See id.

393. See id. at 405 .

394. See id.

395. See id. at 404. See also LAWRENCE E. HARRIS, LIQUIDITY, TRADING RULES, AND ElECTRONIC TRADING SYSTEMS 27 (1990).

396. See Poser, supra note 108, at 518-19.

397. See Beny, supra note 295, at 405; Poser, supra note 108, at 519.

398. See Beny, supra note 295 , at 405 .

399. See id.

400. See generally id. at 404-05; Poser, supra note 108, at 518-19.

401. See Beny, supra note 295, at 405-06. Many markets that handle a lower daily volume of trades utilize this approach so that investors may reap the rewards of the substantially lower 
potentially a "superior method for addressing asymmetric information," 402 and they are arguably more resistant to substantial downturns in securities markets. ${ }^{403}$ In addition, periodic trading maximizes liquidity by compressing all trading into a short period of time. ${ }^{404}$ This option is also attractive with regard to assets that are indexed, as these securities are not traded based on new information and therefore raise little need for the higher trading costs associated with a continuous market. ${ }^{405}$ Instead, institutional investors with substantial index holdings seek primarily to minimize execution costs. ${ }^{406}$

The question of network compatibility is again evident in the choice of continuous versus periodic markets. While not completely incompatible, the gains from inter-network trade are unlikely to be maximized across such markets. As with auction and dealer markets, the data product of each market type is not readily made compatible with that of the other.

For this reason, network effects can be expected to favor some degree of convergence. It may therefore be unsurprising that many periodic markets are currently reorganizing themselves as continuous trading systems. ${ }^{407}$ Network obstacles to efficient transition at least sometimes may prevent the effective choice of a continuous or periodic system, however, and may slow the efficient transition of markets in one direction or the other.

In this light, the need for directed regulatory cues may again be an important lesson of the application of cueing theory in market transition. In the various forms utilized in the analogous choice of an auction versus dealer market orientation, ${ }^{408}$ such regulatory cues can help to facilitate

transactional costs associated with this structural setup. See Paul D. Cohen, Securities Trading via the Internet, 4 STAN. J.L. BUS. \& FIN. 1,3 n.6 (1999).

402. See Beny, supra note 295 , at 405 ("'A] call auction market may be a superior method for addressing asymmetric information: 'by imposing delay, [it] may be a mechanism that forces information traders to reveal, through their order placements, the existence of information."') (quoting Hans R. Stoll, Alternative Views of Market Making, in MARKET MAKING AND THE CHANGING STRUCTURE OF THE SECURITIES INDUSTRIES 67, 72 (Yakov Amihud et al. eds., 1985)).

403. See Richard Roll, The International Crash of October I987, FIN. ANALYSTS J., Sept.-Oct. 1988 , at $19,32-33$.

404. See Poser, supra note 108 , at 518.

405. See Beny, supra note 295, at 406; Mendelson \& Peake, supra note 3, at 458.

406. See Beny, supra note 295, at 406; Mendelson \& Peake, supra note 3, at 459 . It is important to note that, although both have significant advantages, the majority of equity markets, both domestic and international, currently employ continuous trading structures. See Beny, supra note 295, at 406.

407. See Beny, supra note 295 , at 406 . This pattern may give rise to particularly difficult challenges for regulators in transitional states, given the appeal of periodic trading in emerging markets.

408. See supra Part VI.B. 
efficient market transition toward either a periodic or continuous trading system. Particularly in the emergence of new equity securities markets, a cueing contribution in this regard may be essential.

\section{SECURITIES MARKETS VERSUS BANKS: FIRST QUESTIONS OF MARKET STRUCTURE}

A final issue of market structure that warrants notice, though one of somewhat different proportions than the questions of market microstructure discussed above, ${ }^{409}$ is the preliminary choice of whether a market should primarily, or exclusively, rely on the banking industry or on public securities markets to provide necessary corporate finance. The function of facilitating capital flows from savings to corporate investment can, of course, be served by either a commercial banking industry or a public securities market.

In the bank-dominated system, commercial banks control the capitalraising process. ${ }^{410}$ Thus, companies do not look to public markets for the majority of their capital needs. The bank-dominated system is consequently characterized by underdeveloped public debt (including reduced use of bonds or commercial paper) and a lack of equity offerings. $^{411}$

Securities-dominated systems have generally been seen as more receptive to capital needs; particularly those of less established corporate entities. ${ }^{412}$ Securities-based systems, however, involve greater investor risk and may be prone to some "unseemly competition for funds," which some believe may produce an optimal allocation of capital. ${ }^{413}$ Securities-based systems may also lack some of the monitoring benefits of bank-based systems. ${ }^{414}$

In this case, as with the examples above, we face a network-based dimension of incompatibility. Although a combination of the two systems might nominally seem preferable, experience suggests it is not necessarily feasible. $^{415}$ At a minimum, it may not be feasible in emerging markets,

409. See supra note 13.

410. See J. Robert Brown, Jr., Of Brokers, Banks and the Case for Regulatory Intervention in the Russian Securities Markets, 32 STAN. J. INT'L L. 185, 216 (1996).

411. See id.

412. See id. at I86.

4I3. See id.

414. See id.

415. See id. at 187. According to Brown, In the United States, banks grew increasingly dominant in the underwriting process until the intervention of the Glass-Steagall Act. In Great Britain, both custom and the rules of the 
where strong public securities markets do not already exist. "Since the capital-raising process is likely to be dominated by one class of institutions, developing countries should implement policies designed to promote the class of intermediary most able to meet their respective needs."416 Thus, a strong banking industry source of corporate financing may stymie the development of strong securities markets. ${ }^{417}$ This is what has occurred in Russia. ${ }^{418}$

Such a pattern can be understood in network terms. While the efficacy of public securities markets as a source of corporate finance depends on network size, banks are not similarly limited. They do not rely on network economies of scale. As such, the network barriers to entry and other network inefficiencies described above may produce competitive advantages for a bank financing model, without regard to whether a functioning securities market might otherwise be pareto efficient. Potential issuers in emerging markets may thus look to banks or utilize internal financing schemes (e.g., pension funds) for corporate financing. Institutional investors, meanwhile, may direct their resources to the acquisition of dominant stakes in potential targets. Absent some coordination between potential issuers and investors, strong securities markets may never emerge.

Cueing theory therefore counsels transitional states against too complete a reliance on market forces to resolve efficiently the choice between a bank-dominated or public securities market system. Instead, regulatory cues may again have a role. ${ }^{419}$ Most broadly, relevant cues in this case may be in the nature of Cooper's "confidence building measures." 420 Thus, greater confidence in the prospects for macroeconomic stability and growth-confidence encouraged by state action-can be expected to translate into a greater willingness to undertake

stock exchange kept commercial banks out of the share distribution process. Once these limitations were removed, however, commercial banks largely absorbed the class of entities responsible for corporate underwriting.

Id. (internal footnotes omitted).

416. Id.

417. See id. at 187-88. Closer to home, the long-standing restrictions of the Glass-Steagall Act, now lifted, were grounded in some similar notion of potential bank dominance. See Glass-Steagall Act, 48 Stat. 162 (1933), repealed by Gramm-Leach-Bliley Act, Pub. L. No. 106-102, § 101, 113 Stat. 1338 , 1341 (2001); Jolina C. Cuaresma, The Gramm-Leach-Bliley Act, 17 BERKELEY TECH. L.J. 497, 498 502 (2002) (discussing the passage and eventual repeal of the Glass-Steagall Act).

418. See Brown, supra note 410 , at $250-53$.

419. See id. at 186-88 (suggesting that the Russian government should intervene with affirmative government policies to restrict a bank-dominated securities system).

420. See supra notes $146-50$ and accompanying text. 
the risks of equity investment and a consequent strengthening of public securities markets. State entities responsible for interest rates and monetary policy, whether central banks or a U.S.-style reserve bank, as well as executive and legislative agencies with a hand in fiscal policy, can use the various mechanisms in their power to encourage such stabihty and growth.

Other potential cues might also be considered. To begin with, government reliance on securities markets as a market participant-as in the investment of public funds such as the Social Security Trust Fundmight be considered an important cue in facilitating the broad-based coordination necessary to produce strong securities markets. ${ }^{421}$ Another potentially useful regulatory cue to consider is technical assistance funds directed to securities markets, which have played an important role in securities market development in recent years. ${ }^{422}$ Finally, considering Bernard Black's elaboration of the legal and institutional preconditions to strong securities markets, one might cite development of the legal system generally as an important cue favoring strong securities markets. ${ }^{423}$ Since securities markets are more dependent on the existence of such preconditions than are banks, development of the latter can be expected to help facilitate the coordination equilibrium of securities market development over a default reliance on banks.

When such cues can effectively signal expectations regarding the further development of public securities markets, relevant network barriers may more effectively be overcome. Such cues may therefore be essential to ensure that a strong securities market structure emerges in new markets.

$$
* * *
$$

What does a cueing theory add up to, then, in the creation of strong securities markets? How does its prescription for potential new markets, where the need is clearest, compare with notions of the role of law in securities market transition? By way of response, a fruitful contrast can be drawn between the implications of cueing theory for two of the most

421. See Ahdieh, supra note 6, at 343. Conversely, transitional governments must exercise caution not to undermine public securities markets through their market participant function. This might be argued to have been the case in Russia, where incredibly high rates of return on government debt drew investors from securities markets to banks, which in turn held most of that debt. See id. at 344.

422. See id. at 345 .

423. See generally Bernard S. Black, The Legal and Institutional Preconditions for Strong Securities Markets, 48 UCLA L. REV. 781 (2001) (exploring which laws and related institutions are essential for developing strong securitics markets). 
important analyses of the role of law in securities market transitionnamely, those of John Coffee and Bernard Black..$^{424}$

In essence, Coffee challenges recent assertions that "law matters" in securities market transition. ${ }^{425}$ Coffee attempts to turn this conclusion on its head by means of a historical analysis of the patterns of securities market development in the United States, the United Kingdom, France, and Germany. ${ }^{426}$ Based on the experiences of the United States and the United Kingdom, Coffee concludes that the "law" that matters in the creation of strong securities markets is not public law protection of minority investors, but private bonding and analogous norms, which can more effectively provide such protection. ${ }^{427}$ As for law itself, Coffee concludes that it most effectively facilitates the emergence of strong securities markets when it stays in the background and thereby encourages the development of the private law he favors. ${ }^{428}$

Without disputing Coffee's identification of private law as an adequate, if not preferable, source of investor protection, or the ensuing conclusion that state regulation should not intervene to impose such protections, cueing theory suggests an entirely different role for law in efficient market transition. Even if law is unnecessary, if not harmful, in achieving an adequate protection of minority investors, Coffee's historical evidence is indeterminate of whether law might have some alternative role to play in the creation of strong securities markets. ${ }^{429}$ Specifically, it does not resolve the potential importance of regulatory engagement in overcoming network-based coordination failures in securities market transition.

For emerging markets, then, the proposed cueing theory counsels against too wholesale an adoption of Coffee's prescriptions. Extensive regulatory intervention, as Coffee outlines in France and Germany, may well be ill-advised. On the other hand, careful regulatory cues that are designed to coordinate the expectations of potential and fledgling corporations, investors, market professionals, and market sponsors, and

424. Compare Coffee, supra note 2 (arguing that the emergence of strong securities markets may not require a comprehensive legal foundation), with Black, supra note 423 (arguing that a country's laws and institutions are two essential prerequisites for developing strong public securities markets).

425. See Ahdieh, supra note 6, at 324.

426. See Coffee, supra note 2 , at 7 .

427. See id. at 8-10,60. See also Ahdieh, supra note 6, at 324.

428. See Coffee, supra note 2, at 9-10,52. See also Ahdieh, supra note 6, at 325.

429. See Ahdieh, supra note 6 , at 325 . 
which thereby encourage the market through its earliest phases of development, may be essential.

What of Black's teachings for emerging markets, spanning from Russia to Korea ? $^{430}$ Black has emphasized the centrality of two elements in the creation of strong securities markets in developing economies. He first refers to mechanisms that ensure that minority shareholders receive "good information about the value of a company's business"; second, he discusses the need to assure those shareholders "that the company's insiders (its managers and controlling shareholders) won't cheat investors out of most or all of the value of their investment through 'self-dealing' transactions ... or even outright theft." "43! Although Black's prerequisites, unlike Coffee's analysis, are all but impossible to dispute, cueing theory nonetheless posits that there may be more to be done. With these institutional elements alone, network barriers may continue to stymie efficient patterns of market entry, modernization, and linkage.

Emerging market regulators charged with facilitating the transition to strong securities markets must also be cognizant of these coordination barriers to transition and be prepared to act against them. Stating the case more strongly, cueing theory challenges an exclusive emphasis on the protection of minority investors as the central barrier to strong securities markets in developing economies. ${ }^{432}$ Rather, network effect barriers may also be significant and require regulatory intervention.

Yet cueing theory does not challenge the admonition to securities regulators to minimize regulatory interference, let alone prescribe command-and-control regulation of new markets. Rather, it presses the possible need for constrained regulatory cues, designed to overcome those barriers to efficient market creation that may arise in any particular case.

\section{CONCLUSION}

Building on a corner of game theory not familiar to the mainstream legal literature and on what I have previously characterized as the network character of securities markets, this Article articulates a model for

430. See generally Bernard Black, Corporate Governance in Korea at the Millennium: Enhancing International Competitiveness, 26 J. CORP. L. 537 (2001) (discussing his May 2000 Report to the Ministry of Justice of the Republic of Korea regarding South Korea's corporate governance system and his recommended legal reforms); Black, supra note 423.

431. Black, supra note 423 , at 783.

432. See id. (explaining that law provides confidence to minority investors by informing them that they will not be cheated, and describing this provision as an "essential prerequisite[]" to strong public securities markets). 
understanding the nature of securities market transition and, more specifically, law's role in that process. In a form I have termed "regulatory cueing," law appears to have a central but unfamiliar role to play in the creation and restructuring of securities markets, whether in the emerging economy of Russia or the established one of the United States. Specifically, regulatory cues can serve a focal point function in coordinating the expectations of securities market participants, thereby alleviating potential network barriers to efficient transition. Arising from the coordination game character of market transition, such a cueing function encompasses unique informational, facilitative, and encouragement functions for law.

A cueing theory of law in securities market transition constitutes a significant addition to ordinary conceptions of what constitutes the discipline and practice of securities regulation. More broadly, a cueing theory of law extends traditional understandings of what law does by its distinctive emphasis on shaping individual expectations, rather than incentives, by its intertwining of public and private regulatory roles, and by its nonreliance on coercive sanction (conventionally seen as law's seminal trait).

This analysis contributes to growing bodies of scholarship on private regulation, social norms, and expressive law. Further, it adds to the law and economics literature by developing a close application of game theory to the increasingly important study of network effects and their regulatory implications, and, perhaps most significantly, by extending game theoretic analysis to securities regulation and administrative law more broadly, where it has found limited application to date.

The ultimate reach of a cueing theory of law extends well beyond securities markets. Most immediately, it speaks to law and policy in network industries generally, including telecommunications, the Internet, and other emerging technologies. Law's cueing function may have a particularly central role in network-driven standard setting, whether in interstate transportation, electricity transmission, electronic data transfer, wireless communication, or instant messaging. In this increasingly important area of social and economic policy, cueing theory may help to provide a clearer definition of the respective roles of public and private regulation, and may serve as a mechanism of efficient standardization. In the broadest terms, finally, cueing theory's lessons may reach even beyond network industries to other cases of missing markets and to monopoly regulation generally. In such environments, regulatory cues may have an important role to play in the creation of vibrant markets. 